\title{
Public Land Management Values: A Delphi Study of Austrian and Pacific Northwest United States Recreation Resource Managers
}

Jessie Meybin

West Virginia University

Follow this and additional works at: https://researchrepository.wvu.edu/etd

\section{Recommended Citation}

Meybin, Jessie, "Public Land Management Values: A Delphi Study of Austrian and Pacific Northwest United States Recreation Resource Managers" (2012). Graduate Theses, Dissertations, and Problem Reports. 3543.

https://researchrepository.wvu.edu/etd/3543

This Thesis is protected by copyright and/or related rights. It has been brought to you by the The Research Repository @WVU with permission from the rights-holder(s). You are free to use this Thesis in any way that is permitted by the copyright and related rights legislation that applies to your use. For other uses you must obtain permission from the rights-holder(s) directly, unless additional rights are indicated by a Creative Commons license in the record and/ or on the work itself. This Thesis has been accepted for inclusion in WVU Graduate Theses, Dissertations, and Problem Reports collection by an authorized administrator of The Research Repository @ WVU. For more information, please contact researchrepository@mail.wvu.edu. 
Public Land Management Values: A Delphi Study of Austrian and Pacific Northwest United States Recreation Resource Managers

\author{
Jessie Meybin
}

\begin{abstract}
Thesis submitted to the
Davis College of Agriculture, Natural Resources and Design,

Division of Forestry and Natural Resources at West Virginia University in partial fulfillment of the requirements

for the degree of
\end{abstract}

\author{
Masters of Science \\ in \\ Recreation, Parks and Tourism Resources \\ Dr. Robert Burns, Committee Chairperson \\ Dr. David Smaldone \\ Dr. Steve Selin \\ Dr. Arne Arnberger (adjunct WVU Faculty) \\ WVU Davis College: Division of Forestry
}
Morgantown, West Virginia
2012

Keywords: Delphi Method, Social Carrying Capacity, Public Recreation Management, International Collaboration

Copyright 2012 Jessie Meybin 


\section{ABSTRACT \\ Public Land Management Values: A Delphi Study of Austrian and Pacific Northwest United States Recreation Resource Managers}

\section{Jessie Meybin}

There is a continuing global increase in recreational visitor use of public land. This rise in visitation can be a good thing if a proactive management plan utilizing strong methodology to anticipate impacts to an area and sustain its natural and social resources is in place. Although a wide spectrum of issues is presented to each management, few of the concepts are new to any of the administrators. With increasing duties, newly emerging concerns, and decreasing time, there is little room or patience for error concerning the implementation of any management derivatives or techniques. If the existing research on all these policies and frameworks was made widely accessible, and some system for deciphering the level of their most universal relativity was reached for collaborative purposes, it would maximize the support system for the managers, thereby minimizing the guesswork and maximizing the efficiency of their plan. A Delphi study was conducted in 2010 to identify possible levels-or aspects of the management decision-making process-on which managers could effectively communicate details of the implementation of their techniques to international colleagues. Managers from protected areas in Austria and the Pacific-Northwest division of the US Forest Service were asked a series of questions about their area management plans pertaining to both biological and social sustainability. Once the frameworks or systems were broken down into the universal management concepts of values and actions, the idea of collaboration upon that level was presented to the participants to assess their willingness to participate in such studies. Regardless of the multitude or strength of the widereaching benefits that would be provided by any future collaborative efforts, it is the managers' active involvement that will ultimately determine the strength, relevance, and outcome of any future studies. 


\section{Acknowledgements}

First, I would like to thank my loving parents, who made my whole education possible, and also provided the emotional education and support that enabled me to get through it with my sanity intact. I am extremely grateful to Dr. Robert Burns, for selecting me to be a part of the Davis College graduate program, and providing the experience of investigating the formation of an international exchange program by letting me loose in such an awesome place for the summer. My heart has been eternally warmed by the welcome I received from so many people and places I know hold dear in Austria. A special thank you to Dr. Arne Arnberger for the Viennese hospitality and also for being such a helpful, friendly resource during my time in Austria. I would also like to personally thank the staff of the Dürnstein Wilderness Area, National Park Gesäuse, National Park Thayatal, and the townsfolk of Merkersdorf and Hardegg for really making my visits amazing by your enthusiasm toward helping with my research and guiding me around your gorgeous surroundings. I'd also like to thank all of the managers of the study, but most importantly those that continued their participation until the end. I appreciate the time, attention and continuous support of my committee members, Dr. Arnberger, Dr. Burns, Dr. Steve Selin, and Dr. Dave Smaldone. I am very grateful to the professors Dr. Smaldone and Michael Strager at WVU that gave me extra help when it was not their responsibility. Lastly, but most certainly not least, I would like to thank everyone who helped, housed, fed and encouraged me at any time during the many drafts of this document. 


\section{Table of Contents}

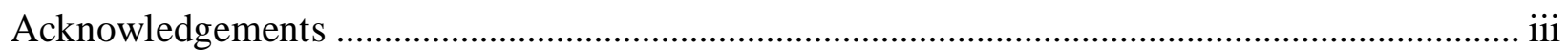

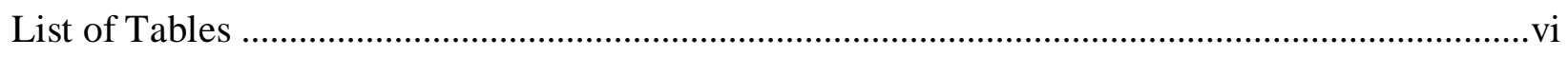

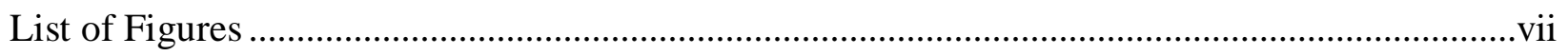

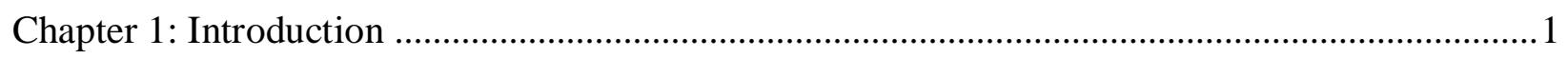

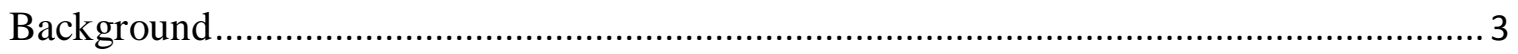

U.S. recreation management origins and research progression ........................... 4

Austrian recreation management origins and research progression. ..................... 6

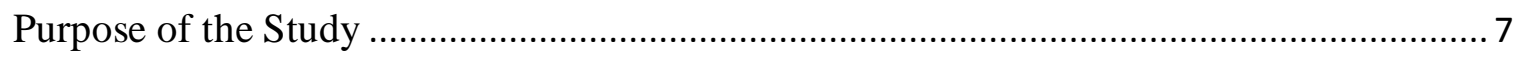

Chapter 2: Review of the Literature ….............................................................................. 9

Social Carrying Capacity, Crowding and Conflict ..................................................... 11

Visitor Use Impact on the Environment …............................................................. 15

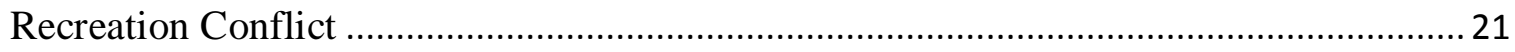

Techniques Regulating or Manipulating Visitor Use .............................................. 26

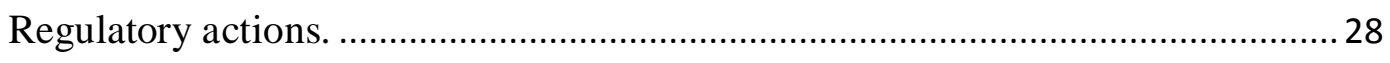

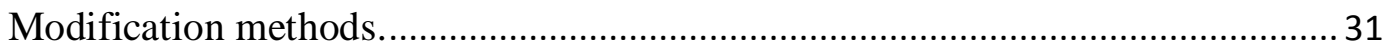

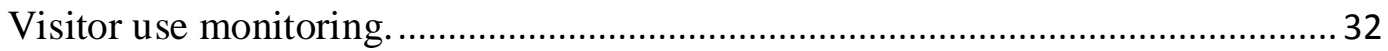

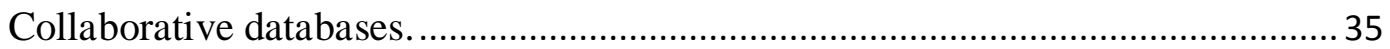

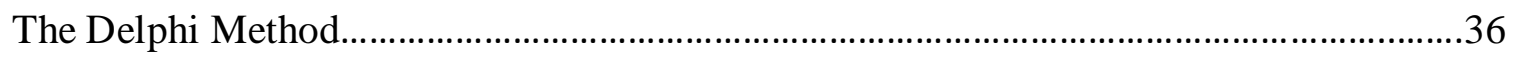

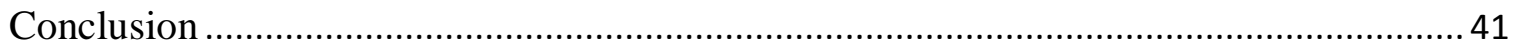

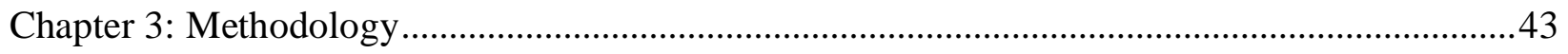

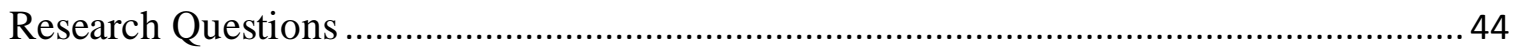

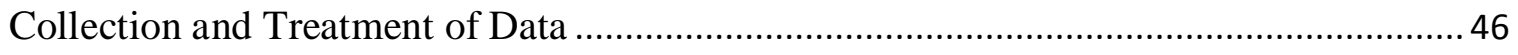

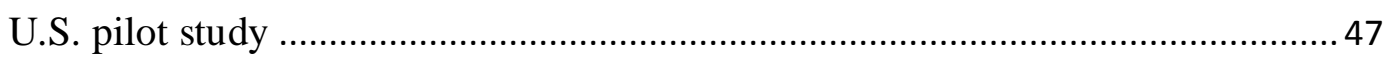

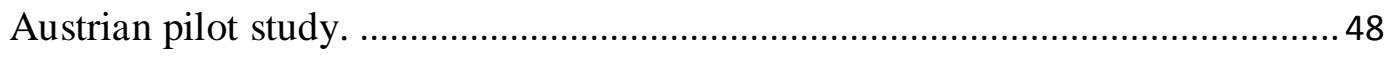




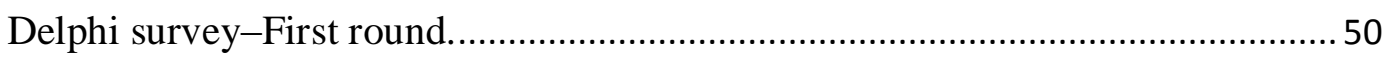

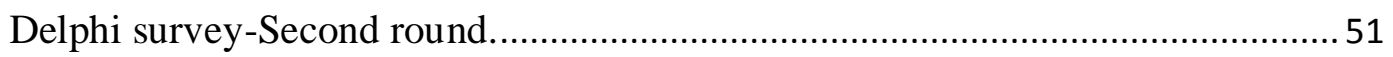

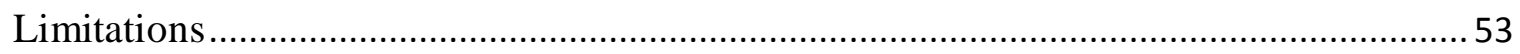

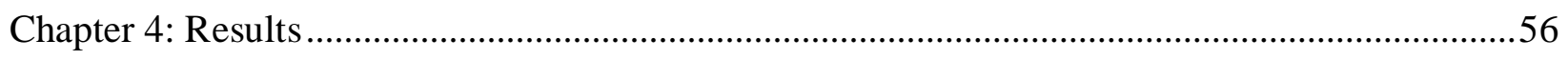

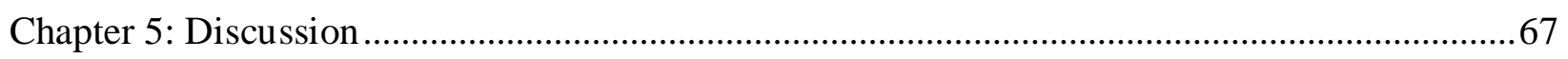

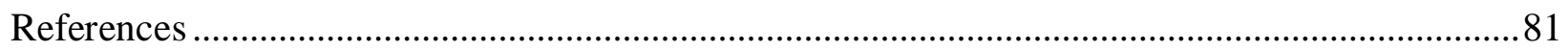

Appendix A. Pilot Research Instrument for USFS Special Use Permit (SUP) Study ................100

Appendix B. Pilot Research Instrument Incorporating Austrian Managers into Study ..............101

Appendix C. Delphi Research Instrument: First Round ..................................................... 102

Appendix D. Delphi Research Instrument: Second Round .................................................... 104

Appendix E. English Summary Preceding Second Round Delphi Survey Instrument ..............110

Appendix F. German Summary Preceding Second Round Delphi Survey Instrument ..............112

Appendix G. Introductory Email for Austrian Participants .................................................. 114

Appendix H. Introductory Email for U.S. Participants .......................................................115

Appendix I. Example of a Reminder Email for Non-Respondents .........................................116 


\section{List of Tables}

Table 1 Methods Available for Visitor Counting..................................................... 29

Table 2 Participating Areas........................................................................... 45

Table 3 Regular Visitor Activities.................................................................... 57

Table $4 \quad$ Recreation Conflict.............................................................................. 57

Table $5 \quad$ Understanding Visitor Use................................................................... 58

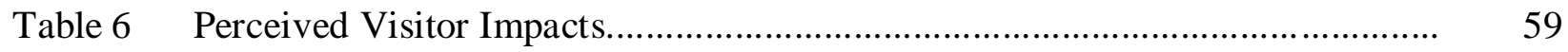

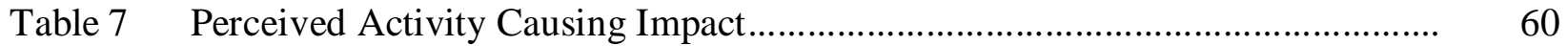

Table 8 Visitor Management Frameworks.......................................................

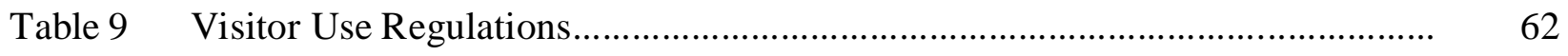

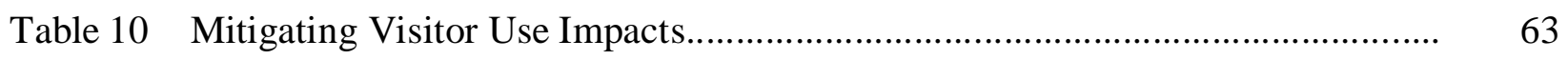

Table 11 Acquiring Knowledge of Other Visitor Management Frameworks................... 64

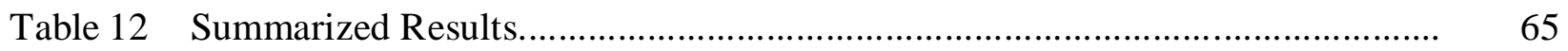




\section{List of Figures}

Figure 1 Public Recreation Land Resource Management Objectives........................... 11

Figure 2 Integrated Carrying Capacity Studies Diagram........................................ 16

Figure 3 Satisfaction Level as an Indicator of Behavioral Response............................ 25

Figure 4 Identifying and Monitoring Indicator Variables....................................... 33

Figure 5 Research Process and Literature Review Model......................................... 43 


\section{Chapter 1: Introduction}

Regardless of what climate, culture, or other location-specific challenges an area management has to deal with, most are working toward the same generalized goal: the sustainability of an areas' resources. In order to ensure this sustainability, the resources and the maximum acceptable level of human use must be defined and balanced in a way that is measurable and ongoing (Hennig \& Laube, 2006; Muhar, Arnberger \& Brandenburg, 2002; Rutherford, 1998; Shelby \& Vaske, 1991). The factors or conditions that have been defined as the ideal state are vulnerable to future influences and must be monitored over time to ensure the continuous sustainability of an area's resources.

Just as department store managers scrutinize the shelves of their stores and make sure there is enough stock available to meet their customers' demands, public land managers worldwide must monitor the inventory of their natural and social resources in anticipation of public demand. The inventory for land managers however, is clearly more abstract and can, be more difficult to obtain. The expectations of user groups, who may have much more specific needs than the general population, must also be taken into consideration. Department store management teams use some of the same products and methods to create and monitor inventories, thereby enabling their chains of stores to communicate and thrive by utilizing a standardized support system. The immeasurable differences in resource types and usess of land areas makes the standardized use of one method for all virtually impossible. Many of the difficulties that minimize or prohibit communication between area managers can be traced to the fact that they are at different stages of a process, or using alternate processes within their framework or plan, even if they follow the same policies. Every individual area has its own identity, composed of its own virtual inventory of resources, regardless of the agency(s) with 
which it is associated. Different processes and progress speeds are common among managements in public recreation areas, because each area's management has to deal with a unique mixture of issues, users, resources, and other conditions that comprise the identity of a land area.

There are many different frameworks and methodologies used to various extents by area managers to measure and achieve the ideal conditions or standards they wish to sustain (Manning, Lime, Freimund, \& Pitt, 1996; Getzner, 2003; Manning, Shelby, \& Vaske, 1991; Hendee et al, 1968). Mechanisms such as resource capacity analyses and needs assessments are not agency decisions subject to environmental analysis; but rather analytical tools that inform an agency decision (United States Department of Agriculture [USDA], 2008a). Although massive numbers of research studies exist, most remain unused because of the adaptation of more common and widely used frameworks, or the supposition that these on-site studies would be too complicated for implementation in any setting that is too different. The main goal of sustainability still drives all these different frameworks or systems into use. Within each system there are actions, reactions, and conflicts that might be site-specific, but are encountered at numerous sites. It is evident that there is a common ground for communication and support on this level of values or desired conditions, as well as enough benefits for all parties involved to justify their participation. Creative ways must be found to communicate what does and does not work for different area types. Many different areas share the same values, even though they might be prioritized or worded differently within their stated goals. These common values, such as providing benefit to local communities and preservation of natural habitats, could serve as a foundation upon which recreation managers using different frameworks could effectively communicate and address similar issues to adapt subsequently to their unique situations. 
This study used two rounds of the Delphi process to elicit the opinions of experts on a topic-in this case, public land managers in charge of recreation matters. The Delphi method selected for use because it allows the incorporation of the details of an individual's implied meaning into the analysis of the answers. This enabled the author to develop a deeper understanding of the conveyed concepts and recognize when different descriptions with the same meaning are used. The three objectives of this empirical Delphi study were to: (a) identify these common values, similar issues, and decisions about managing them, (b) make observations as to how and why any common values are prioritized differently between the areas and countries, and (3) gauge their level of enthusiasm for collaborative research on a local and international scale by asking for their perceptions of possible benefits or constraints.

\section{Background}

This study emerged in response to the United States Forest Service (USFS) releasing the Final Derivatives for Forest Service Outfitting and Guiding Special Use Permits (SUP) in September of 2008 (USDA, 2008a). Efforts were made on a regional level to educate Forest Service managers about effectively implementing the new derivatives, as the changes could be impactful only if they are understood and put into practice by the managers. This study was initially proposed to gather the collective opinion of the regions' managers on the implementation of these new directions and intra-agency communication efforts.

At the International Symposium on Society and Resource Management (ISSRM, 2008) associates from the University of Natural Resources and Applied Sciences in Vienna (BOKU), University of Hannover in Germany (LUH), and West Virginia University (WVU) agreed on the importance of international research in the expanding recreation field, and began the discussions 
that developed into the Global Park Learning Program, an international exchange program developed to immerse students in the diverse world of visitor management in both the urban and rural parks of Austria and Germany. This study expanded by adding Austrian managers to the respondent group, broadening the span of research collected, and redirecting the objectives in order to investigate the managers' motivations for international collaboration in light of the upcoming educational programs that would disseminate policies in both countries. Please note the policies and histories cited in this study have been condensed to the information relevant to recreation management on public land.

U.S. recreation management origins and research progression. The concerns about industrialization and over-consumption of resources faced today are the same foreseen threats that brought the idea of delegating and conserving public land to life in the United States as far back as 1876. Public recreation in the US is provided nationwide by several federal agencies, including the National Park Service (NPS), the Fisheries and Wildlife Service (FWS), the Bureau of Land Management (BLM) and the National Forest Service (NFS). The US Forest Service is housed within the Department of Agriculture, while the National Park Service (NPS), Fisheries and Wildlife Service (FWS) and Bureau of Land Management (BLM) are in the Department of the Interior.

As early as 1911, the Weeks Act (Pub. L. No. 110-343, 36 Stat. 961) was established to designate land for the National Forest System. Since Teddy Roosevelt created the US Forest Service in 1905, the agency's main goal has been to "sustain healthy, diverse, and productive forests and grasslands for present and future generations" (US Forest Service, 2008, para. 1). This sentiment still motivates the many frameworks and policies active in the US Forests today, but an increase in use and dynamic development of Forest Service policies from the federal and 
site-specific level has led to the present stage in which more communication and standardization of some aspects are needed to maintain agency-wide efficiency.

Two recent examples of such communication efforts are: presentations given at some US Forests by regional managers to help administrators understand and implement new derivatives (USDA, 2008b), and the Forest Service Communication Plan which serves to inform and explain changes in the Federal Register to the outfitters, guiding services, and other parties that might be affected (Holbrook, McGee, Walsh, \& Schiff, 2008). US Forest Managers today are trained to operate under a centralized agency with a history of standard-issued policies. The earlier establishment of a national public land management system lent itself well to both agency-wide studies and research partnerships with scholastic institutions. This growing collection of studies on public land dynamics was used by the agency to handle the paradoxical task of creating uniform policies broad enough to retain relevance for each of its separate units while governing them as a single entity.

Recreation research in the US has consequently been focused on producing full frameworks, which are basically protocols and/or cycles of management objectives, techniques, and other components combined in such a way that they can be utilized in a range of situations, such as helping the individual US Forest managements adapt broader agency derivatives for implementation. In order to make appropriate comparisons between US and Austrian resource managers (whose National Park history is not yet 30-years old), we had to ask USFS managers to step back from FS policy and describe their implemented techniques as actions that uphold the values within agency and area policies. For example, the specific actions within or benefits from the SUP process were changed to visitor use techniques, such as limiting group size, informing visitors in advance, prohibiting off-trail use, and other more generalized actions. The complex 
systems these managers used when working within the agency made it difficult for some of them to break policies down into frameworks, systems, and other processes. It was also difficult for Austrian resource managers to categorize policies into specific actions that combat certain issues, because they have known, researched, and implemented them as units.

Austrian recreation management origins and research progression. Generally, Austrian resource managers built their management policies as individual units, and were answerable only to the governments of their secular provinces and localities. They also implemented guidelines to achieve or sustain their certification status with European or international conservation organizations, such as the World Tourism Organization (WTO) or the International Union for Conservation of Nature (IUCN). Compared to the US Forest Service managers, the Austrians operated under even broader policies, yet made their informed management decisions on more of a site-specific, issue-objective-action basis, as a result of the decentralized federal government.

Austria's oldest national park is the Corinthian section of the Hohe Tauern National Park, and was established in 1981. Because of the short history of Austrian public land management , little relevance was seen in implementing most existing management frameworks or any direct implementation of U.S. methodology. Culture and traditions in the various regions of the small but eclectic country are rooted deeply enough to have policies written to accommodate them. Conversely, the designation of public land in the US is a tradition unto itself, having been established for the greater part of the country's history.

Recreation in Austria and much of Europe is steeped strongly in traditions that cause managers to place a high degree of emphasis on prioritizing social use. Public land managers are eager to avoid making decisions that might potentially generate severe resentment from their 
area's surrounding public. While the USFS was established to protect the land by controlling commercial use, the Austrian parks have no commercial use at all, except for one rafting company in the Gesäuse National Park. A number of Austrian parks and protected areas were established in order to directly prevent area-damaging developments, such as a hydroelectric dam. This was the catalyst for the designation of both the Danube Floodplains National Park near Vienna and the Salzburg section of the Hohe Tauern National Park (Synge, 2004).

\section{Purpose of the Study}

The aim of the study was to understand differences in values related to visitor management between Austrian and US resource managers. The issue at hand is that there shas been little research or practical, manager-oriented technical reports or decision-making processes that are international in scope (Aikoh, Arnberger, Shoji \& Mieno, 2008; von Ruschkowski, Valdeig, Jakob \& Homann, 2008). The research was therefore divided into four categories: (1) social carrying capacity and crowding, (2) visitor use impacts on natural resources, (3) recreation user conflict, and (4) management practices/methods.

As population grows, so does recreational use of public land (Collins \& Brown 2007; Holdgate, 1984; ICUN, 1982; Watson, Cole, Turner, \& Reynolds, 2000). Although preserving public land is the primary reason for protection and management of a natural resource area, managers must not forget that the land is being preserved for the public and the use of future generations. The relationship with the public is not only a responsibility, but a source of

potential resources for an area's sustainability, both on public and private lands. Even when the ecological carrying capacity threshold has not been exceeded, if visitors encounter each other more than they expected, satisfaction levels may decrease. A drop in satisfaction levels or displacement of users usually indicates that the acceptable level of social carrying capacity 
(SCC) has been exceeded. Whether building a new program or renovating an existing plan, managers need to understand and be able to compare their informed decisions on different resources. Even though situational, structural, and cultural differences might alter the priority of values across different areas, the techniques that are used to identify values and determine what is most important should be standardized. Making research more universally understandable and relevant through standardization might lead to managers having: (a) a heightened awareness of existing studies, (b) a greater tendency for cooperative research, and, eventually, (c) more reliable results for maximum sustainability by reinforcing the methods used to balance social and ecological directives. 


\section{Chapter 2: Review of the Literature}

The first thought associated with the values of recreational activities in natural settings is the multitude of benefits received by visitors from the landscapes upon which they recreate. Research on benefits such as health and wellness, place attachment, aesthetic beauty, solitude, and interactions with wildlife is plentiful and wide-ranging in the US and worldwide (Daniel \& Boster, 1976; English, Kocis, Cordell, \& Green, 2006; McCormack \& O’Leary, 1995;

Schauman, 1988; Schroeder, Dwyer, Louviere, \& Anderson, 1990). However, the benefits these visitors seek can ultimately result in the degradation of the very resources they value. Visitors can physically or biologically negatively impact the wilderness they come to absorb. On a social level, visitors might negatively impact others' satisfaction levels because of their conflicting desires. An example of this might be the clash between those seeking fraternal adventures versus those who seek solitude in a pristine natural setting.

The term value for the managers of such public recreation settings becomes important. Resource managers' universal duty is to sustain the balance between the opportunities made available to their visitors and the measures needed to prevent those same visitors from depleting the natural integrity of the landscapes, ecosystems, or the experiences provided by the living landscape they protect. The idea of using values as a means of comparison between forest managers is not a new one. Studies in recent years have shown that research based on values can be efficient, and even indispensable, for initial wider-ranging studies (Bourke \& Luloff, 1994; Ferguson, 1996). The results of a mail survey carried out among Austrian forestry professionals showed that "the persons in charge of putting sustainable forest management into practical action can be characterized by specific value patterns" (Pregernig, 2001, p. 278). The US Forest 
Service recently drafted a recreation mission outlining the categories of values they work to uphold:

- $\quad$ provide (activities, experience, knowledge, features, local benefit)

- $\quad$ protect (wilderness, views, scenic, solitude)

- $\quad$ partner (communities, volunteers, private sector, locals)

- $\quad$ performance (legal requirements, responsibilities, strong research results). (USDA, 2008b)

These categorizations reveal how certain universal values and concepts can be gradually formed into indicators that are understood by all parties. The inter-relationship of such values is illustrated in Figure 1. In this study, the frameworks and policies of the two countries were dissimilar enough in their prioritization of these values that they had to be compared by the individual values themselves (e.g., social carrying capacity, ecological impact), followed by the techniques and frameworks upon which these values are structured.

\section{The Delphi Method}

In the literature review the origin and characteristics of the Delphi method will be described, and the legitimacy and purpose of using this method over other qualitative studies for this particular nature of research will be explained. The general goal of any application of the method is to achieve the results of a group problem-solving effort towards a complex problem without the confrontational variables of a group meeting. This can be done by consolidating the opinions of knowledgeable individuals through a research process. 


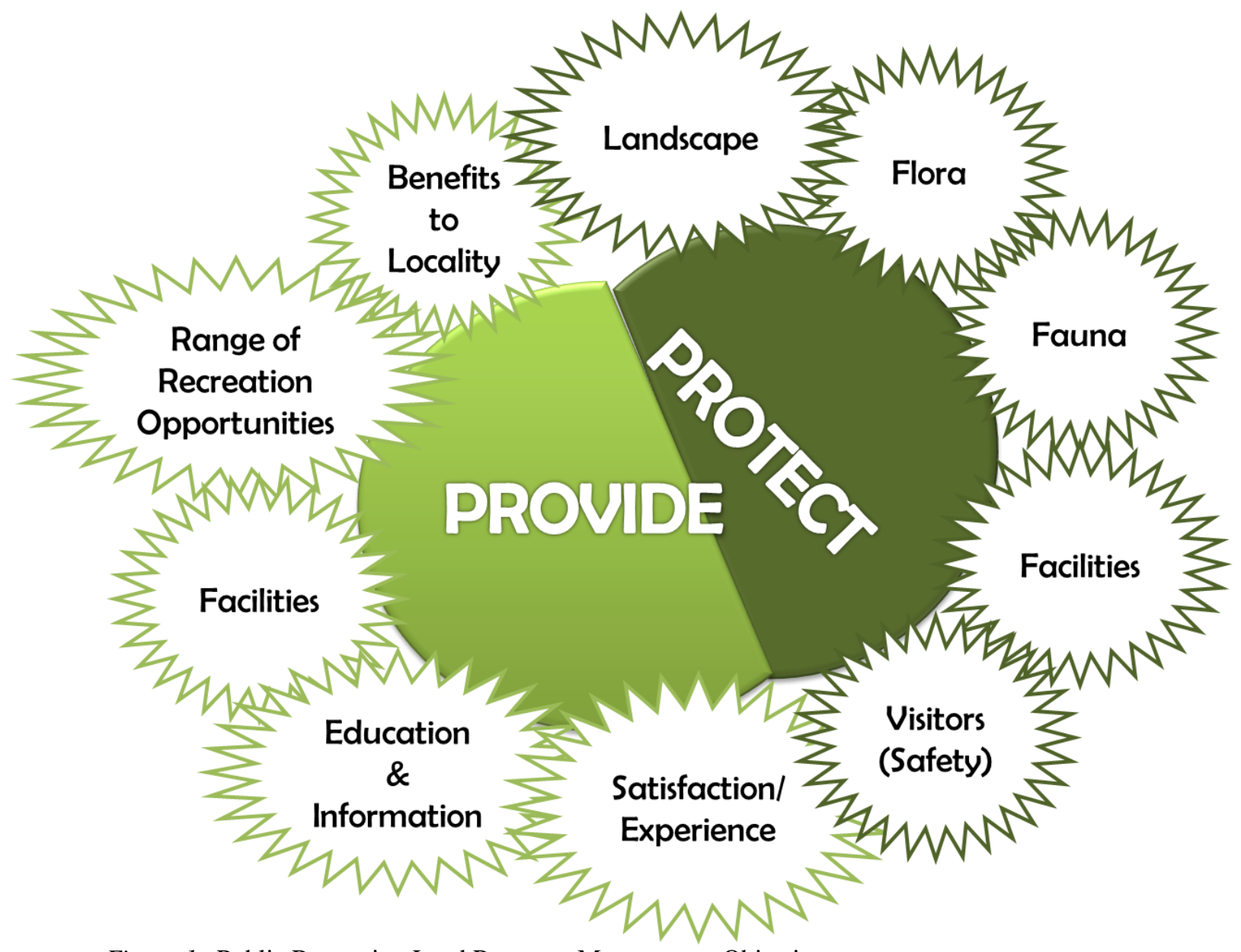

Figure 1. Public Recreation Land Resource Management Objectives.

\section{Social Carrying Capacity, Crowding and Conflict}

The importance of the social function of forests for recreation as a source of health and well-being, as well as for nature tourism, is increasingly recognized globally. Carrying capacity has different facets, but generally denotes the number of people a specified area can carry in an allotted amount of time before the area starts to deteriorate in one of many possible ways. The ecological impact is the aspect we think of first, but the social aspect of carrying capacity can be affected with or without an apparent ecological impact. Managers must consider users' resources of the area as well, since "nature can only be protected and advanced by man in a 
sustainable way if mankind considers itself to be a part of nature" (Mose \& Weixlbaumer, 2006, p. 152).

For this study, the term user base is defined as current and potential recreation users, members of local communities, and existing commercial partnerships. As human population increases, the number of protected area visitors continues to rise (Collins \& Brown, 2007; Holdgate, 1984; IUCN, 1994; Watson et al., 2000). This growing influx of people means more contact between visitors, which consequently leads to more user conflicts and a greater potential for overcrowding. These conditions can lead to negative impacts on the natural space, other visitors, and staff. This is likely to occur if dissatisfied users react negatively when their experience falls short of their expectations. It is essential for public recreation managers to know their user bases' social preferences and common traffic patterns in order to make sustainable decisions.

The most popular topic for social carrying capacity studies to date is the issue of crowding. Nearly every area management experiences crowding, whether it is a constant concern or only for certain time periods, areas, or types of users. It might become necessary to obtain capacities before determining use levels, because it is easier to present desired behaviors as norms at the start, and harder to correct behavior people are already displaying. Crowding is the relationship between the number of contacts and average user satisfaction. Perceived crowding depends on user values may vary by group, area, or country (Ditton, Fedler \& Graefe, 1983; Manning, 1999a). As a result managements must measure and account for known differences in user groups when planning to minimize conflicts.

Crowding has been studied in various capacities and conditions for the last four decades in the US There have been many studies on the conditions, such as location, that might cause a 
feeling of crowding (Becker, Niemann, \& Gates, 1981; Ditton et al., 1983; Heywood, 1993;

Manning, Lime, \& Hof, 1996; Tarrant, Cordell, \& Kibler, 1997;). Crowding has been the topic of several comparative analyses (Altman, 1978; Baum \& Epstein, 1978; Shelby, Vaske, \& Heberlein, 1989). Most of the Austrian studies on social dynamics of public recreation seek data on visitor patterns and behavior, rather than use levels and density. Accordingly, the notion of crowding is often neglected in much of this effort (Arnberger \& Mann, 2008; Dehez, Colson, Mann, \& Sievanan, 2008). Social carrying capacity must be measured by more than interviews to fully understand recreation use, as it is caused by many factors besides crowding (Pigram \& Jenkins, 1999; Absher \& Lee, 1981). Visitors must be interviewed or monitored to be properly studied.

There are few recreational land manager-oriented technical reports or decision-making processes that are international in scope, even with the continuing influx of visitors observed globally. There have been a number of international comparison studies conducted over the last decade (Aikoh, Arnberger, Shoji, \& Mieno, 2008; Burns, Arnberger, \& von Ruschkowsk, 2010; Li, Zinn, Chick, Absher, \& Graefe, 2006; Manning et al., 2004), but there has been little standardization of methodologies. If monitoring methods are well-documented and can be compiled, systematic comparisons can be made between specific sites, regions, and countries. This might in turn facilitate increasingly comprehensive and intuitive insight into the relationship between population trends and public recreation demand.

European countries have created a few cumulative databases, but most of that information remains in Europe. As one research group suggests "viewing parks as part of a larger regional, national, and international system [would present] a more diverse system of recreational opportunities that more fully serve the spectrum of public preferences" (Manning \& 
Lawson, 2002, p. 157). Visitor-induced impacts and resource degradation are examples of common concerns for protected area managers worldwide. Managers can use global examples to gain stronger interest from funding parties (Getzner, 2003; Knetsch \& Davis, 1966). "Research efforts should rely more heavily on multi-country approaches in order to allow for the development of models and frameworks beyond existing research and management approaches" (Burns et al., 2010, p. 32).

There have been many social carrying capacity studies throughout the U.S. since Nielsen, Shelby, and Haas first wrote about sociological carrying capacity in 1977. Some studies have particular emphases, such as: specific user type (Becker et al., 1981; Roggenbuck, Williams, \& Watson, 1993), location (Burns, Graefe, \& Absher, 2009; Manning, Valliere, Wang, Lawson, \& Newman, 2006), visitor perceptions (Leujak, 2007; Mackenzie, 1993), and estimating impact (Heberlein, Alfano, \& Ervin, 1986). Some frameworks and programs with social carrying capacity components have been applied at a national level by the U.S. Park Service (Manning, Lime, \& Hof, 1996; Pigram \& Jenkins, 1999) and U.S. Forest Service (USDA, 2004). Over 30 years of natural resource research in and outside of the United States has revealed problems with distinct similarities and distinctly different approaches to addressing these problems. This increase in visitor use will inevitably affect most public lands; therefore, strategic partnerships would be helpful across the forest system (Irland, 1979).

The European approach to social carrying capacity studies relied heavily upon visitor monitoring (Arnberger \& Mann, 2008; Hennig, 2006). Most of these studies measured social patterns to gage their impact on natural resources, rather than purely for the social phenomena. In recent years there have been a number studies undertaken of social considerations, such as social carrying capacity (Hammer \& Siegrist, 2008; Sterl, Wagner, \& Arnberger, 2004) and 
displacement of users (Arnberger \& Haider, 2007b; Freidmund, Vaske, Donnelly, \& Miller, 2002; Hennig \& Laube, 2006; Sievänen, Arnberger, Dehez, \& Jensen, 2009), especially in areas in urban atmospheres with universities nearby. Some Austrian studies have mentioned social aspects in their multi-criteria planning models or recreation use monitoring plans (Arnberger \& Grant, 2008; Synge, 2004). Gaining insight of this user-specific data and combining it with physical and biological information is a potential method of anticipating how the user base will react to management decisions, and, in turn, make decisions that impact the resources.

\section{Visitor Use Impact on the Environment}

The main ecological issue in the management of protected land is the question of how much a setting can be used without spoiling what humans find most valuable about it. This contradiction dictates the need for both social and environmental data on visitor use in order to achieve and sustain that balance between resource supply and user demand. This balance in a protected area includes many ecological criteria that must be sustained to maintain the land's unique character. Physical impacts have to do with effects on the condition of the environment and ecosystem functionality in general. Carrying capacity is the amount of use an area can take before deteriorating in appearance or quality of visitor experience (Wager, 1964), and includes as not only physical, but also biological and sociological conditions (Nielsen, Shelby, \& Haas, 1977). These three types of carrying capacity are depicted in Figure 2: Integrated Carrying Capacity Studies Diagram. 


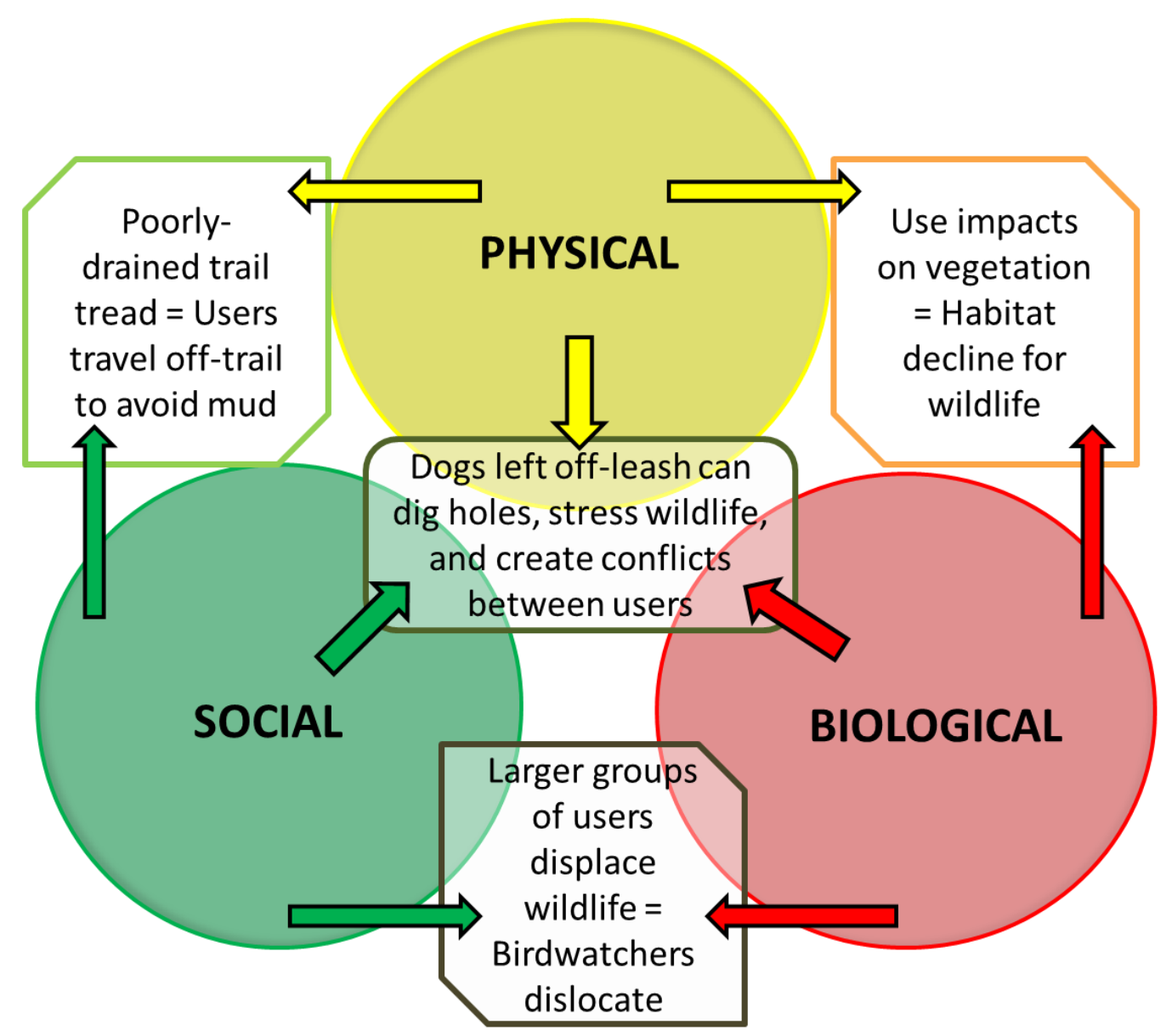

Figure 2: Integrated Carrying Capacity Studies Diagram

Human presence on natural, undeveloped outdoor recreation land is increasing, and has a significant impact on wildlife and habitat in particular. The third universally recognized type of carrying capacity is the impact visitor use might have on the fauna, or animals, in an area. The methodology used to study human impact on animals is similar across the globe. The biological carrying capacity of an area refers to how much human interference any species withstand in a certain area before they are negatively affected. This interchange refers to both direct and indirect contact with wildlife. 
Favorable recreation conditions are sometimes the conditions preferred as habitat for endangered or protected species, and "human presence can cause animals to interrupt feeding and/or mating behavior, flee or abandon preferred habitats temporarily or permanently" (Thiel, Jenni-Eiermann, Braunisch, Palme, \& Jenni, 2008, p. 845). Unaware visitors might destroy rare habitat crucial for the survival of a sensitive species without encountering a single animal. Outdoor recreation activities are "one of the main causes of the decline of all threatened species in the U.S." (Czech, 2000, p. 594). Studies on animal disturbance are popular in both the U.S. (Wasser, Bevis, King, \& Hanson, 1997) and Central Europe (Steiner \& Parz-Gollner, 2003; Storch \& Leidenberger, 2003; Wagner, Sterl, \& Arnberger, 2003) in protected areas for a variety of species.

In recent decades, increasing concerns in these concepts have led to a demand for more studies to be conducted on issues such as testing the behavioral and physiological responses of certain species to human contact (Thiel et al., 2008; Barja et al., 2007; Creel et al., 2002; Müllner, Linsenman, \& Wikelski, 2004). Such efforts seemed to work efficiently, resulting in strong biological data for habitat management. In Austria, although forestry was discontinued only a few years ago, positive changes are occurring already. Recently, evidence has been found of otter and wildcat (for the first time in decades), and black storks no longer fly away from slight disturbances in Thayatal Nationalpark (Hasler \& Paar, 2008).

Along with similar biological carrying capacity methodology, other universal practices have been used for the conservation of public lands. Most countries have numerous environmental policies or laws with which they form public land management plans. Placing land such as wilderness under special designation for protection is common (Olson \& Dinerstein, 1998). The behavior of uninformed or unsatisfied visitors can negatively impact public land 
environments. Most public land, regardless of where it is located, experiences some kind of degradation of its flora, fauna, or natural processes which is directly caused by the visitor population.

Many studies have been conducted in the U.S. on physical impacts, since they have had over a century of established protected land, and have seen heavy enough levels of use to render the method of determining physical capacities indispensable. US Forest managers follow many national conservation laws, including the Clean Air Act (EPA,1963). Since most of the laws have existed for a considerable period of time, and were created specifically for preserving US land under one agency, instructional material, frameworks, and methods to implement environmental policies are issued as part of the US Forest Service managers' policies and directives (Bean, Fitzgerald, \& O'Connell, 1991). Within the national system there are different designations of land types and uses. For example, ecological priorities have been higher when making decisions about areas within state and national forests that have been designated wilderness. There are defined riparian classifications to reflect levels of development and natural conditions along stretches of some rivers. Such classifications and designations are used to help develop management goals for these sections within the forests that embody the characteristics of these distinct management classifications (USDA, 2008b).

Many studies have been undertaken in the U.S. to determine the acceptable condition in which natural areas should remain despite human contact (Legore, 1984; Martin, McCool, \& Lucas, 1989; Roggenbuck et al., 1993). Not all recreational visitor impact studies identify negative impacts, however. A study in California by the USFS found that heavy use of a campground had hardened the area in a positive way, making the site continuously sustainable for accommodating high numbers of campers, thereby eliminating the need for implementation 
of restrictive or regulatory measures concerning campsite allocation (Magill, 1970). Carrying capacity studies have been common in the U.S. for decades (Daily \& Ehrlich, 1992; Lime \& Stankey, 1971; Nielsen et al., 1977; Shelby \& Heberlein, 1986; Wager, 1964). Even if U.S. managers are not currently running any carrying capacity studies in their area, they are familiar with the practice.

Austria is revered in Europe for its numerous biologically diverse areas, and is home to a variety of rare and highly-valued landscapes, including the longest waterfall and the last Alpine river valley in a semi-natural state in all of Central Europe. Riparian zones, floodplains, and river-marginal wetlands are highly degraded throughout Europe, and are, therefore, among the most endangered freshwater systems on earth (Hohensinner, Jungwirth, Muhar, \& Habersack, 2005; Olson \& Dinerstein, 1998).

Austrian resource managers follow many environmental conservation policies derived from a European or international level, such as: Directive on the conservation of natural habitats and of wild fauna and flora (EU, 1979), Directive on the conservation of wild birds (EU, 1992), Biosphere Reserve environmental designation (United Nations Education, Scientific, and Cultural Organization [UNESCO], 1996), report of the World Congress on National Parks and Protected Areas (IUCN, 1993), Natura2000 environmental designation (European Commission, 2000), recreational and environmental forest functions (European Communities, 2002), and Sustainable forestry (European Communities, 2003). All of Austria’s National Parks have certification with the International Union for the Conservation of Nature (IUCN, 1993). The IUCN developed a system of classifying protected areas based on management objectives with a gradation of human intervention ranging from effectively none to relatively high levels. National parks in most of the world tend to be large, natural areas, but some in Europe are "distinctive 
landscapes that have evolved over many hundreds of years as a result of traditional interactions between people and nature” (M. J. B. Green \& Paine, 1997, p. 3). Nonetheless, local communities and tourism agencies depend on the public recreation land to make a living, so visitation is strongly encouraged. There is a possibility that without the National Parks, Alpine tourism would have been reduced (Synge, 2004; Wirth, Sterl, \& Pröbstl, 2006). Austrian public land managers and researchers have contended with this seemingly paradoxical situation by constructing integrated studies that are designed to cover both the environmental conservation initiative and the aspired visitation increase.

In Austria and Central Europe many physical carrying capacity studies have been conducted more recently; a significant shift in approach considering their visitor-based research has been predominately focused on the environmental impact users have on an area (Behrens, Bednar-Friedel, \& Getzner, 2009; Glasson, Godfrey, \& Goodey, 1995; Mohl, 2004; Schiemer, Baumgartner, \& Tockner, 1999; Wipf, Rixen, Fischer, Schmid, \& Stoeckli, 2005). Most recreation studies in Austria have to do with some form of nature degradation or disturbance, such as impacts to side arm ecosystems that have been subjected to heavy use because of canoe rentals and kayak clubs (Beier, Degerman, Melcher, Rogers, \& Wirlöf, 2007; Degerman et al., 2007; J. J. Kennedy \& Koch, 2004; Müller, 1995; Sterl et al., 2004).

The studies that were not entirely eco-centric in Austria followed an integrated approach containing both ecological and social variables. This contrasts with the U.S. studies, the majority of which are separate, focusing on one or the other. In order to make informed decisions managers need to have scientifically gathered data to explain the physical and biological values they protect, as well as methodologically collected information on their users' expectations and preferences to uphold the social values they are expected to provide. These informed decisions 
have been given various names in past and current research, such as Multi-Criteria Analyses (MCD), Decision Support Systems (DSS), and sound judgments (Dennis, 1998; Hein et al., 2006; Manning \& Lawson, 2002; G. Miller, 2001; Roy, 1990; Simon, 1982; Wendt, 2006). Many other researchers in the field have described the necessity of implementing standardized analysis paradigms with the goal of achieving sustainable nature tourism (also coined sustainable recreation opportunities, Burns et al., 2010; Ferguson, 1996; Hein et al., 2006; Hennig, 2006; Lime \& Stankey, 1971; McCarthy \& Dower, 1967; Mose \& Weixlbaumer, 2006; Sievänen et al., 2009; Synge, 2004).

Emerging studies have turned from pure area protection to procedural protection, in which top-down, and bottom-up approaches are mixed (Mose \& Weixlbaumer, 2006). Recent studies in both countries have combined different methods into the same study to attain more robust results. A case study at Harz NP in Germany used the methods of counting by device and regional economic impact socioeconomic management, combined with Geographic Information Systems GIS data to determine visitor impact on resources and to compile hot-spot visitation figures with other indicators or socioeconomic issues (Burns et al., 2010). The results from these integrated studies are more reliable because of the larger amount and range of data. Especially in the social sciences, "generic assumptions and theories concerning human spatial behavior and recreational experience require validation against the real phenomena" (Taczanowska, Muhar, \& Arnberger, 2006, p. 159). In order to make informed decisions, it is crucial for public recreation managers to have a comprehensive understanding of their user bases, as well as the attributes of specific user groups within that base.

\section{Recreation Conflict}


Different types of users generally have different preferences and motivations that sometimes conflict. Common issues faced by most countries' public land managers are mainly conflicts between users due to differing preferences or overcrowded areas. These common issues are caused and exacerbated by various factors, including: type of use, size of group encountered, and behavior. Even without motorized use, Austria has had, and increasingly experiences, issues similar to those dealt with by USFS managers. Visitors can have various reactions to crowding or conflict they encounter, and respond with different behaviors, including rationalizing, shifting, displacing, and/or changing their activity (Burns, Arnberger \& von Ruschkowski, 2010; Aikoh et al., 2008; Manning, 1999a).

In order to better anticipate and combat these conflicts, management must involve visitors in their decision-making processes. Practicing transparency in management decisions, or allowing the public to remain informed and opinionated, can lead to many benefits. These include reconciliation of conflicts, compliance with designs, acceptance of management measures, and active commitment to their implication (Dennis, 1998; Hein et al., 2006; McCarthy \& Dower, 1967; Lexer et al., 2006; Mose \& Weixlbaumer, 2006).

The participatory approaches provide an appropriate framework for the identification and reduction of any land-use related conflicts. They also can be a process for related stakeholder involvement. There are three basic types of methods to maintain this transparent attribute: (a) information (social network analysis) social research; (b) consultation (in-depth interviews, questions for key user groups); (c) collaborative decision-making (interactive processes, consultations); and (d) participation in implementation of actions and analyses (regular meetings held, group could serve as long-term panel, Bachleitner \& Zins, 1999). The US Forest Service issues a communication plan along with many of its directives (Holbrook et al., 2008). In 
Europe, possibilities to participate in and affect government land use was strictly for landowners until Finish legislation in 2000, partly a result of the formation of the EU, demanded that the people involved should be heard in any land-use situation that affected their environment (Leino, 2006).

Studies have been conducted on local communities and their reactions to tourism, as well as the factors influencing how they feel (Dogan, 1989). Managers need to identify the factors influencing satisfaction within their user base, such as preferences, user group norms, and patterns in behavior. Transparency and participation are crucial in the social managing procedure (Schuh \& Oraze, 2005).

Resource managers should know and understand its visitors because every protected area experiences recreation conflict of some kind. There have been some international research studies on recreation conflict (Mann \& Absher, 2006; Saremba \& Gill, 1991; Vaske, Donnelly, \& Petruzzi, 1996). Numerous studies have been conducted to examine the interspatial, intraspatial, and temporal displacement of users in multiple countries (Becker et al., 1981; Freidmund et al., 2002; Sterl et al., 2004). Conflicts in recreation settings are extremely conditional, depending on varying measurements, including: the specific user preferences, time of day, reoccurrence, severity, weather, facility availability, and so forth. Many studies have been used to refine characteristic profiling of visitors with regard to their behavior or preferences (Arnberger \& Eder, 2007; Manning, 1999b; Sievänen et al., 2009).

Norms were traditionally used to collect social information in studies, because they are long-standing theories in social science that seem to guide human behavior in which purpose is realized and rewards and punishments are understood (Donnelly, Vaske, Whittaker, \& Shelby, 2000; Hendee, Catton, Marlow, \& Brockman, 1968; Manning \& Lawson, 2002; Williams, 
Roggenbuck \& Bange, 1991). Not all users fall under a category, however, and recreational social scientific studies have adapted accordingly. Integrated studies (see Figure 1) have become popular, as the parties involved are learning their value as assets to successfully constructing and implementing management plans (Archer, 1980; Bierwiaczonek, Geisler, \& Suchacka, 2006; Cordell, Hoover, Super, \& Manning, 1999; Heberlein et al., 1986; Knudson, 1999; Wendt, 2006). Just as ecological and social integrated studies are stronger when combined, such is the case for applying multiple methods (i.e., qualitative interviews and quantitative monitoring) within a single study.

In the US, popular subjects for recreation conflict research were displacement (Becker et al., 1981), visitors' attitudes towards management (Bourke \& Luloff, 1994), and setting-specific conflict (Karlin, Epstein, \& Aiello, 1978). USFS management has faced issues with motorized versus non-motorized users as one of their main conflicts, starting in the late 1970s, whereas all motorized use is restricted from Austrian protected areas (Nielsen et al., 1977). There is a useful connection between the three main types of recreation visitor research: preference, satisfaction, and behavior (Dogan, 1989; Louviere \& Timmermans, 1990). Preference studies show what the visitor would like to see. Some carrying capacity studies were influenced by visitor preferences (Manning, 1999b; Shelby \& Harris, 1985; Stankey, 1980; Tarrant et al., 1997). Satisfaction studies show how closely the experience meets the visitors' preferences or expectations. The connection between satisfaction and visitor behavior is displayed in Figure 3. There have been many such studies in the U.S., as satisfaction is an integral part of the management mission for most U.S. protected land (Burns \& Graefe, 2006; Cole, 2001; Holbrook et al., 2008).

There are fewer user conflicts in Austria, with the exception of several urban areas that are congested. In Austria, there are a number of conflict and preference studies, but not as many 
on actual satisfaction levels or behavior. The conflict between nature and recreation (or tourism) has been a popular topic in central Europe (Arnberger \& Haider, 2007a; Hammer \& Siegrist, 2008).

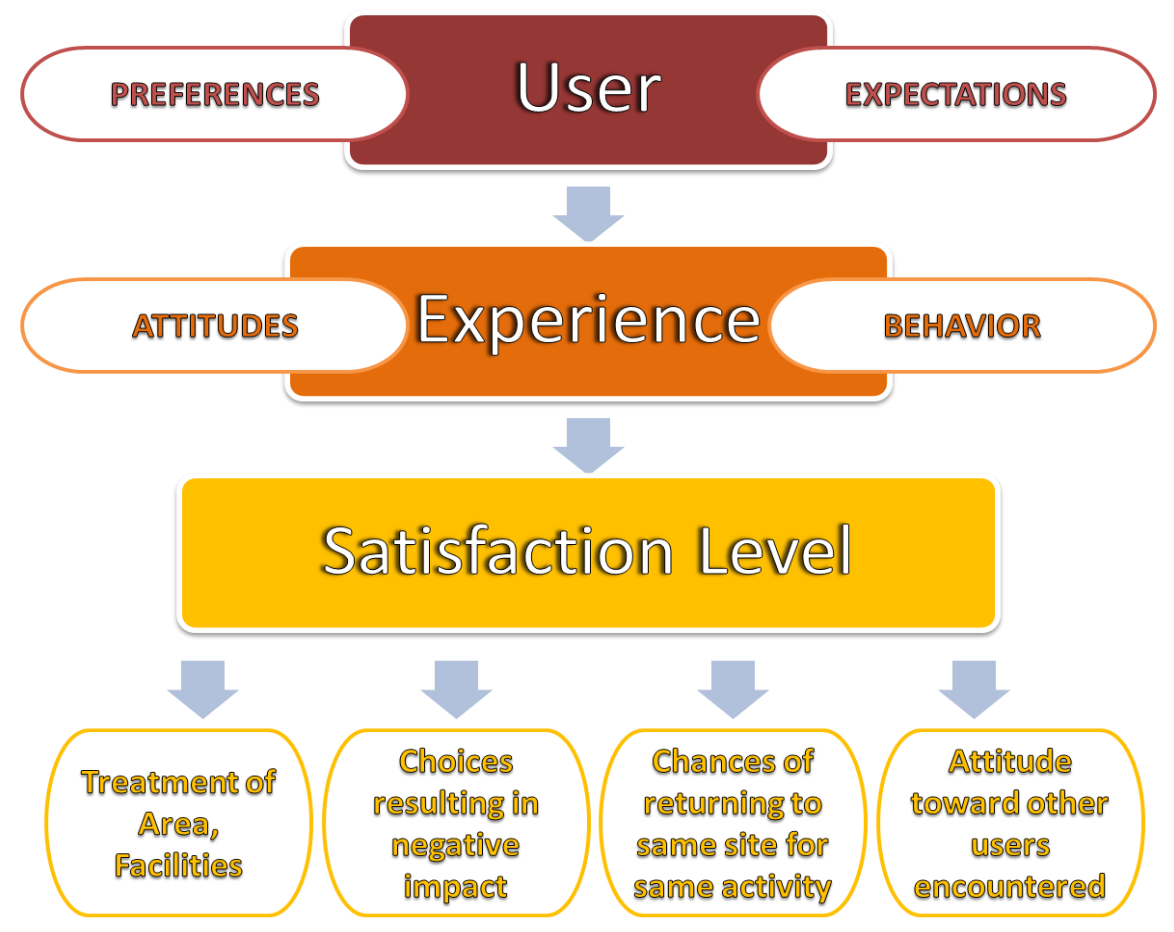

Figure 3. Satisfaction Level as an Indicator of Behavioral Response

Preference studies were also plentiful in Central Europe, especially those focusing on residents' attitudes toward tourism (Aiko, Arnberger, Shoji, \& Mieno, 2008; Bachleitner \& Zins, 1999; Muhar, Schauppenlehner, \& Brandenburg, 2006). Almost all behavior studies in Austria had to do with visitor movement and/or displacement (Freidmund et al., 2002; Sterl et al., 2004; Taczanowska et al., 2006). The others were wider-ranging visitor-monitoring studies that pointed out specific user behaviors that might have negatively impacted the area itself or other users. For example, in order to deal with an off-leash dog issue, video monitoring of urban forests in and around Vienna was executed. Then, based on common variables, the interview 
and long-term video data were combined to determine the correlation between what users said in the interviews and what they were actually doing when observed on tape (Arnberger \& Hintergerger, 2003). Managers must combine user data with biological and physical carrying capacity data in order to determine what conflicts are occurring; and of those, which conflicts are negatively impacting their areas.

\section{Techniques Regulating or Manipulating Visitor Use}

Given that use is increasing, the question arises as to whether the knowledge base of visitor patterns, impacts, and other relative information should be further studied and researched. Federal regulations are already in place for ecological purposes, but it is up to the area manager to know the specific ecological and social carrying capacity of his/her area, and to develop a customized framework from that data for managing and monitoring use (Collins \& Brown, 2007; Holdgate, 1984; Legore, 1984; Manning \& Lawson, 2002; Watson et al., 2000). Growth in the numbers of new users will call for new methodology, because of the "development of the convenience culture, the rise of the empowered customer, who wants more choice, and to changing work patterns, enabling people to spend more (and different) time freely" (Bell et al., 2007, p. 8).

By the 1950s, the US Forest Service was worried about meeting the needs of an increasing population and expanding economy; which in turn prompted the passing of the Multiple-Use-Sustain-Yield Act of 1960 (Pub. L. No. 86-5174, Stat. 215, 16 U.S.C.), to cultivate and oversee the renewable resources in the National Forests for multiple use and sustainability of their goods and amenities" (US Congress, 1960). It was the first law to address all five uses of the forests as equivalents. 
The Wilderness Act of 1964 created the legal definition of wilderness, as well as management of the nine million acres of land called the National Wilderness Preservation System (Steen, 1976). Over the years, inter- and intra-agency research collaboration led to published methods and frameworks personalized for use on U.S. public recreation land (Graefe, Kuss, \& Vaske, 1990; Manning, Lime, Hof, \& Freimund, 1995; Manning et al., 2004; Shelby \& Heberlein, 1984; Stankey, Cole, Lucas, Peterson, \& Frisell, 1985; U.S. Congress, 1960). Frameworks such as resource capacity analyses and needs assessments are not agency decisions subject to environmental analysis; but rather are analytical tools that inform an agency decision (USDA, 2008b). Along with these policies and directives came a slew of managerial resources, including access to research databases. Studies and other publications are available that delve into the physical and social constraints and triumphs of applying these policies in the field (Bean et al., 1991; Brown, 2008; Watson et al., 2000).

Austria is a decentralized country, with even its parks fully devoted to provinces (Wirth et al., 2006; Faulkner, 2004). As in many countries in Europe, Austria's policies governing natural areas and recreation are still in their initial stages. The collective or agency guidelines the Austrian areas follow outside of their provincial governments are those of a multitude of large conservation or land protection agencies. Some Austrian resource managers have chosenor are expected because of their area's classification-to adapt some of these international frameworks (European Commission, 2000; European Communities, 2002; European Communities, 2003; EU, 1979, 1992, 2000; Hockings, 1997; IUCN, 1982, 1994).

Austrian managers seem to have less immediate access to recent recreation research studies conducted outside of their own areas. Most of their information about visitor populations comes from one or several of the counting methods depicted in Table 1. Universities and 
publications on the international policy guidelines and directives are the best resources for information on policy implementation for Austrian managers (Gentin et al., 2008; M. J. B. Greene \& Paine, 1997; Harrison, Miller, \& McNeel, 1982; International Institute for Sustainable Development, 1993; McNeely \& Thorsell, 1992).

Regulatory actions. The techniques managers use to direct their visitors can range from more restrictive regulatory actions to less invasive modification methods. Regulations should be viewed as a means to an end not ends in themselves, as they are put in place to reduce conflicts among competing users, eliminate destructive behavior, increase durability of sites, and provide increased opportunities. In the U.S., where restrictions and regulations are frequently used, there are many examples of how they can be a positive method. More scrutiny of the allocation process theoretically provides a nice variety of opportunities for recreation. Performance evaluations and screening ensure the quality of outfitter/guide services. Required needs assessments ensure no crowding is caused by permitted organizations. Required carrying capacity analyses ensure habitat preservation for future generations. However, limits on the number of permits issued, or the number of campsites available, might lead to limited availability for some recreation activities (Bultena, Field, Womble, \& Albrecht, 1981; USDA, 2008a; Van Wagtendonk \& Coho, 1986). 
Table 1

Methods Available for Visitor Counting

\begin{tabular}{|c|c|c|c|}
\hline \multicolumn{2}{|c|}{ Information provided } & Method & Type of area \\
\hline $\begin{array}{l}\text { Indirect } \\
\text { methods }\end{array}$ & $\begin{array}{l}\text { Signs of use: } \\
\text { tracks/wear of } \\
\text { terrain }\end{array}$ & All kinds of land areas & $\begin{array}{l}\text { Indicator of use level / indicator of } \\
\text { spatial patterns of use }\end{array}$ \\
\hline & $\begin{array}{l}\text { Guest books at } \\
\text { cabins/trail logs/ } \\
\text { summit books/ } \\
\text { other self- } \\
\text { registration }\end{array}$ & $\begin{array}{l}\text { Large areas where use } \\
\text { is scattered, and where } \\
\text { it is difficult and } \\
\text { expensive to otherwise } \\
\text { observe units }\end{array}$ & $\begin{array}{l}\text { Indicator of use level / Indicator of } \\
\text { spatial and temporal patterns of use / } \\
\text { sometimes indicator of visitor } \\
\text { characteristics }\end{array}$ \\
\hline & $\begin{array}{l}\text { Fishing and } \\
\text { hunting licenses/ } \\
\text { statistics/other } \\
\text { documents }\end{array}$ & $\begin{array}{l}\text { Areas where permits } \\
\text { or entry fees are } \\
\text { required }\end{array}$ & $\begin{array}{l}\text { Indicator of use level / indicator of } \\
\text { temporal patterns of use / sometimes } \\
\text { information on visitor characteristics }\end{array}$ \\
\hline & $\begin{array}{l}\text { Information from } \\
\text { other agencies } \\
\text { and companies }\end{array}$ & & $\begin{array}{l}\text { Indicator of use level / indicator of } \\
\text { spatial and sometimes temporal } \\
\text { patterns of use }\end{array}$ \\
\hline & Video observation & $\begin{array}{l}\text { High-use areas with } \\
\text { multi-uses } \\
\text { Long-Term } \\
\text { observation }\end{array}$ & $\begin{array}{l}\text { Number of visits / characteristics of } \\
\text { visitors / direction of movement / } \\
\text { temporal patterns of use }\end{array}$ \\
\hline & $\begin{array}{l}\text { Observations } \\
\text { from the air } \\
\text { (direct counting, } \\
\text { aerial } \\
\text { photographs, } \\
\text { remote sensing) }\end{array}$ & $\begin{array}{l}\text { Open area where it is } \\
\text { possible to count tents } \\
\text { or boats, alpine areas } \\
\text { above tree line, } \\
\text { beaches and shorelines } \\
\text { restricted to 'snap- } \\
\text { shot' observations }\end{array}$ & $\begin{array}{l}\text { Number of visits/ } \\
\text { vehicles used by visitors }\end{array}$ \\
\hline $\begin{array}{l}\text { Automati } \\
\text { c and } \\
\text { semi- } \\
\text { automatic } \\
\text { methods }\end{array}$ & Vehicle counters & $\begin{array}{l}\text { Areas to which most } \\
\text { visitors arrive by car } \\
\text { and where the visitor } \\
\text { cars can be } \\
\text { distinguished from } \\
\text { other cars } \\
\text { (Continued) }\end{array}$ & $\begin{array}{l}\text { Number of visits / temporal patterns } \\
\text { of use / direction of movement }\end{array}$ \\
\hline
\end{tabular}




\begin{tabular}{|c|c|c|}
\hline \multirow[t]{2}{*}{ Information provided } & Method & Type of area \\
\hline & $\begin{array}{l}\text { Especially areas where } \\
\text { significant amount of } \\
\text { travel is on terrain as } \\
\text { opposed to water } \\
\text { travel, and at some } \\
\text { points most of the } \\
\text { travel is concentrated } \\
\text { on a narrow path, } \\
\text { stairs or bridge }\end{array}$ & $\begin{array}{l}\text { Number of visits / temporal patterns } \\
\text { of use / direction of movement }\end{array}$ \\
\hline $\begin{array}{l}\text { Electronic } \\
\text { counters } \\
\text { combined with } \\
\text { digital cameras or } \\
\text { video cameras }\end{array}$ & $\begin{array}{l}\text { Digital cameras: low- } \\
\text { use settings with focus } \\
\text { on information on user } \\
\text { types } \\
\text { Video cameras: } \\
\text { medium and high-use } \\
\text { settings with focus on } \\
\text { information on user } \\
\text { types }\end{array}$ & $\begin{array}{l}\text { Number of visits / characteristics of } \\
\text { visitors / direction of movement / } \\
\text { visitor behavior / temporal patterns } \\
\text { of use }\end{array}$ \\
\hline $\begin{array}{l}\text { Video } \\
\text { observation }\end{array}$ & $\begin{array}{l}\text { High-use areas with } \\
\text { multi-uses } \\
\text { Long-term observation }\end{array}$ & $\begin{array}{l}\text { Number of visits / characteristics of } \\
\text { visitors / direction of movement / } \\
\text { temporal patterns of use }\end{array}$ \\
\hline
\end{tabular}

Table 1. Methods Available for Visitor Counting. From "Monitoring of Forest Recreation Demand," by T. Sievänen, A. Arnberger, J. Dehez, \& F. S. Jensen, 2009, European Forest Recreation and Tourism: A Handbook, p. 113. Used with permission of A. Arnberger.

For management, regulations are usually beneficial if they are followed. Introducing fees collects more funding (Absher, Graefe, \& Burns, 2006; D. Brown, 2008). An organized process increases efficiency. The data collected could benefit other aspects of management. With their smaller visitation levels, most public land managers in Austria prefer subtle manipulation techniques over restrictive ones. However, the National Park Authorities in all of the European Union countries agree that the influence of European directives is continually increasing (Deutscher Sportbund, 2001). Representatives from sport organizations are expecting more 
restrictions and regulations on activities to come from the protected area designations (Pröbstl, 2003).

Modification methods. Managers can also consider modifying visitor patterns rather than restricting problematic or over-use. There are many techniques available before rationing use, such as:

- $\quad$ Sire management (behaviors, paths, rounds, irrigation, hardy vegetation)

- $\quad$ Regulating, namely behavior (zoning, rotate use, group size),

- Modifying, namely behavior (communication, fees, eligibility requirements), and

- $\quad$ Establishing priority use pools for outfitter/guides to get SUPs. (USDA, 2008b)

Whether they are employing regulatory measures or not, most areas use soft actions such as improving area infrastructure or facilities for ecological education. Educating the visitors through various forms of interpretation, exhibits, or other informational programs is a good noninvasive technique to create stewardship in users. A study in Utah showed significant changes in behavior were induced by signage (Brown \& Hunt, 1969). Onsite surveys of existing recreationists is another popular method for gathering various information in both countries (Bishop, Wherrett, \& Miller, 2001; Burns \& Graefe, 2006; Martin et al., 1989; USDA, 1996, 2004).

Overall, Austrian managers prefer these less restrictive and invasive methods, which can be referred to as visitor steering (temporal access bans, information in centers and along trails, changes in trail accessibility, Behrens et al., 2009). They believe in more invitational techniques than forbidding entry or access. For example, one manager mentioned that "visitor management starts not with the visitors' arrival, but how park and local tourism agencies promote the park to 
the public" (Synge, 2004, p. 2). Some Austrian areas established partnerships with farmers, which now provides the main income for farmers and keeps valleys beautiful for the park.

Austrian managers have often relied on collaborative management, or "ensuring that local communities and other local interests are fully engaged" (Green \& Paine, 1997, p. 5). They defined the spectrum of recreational opportunities needed, and how visitors might react to management decisions by obtaining visitor opinions. They established visitor centers, typically in villages or close to churches, and shared with other organizations so that the building was a resource for the community. Partnerships are a good way to establish the transparent management discussed in the previous section. Such agreements ensure that the people involved will be informed and can extend their knowledge about the park and wildlife protection (Prentice, Witt, \& Wydenbach, 1994; Steiner \& Parz-Gollner, 2003; Weiermar, Peters, \& Frehse, 2008).

Visitor use monitoring. Recreation research has led to the formation of methodologies that can be utilized to monitor use aspects on public land (Holdgate, 1984; O'Riordon \& Sewell, 1981). Continuous monitoring can improve services offered, ensure stakeholders are satisfied, and protect the integrity of the environment (Kajala et al., 2007; Pröbstl et al., 2009). Managers can monitor various conditions within their area that might lead to recreation conflicts, such as visitor profiling, but first they will need to identify pertinent indicator variables such as: (a) public reaction (Absher, Graefe, \& Burns, 2006; McCool \& Moisey, 1996), (b) current use (USDA, 2004), (c) future projections (USDA, 1996), (d) trouble areas (Arnberger\& Haider, 2007a), (e) visitor behavior (Freidmund et al., 2002), and (f) hot spots (Manning, 2007). Managers can monitor biological, physical, and social conditions such as inter-group encounters (Watson, Cronn, \& Christensen, 1998). These indicators are depicted in Figure 4. 
Visitor monitoring is a component of the majority of U.S. public land management frameworks. In Austria, primarily large urban areas need intensive monitoring of recreational use due to the high number of visitors, and high fragmentation of natural settings compliment short-term visitor observations (Arnberger \& Hinterberger, 2003). Most visitor monitoring studies in Austria were focused on urban areas, used video observation techniques, and were short-term-rather than cumulative-studies (Arnberger \& Brandenburg, 2002; Arnberger \& Eder, 2007; Arnberger, Haider, \& Brandenburg, 2005; Synge, 2004; Wendt, 2006). Central Europe has established long-term monitoring for ecological studies, but monitoring social dynamics is a practice still rarely in use (Burns et al., 2010; Muhar, Zemann, \& Lengauer, 1995).

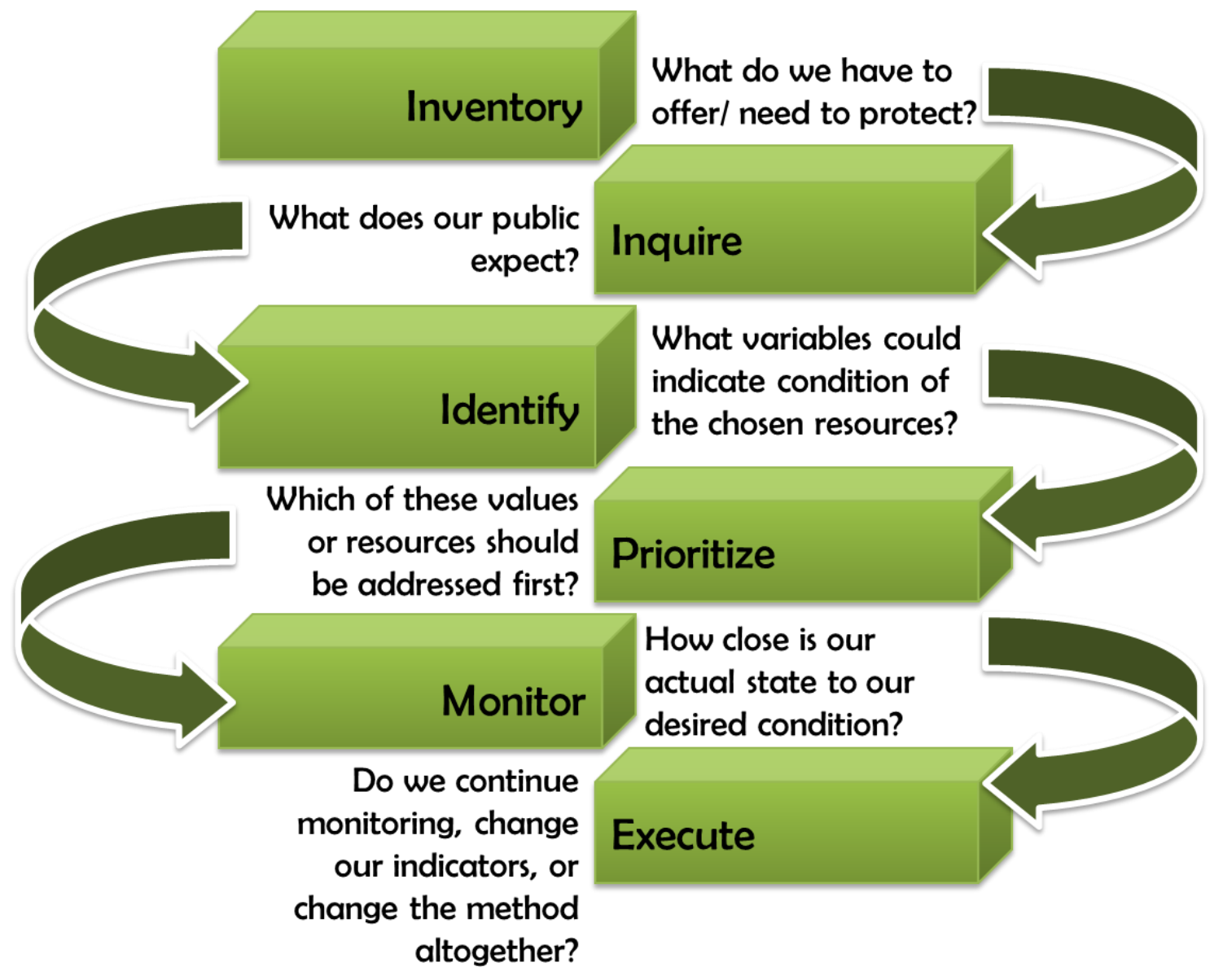

Figure 4: Identifying and Monitoring Indicator Variables. 
The models for monitoring methods designed recently, such as the visitor monitoring concept for Harz National Park in Germany, have proven to be effective (von Ruschkowshi, Valeig, Jakob, \& Homann, 2008). In one long-term study in Austria, the impacts of long-term human uses on ecological characteristics have been analyzed in several studies in recent years and will be included in the analyses of the historical development of a region of the Danube River (Hein et al., 2006). American studies have used this method as well (Aspinall, 2004; Gergel et al., 2002).

With an extensive set of variables that have been monitored over time, researchers can perform complex analyses of an area's situation. Both the U.S. and Austria have used simulation modeling (McCool, Lime, \& Anderson, 1977; Walters, Korman, Stevens, \& Gold, 2000; Wang \& Manning, 1999). Using simulations, managers can monitor developments and minimize interventions (Cole \& Daniel, 2003; Grove, 1999). Long-term inventories provide the opportunity for managers to make: stronger predictions, long-term goals, assured decisions, and better cases for funding with evidence.

Long-term inventories can also serve as part of a bigger method, such as a Decision Support System (DSS). A DSS assists multiple stakeholders in finding coherent and realistic management alternatives by linking all relevant issues in a transparent and reproducible way with the help of a multi-criteria decision aid (MCDA), evaluated according to the extended set of criteria, and then ranked with the PROMETHE outranking technique (Brans, Mareschal, \& Vincke, 1986). Another tool used for multiple criteria is the threat matrix, which can be created by listing the important attributes of outdoor recreation to form the rows of the matrix, and listing potential threats as the columns (good for monitoring resources/aspects of area that could 
be threatened, and getting a better idea of how badly each attribute is being affected (English et al., 2006; Manning, 2007).

Collaborative databases. Collective inventories also facilitate greater spanning collaborations (Sample, Price, Donnay, \& Mater, 2007; Shuttleworth, 1980; Stewart, 1989). The USFS has numerous databases of their own on various studies done in the National Forests. Regular inventories provide information for databases, along with other processes and frameworks, such as the National Visitor Use Monitoring (NVUM) system. The attempts at collecting widespread information and entering it into a database throughout Austria have been few, and only moderately successful due to lack of participation and questionable data collection methods.

Europe, as a whole, has many cooperative databases (Beier et al., 2007; Glück, 1996; Oberdorff, Pont, Hugueny, \& Porcher, 2002; Pont, Hugueny, \& Rogers, 2007). Putting information into a larger data set allows more complex analyses, ties together the researchers and managers, and focuses parties to evaluate priorities and agree on definitions (Beier et al., 2007). A database effort that turned out well was the establishment of the Council of Europe and European Environment Agency's Common Database of Designated Areas in Europe (CNPPA), which initiated collection of data on the world's protected areas in 1961 to create the World List of NPs and Equivalent Reserves. In 1981, the CNPPA established a Protected Areas Data Unit, which became part of the World Conservation Monitoring Centre, and maintains a database and GIS on the world's protected areas today. CNPPA became the World Commission on Protected Areas in 1996 (M. J. B. Green \& Paine, 1997).

There are many international agencies that exist solely to bring together protected areas in a bigger database or community for various reasons, such as internationally increasing 
transparency and comparability of areas in regard to their goals (Kaynak et al., 1994). The mission of the IUCN is to "influence, encourage, and assist societies throughout the world to conserve the integrity and diversity of nature, and to assure that any use of natural resources is equitable and ecologically sustainable" (IUCN, 1982, p. 48). The Forest Service partners internationally on a wide range of natural resource management, policy, and research issues. "Mechanisms are needed to standardize and make data available at a global level if science and the environment are to benefit from the utility of databases" (Muhar et al., 2006, p. 26).

\section{The Delphi Method}

In the literature review the origin and characteristics of the Delphi method will be described, and the legitimacy and purpose of using this method over other qualitative studies for this particular nature of research will be explained. The general goal of any application of the method is to achieve the results of a group problem-solving effort towards a complex problem without the confrontational variables of a group meeting; this can be done by consolidating the opinions of knowledgeable individuals through a research process.

The Delphi method is rather flexible in terms of its application because researchers havefound reliable variations of the method over the history of its use. However, there are five characteristics that seem to remain constant throughout the majority of studies and literature on its application (Dalkey \& Helmer, 1963; Kaynak, Bloom, \& Leibold, 1994; H. P. Kennedy, 2004; Landeta, 2005; Okoli \& Pawlowski, 2004; Taylor \& Judd, 1989). The first characteristic is that the sample consists of a panel of carefully selected experts who have considerable knowledge or experience on the topic or issue being examined. The repetitive nature of the method requires that the respondents be perseverant; continual dedication to the study is necessary to maintain high response rates. 
The reliability of a study using this method is virtually upheld by the response rate; therefore, individuals who will be directly affected by the results of the study are the most promising participants. Presumably, they will have a heightened sense of dedication if the results will be of use to them (Hasson, Keeney, \& McKenna, 2000; Kaynak \& Marandu, 2006). In this study on the values involved in recreational visitor use management on common land, the individuals involved from both countries are facilitators of the use of the land designated for the public.

The second common characteristic is that some degree of anonymity exists between the participants. The participants know the moderator (i.e., researcher) of the study and possibly some of the other panelists, but their opinions remain anonymous to one another because they are never viewed outside of the collective summary by anyone except the moderator. Emphasis is placed on the details of individuals' opinions when using this method for qualitative studies. Researchers assume that if the participants feel their statements are safeguarded from the view and critiques of others, they will express themselves fully; this allows an equal chance for all views to be considered in the collective summary.

Third, the moderator constructs a series of structured questionnaires and feedback reports for the panel over the course of the Delphi. The contents of the first questionnaire are usually derived from an extensive review of the literature. When the first round of answers is received the moderator applies the necessary qualitative analytical techniques to determine on which concepts the group's views were most closely correlated. Those concepts deemed most relevant are the basis for writing the summary and next round of questions. Use of this specific process results in the selection of topics of interest that are determined by the group as the study progresses. 
Fourth, it is an iterative process often involving multiple iterations or rounds of questionnaires and feedback reports. The multiple rounds of questions on the same subject matter give participants the option to reconsider or revise their previous views. With this opportunity, they are expected to become more "problem-solving oriented, offer their opinions more insightfully, and minimize the effects of noise" through the progression (G. Miller, 2001, p. 356).

Fifth, the flexible nature of the method lends itself to the unique character of the specific study, especially in the representation of the end product. There is no consistent method used for reporting the results. Even studies that do not achieve complete consensus or strong reliability can provide valuable information upon which to build. The "level of converged opinion [the study does achieve] still enables important lessons to be learnt from the research" (G. Miller, 2001, p. 352). Use of the Delphi method allows the design, facilitation, and presentation of the outcome of the study to be determined by its nature and purpose.

There is a vast selection of frameworks and research procedures that could be used to pursue qualitative research inquiries. The nominal group technique (NGT) and interacting group method (IGM) are two examples among the many qualitative methods commonly used in research appropriate for exploring a specific issue, identifying, and/or inventorying an existing situation. Other techniques designed to follow a rigid method and generate particular data might leave out important details, whereas the Delphi method is personalized to specific issue types and outcome objectives (Linstone \& Turoff, 1975).

Although other study methods can yield unreliable results for various reasons, the Delphi method can assess what factors could or should be attended to when structuring this technique in order to achieve their intended results (L. E. Miller, 2006). An array of group decision-making 
techniques exist, such as the nominal group technique, social judgment analysis, and the Gearing, Swart and Var techniques. All of these methods rely on expert opinion coming together to solve issues. However, these methods do not independently offer the full range of options provided by the Delphi method's flexible application and analyses that branch out from the resulting level of consensus (Gearing, Swart, \& Var, 1976; Kaynak et al., 1994).

Use of the Delphi method protects the integrity of the individuals' opinions, unlike other group techniques. Yet, it still centers on the melding of opinions towards consensus, unlike qualitative survey studies in which members of a group's individual opinions are averaged without revealing common goals. The partial-anonymity admitted through the framework that allows participants to know the moderator makes the multiple rounds featured in the Delphi method more explainable, other follow-up studies more opportune, and reminders in light of response rate more appropriate. When Van de Ven and Delbecq published their methodological study of the Delphi method and other group techniques in 1974, they attributed the rapid and widespread acceptance of the method to the solutions it provided to some of the psychological issues faced in group methods in which the panel was physically gathered. The method has other strong advantages, including the minimal travel costs and coordination efforts required because the Delphi method does not require a central location if conducted via email (Kaynak \& Marandu, 2006; Loo, 2002).

The Delphi method resulted from a series of studies in the 1950s conducted for military purposes by the RAND Corporation to find the best technique to solicit the opinion of a group of experts, and later proposed its use for the planning of developing economies (Dalkey \& Helmer, 1963; Helmer, 1967). In the 1960s, the U.S. armed forces released the method to the public, expanding its use into the fields of technological forecasting. During the first decade of its 
existence the method was strictly used for long-and short-term forecasting studies with the objective of consensus of opinion. Subsequently, researchers used the method to produce a set of alternate future scenarios by emphasizing the opinions that fell outside of the general consensus (Gupta \& Clarke, 1996; Okoli \& Pawlowski, 2004). Enabling the identification of consensus on multiple points led to studies designed to identify multiple concepts and then rank them by collected priority. The Delphi method has been applied in numerous fields ranging from the field of medicine (Hasson et al., 2000; H. P. Kennedy, 2004; Mullen, 2003), to policy and program development for police organizations (Loo, 2002), and information science research (Landeta, 2005; Okoli \& Pawlowski, 2004). The adaptable qualities of the method make it potentially useful in any field, and practically indispensable in others.

The Delphi process proved to be a useful and effective method within the recreation field to determine factors that will ultimately alter the future of the industry. Dyck \& Emery (1970) used the technique to predict the future distribution of work and leisure time from six panels of experts in their Canadian study, and were even able to output forecasts, dates, and trends. Studies from all over the world use the Delphi method as a forecasting tool to predict future tourism potential (H. Green, Hunter, \& Moore, 1990; Kaynak et al., 1994; Kaynak \& Marandu, 2006; Kibedi, 1981; Yong et al., 1988). In a study conducted in the United Kingdom experts were asked to develop indicators that might aid consumers in the selection of their holidays, and by doing so, indirectly promote a more sustainable form of tourism. They asked their respondents to: (a) identify what they believed constituted sustainable tourism, (b) determine what criteria are necessary for designating successful indicators, and (c) which indicators promote a more sustainable form of tourism (G. Miller, 2001). 
In Spain, Landeta, Matey, and Ruiz (2002) applied the Delphi method to determine what factors were needed to build an effective model for estimation by asking tourism providers in the area what they thought would be necessary. Some qualitative Delphi studies have been made into stronger, integrated studies, combined with quantitative data to measure the desired phenomena, and vice versa. Archer (1980) employed the qualitative Delphi method to identify both the quantitative and qualitative factors that would later be measured as influences on the choice of policy in predicting future tourism developments. There are many working, reliable, and current examples of the Delphi technique being applied to recreation-related research, and this sizable history further supported its use in this qualitative study.

\section{Conclusion}

Values are practical for use in social scientific research, especially in the field of recreation visitor management in which they serve as great standards of conduct and are remarkably stable over time. It is becoming increasingly important to conduct research on each area's specific user base, as values themselves are becoming a respected component of social scientific research. As Manning and Lawson (2002) wrote in their article on this subject, "the science of values is progressing to meet the opportunities and challenges of the values of science to recreation management" (p. 159). Visitors seem to have some negative impacts on their natural surroundings, as well as each other. Social carrying capacity is used to evaluate what is disturbing the user base's satisfaction levels, or preferences, enough to cause them to display negative behavior, such as displacement.

There are numerous studies from both the U.S. and Austria that assessed the physical impact of visitor use on nature, but the studies on social impact in Austria are usually a part of a larger integrated study. Both the U.S. and Austrian managers follow policies and/or directives 
on conservation, and sometimes visitor management. They both employ similar actions to meet their policy guidelines, but Austrian managers do not have the plethora of frameworks available, and prefer modification methods over more restrictive ones. Technology seems to be similar in the two countries, as are observation and monitoring techniques. Some international and collective approaches have been undertaken already, but the future of recreation-related research would benefit from more studies with a better emphasis on integrated or combined approach of both research fields simultaneously (Burns et al., 2010). This idea is the reason why managers not only follow strong value-driven policy, but also familiarize themselves with their user base, this will help them achieve the most accurate results from their analyses. Accurate results enable managers to formulate the most personalized techniques in order to determine the most sustainable courses of action. 


\section{Chapter 3: Methodology}

This study included two open-ended pilot interviews and two rounds of qualitative questionnaires constructed and administered using the Delphi method. The design of the Delphi methodology calls for the direction and scope of the research topics throughout the study to be dictated by the participants' collective answers.

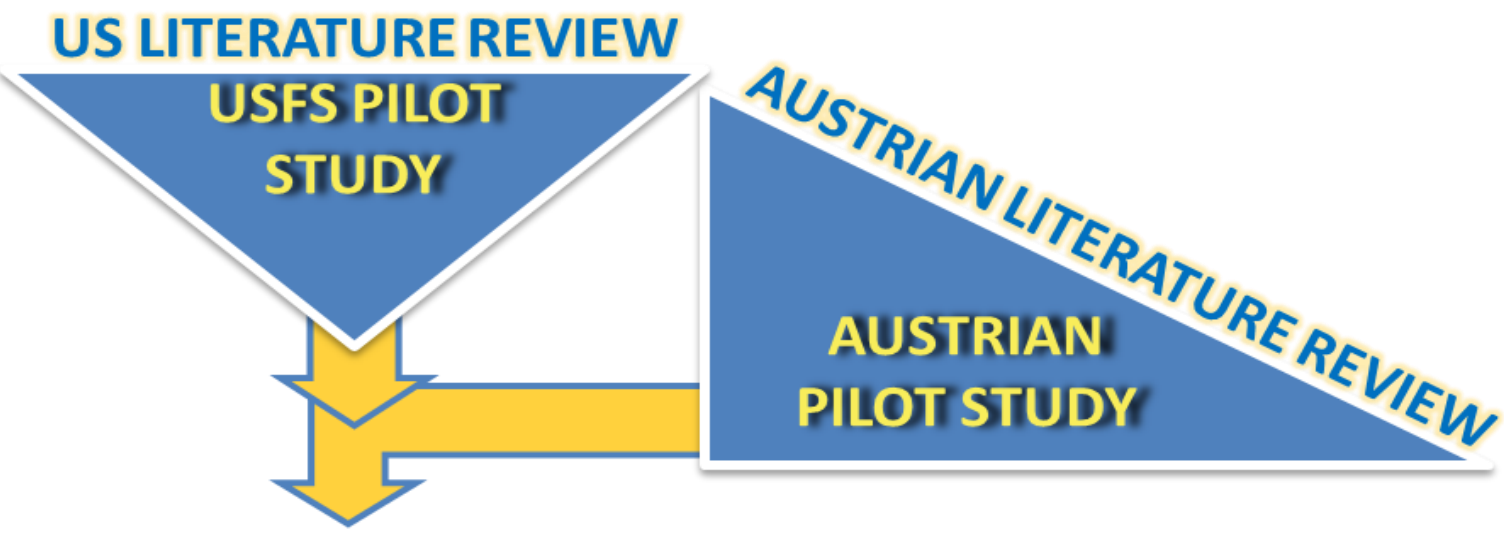

\section{GUIDED, THEMATIC LITERATURE REVIEW}

\section{DELPHI: ROUND 1}

\section{FOCUSED, KEY CONCEPTS LITERATURE REVIEW}
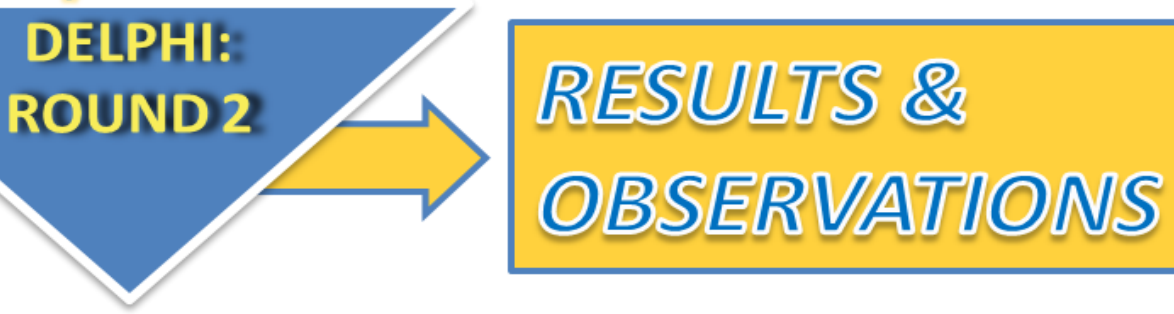

Figure 5. Research Process Literature Review Model. 
Several Delphi studies suggested the researchers developed a knowledge base from available publications prior to operating the study, in an effort to familiarize themselves with the relevant themes (Dalkey \& Helmer, 1963; Hasson et al., 2000; Mullen, 2003). The pilot studies and following literature review were executed in anticipation of the common answers the panel of experts would identify, as demonstrated in Figure 5.

It is the responsibility of the researcher to be able to understand the industry and concepts well enough to make sense of the range of answers they receive in order to summarize and facilitate the consecutive rounds. The broader research questions were formed with the intention of conjuring key words and concepts pertaining to the desired research themes that could be formed into the various rounds of questions on the research instruments to come. The research themes in this study were social carrying capacity, management frameworks, policy \& techniques, and recreational research collaboration. Therefore, the research questions listed below were reviewed in preparation of the formation of questionnaires and the treatment of the pending manager responses.

\section{Research Questions}

RQ1. What are your (manager) main goals concerning visitor use management?

RQ2. Do you (manager) perceive that your users are experiencing crowding/conflict?

RQ3. What (if any) social carrying capacity methods are in place at this area?

RQ4. Does recreational use appear to have any negative impacts on the natural resources of your area?

RQ5. Is a forest/site/area management plan in effect?

RQ6. What (if any) use restrictions are in effect? 
RQ6a. What other non-restrictive techniques are used to manipulate visitor flow and/or behavior?

RQ7. What (if any) visitor monitoring procedures are in effect at this area?

RQ8. What are your thoughts on standardizing visitor use methods for communicating and/or collaborating on research efforts?

RQ9. What are some possible constraints or limitations that must be addressed when collaborating internationally?

RQ9a. Why would international collaboration be beneficial and ultimately necessary in the future?

RQ10. What are the possible benefits and limitations of using the Delphi methodology for recreation-related research?

Table 2

Participating Areas

\begin{tabular}{|c|c|}
\hline U.S. National Forests & Austrian Protected Areas \\
\hline Columbia River Gorge National Scenic Area & Biosphere Reserve Wienerwald (Vienna) \\
\hline Deschutes - Ochoco National Forests & Dürrnstein Wildnisgebiet \\
\hline $\begin{array}{c}\text { Grand Mesa, Uncompahgre \& Gunnison } \\
\text { National Forests }\end{array}$ & Lechtal Naturpark - Natura2000 \\
\hline Monongahela National Forest & $\begin{array}{l}\text { Nationalpark Donau-auen [Danube Floodplains } \\
\text { National Park] }\end{array}$ \\
\hline Mount Baker - Snoqualmie National Forest & Nationalpark Gesäuse (Styria) \\
\hline Mount Hood National Forest & Nationalpark Hohe Tauern \\
\hline Olympic National Forest & Nationalpark Neusiedler See-Seewinkel \\
\hline Rogue River - Siskiyou National Forests & Nationalpark Thayatal \\
\hline
\end{tabular}




\begin{tabular}{|l|l|}
\hline & \\
\hline Siuslaw National Forest & \\
\hline Umatilla National Forest & \\
\hline Umpqua National Forest & \\
\hline Wallowa - Whitman National Forest & \\
\hline Willamette National Forest & \\
\hline
\end{tabular}

\section{Collection and Treatment of Data}

The empirical and vast nature of the qualitative data gathered in this study required the extensive use and documentation of recognizable qualitative analysis techniques to strengthen the findings. Word-based techniques are fast, efficient ways to start looking for category themes, especially in the early stages of an identification process (Ryan, 1999). The pawing technique, also called the ocular scan method, or simply eye-balling, was used to get a feel for data by handling it multiple times, highlighting key phrases, and waiting for patterns to emerge (Ryan \& Bernard, 2000). The more personal methods of interviewing over the phone and on-site interviewing for the pilot studies gave the researcher in this study more confidence with their intuition when it came to identifying these key themes.

These more personal forms of communication promoted a more comprehensive understanding of the respondent's intended context for each of their statements, as they were personally delivered and could also be questioned if not fully understood. The technique of finding key-words-in-context (KWIC) was also applied to this study. Noting how recurring words were used, the context in which they were said, and writing the full phrase in which they were used allowed the answers in this study to be analyzed across the two different countries and many different systems in this study. There is no substitute for following intuition when 
identifying themes to code texts (Bogdan \& Bilken, 1992; Dey, 1993). The literature was consulted to assist in the search for category themes that were not already apparent and specific.

The method of social scientific query was crucial to keep things in perspective in this study. Considering the major social and cultural themes in this study, prior research was needed to identify the KWIC correctly, so a literature review on each country's culture and history in relation to recreation management policies was necessary in order to not only first gauge if the comparison was possible, but also to provide understanding of the indigenous categories mentioned. Indigenous categories refers to terms or concepts that might sound unfamiliar, but if the context of how the group of people in question use that term is understood or researched, it can be better understood and properly placed in the corresponding theme or category (Ryan \& Bernard, 2000). The researcher's attention to detail for these qualitative methods, as used within the Delphi process, ensures the maximum extraction of valuable information for any qualitative query.

U.S. pilot study. The 20 contacts for the U.S. pilot study were provided by the U.S. Forest Service Pacific Northwest Regional management as part of a research partnership with West Virginia University to survey the district managers about their understandings and feelings with regard to the newly implicated Federal Register changes to recreational outfitter and guide policies. The interviews consisted of the 12 open-ended questions listed below, and were conducted over the telephone during October through December of 2008. The response rate was $100 \%$, which was expected, since the USFS Pacific Northwest region commissioned WVU to design and execute the study. The full instrument can be found in Appendix A.

The research instrument was designed to get a general idea of who handles the distribution of recreation Special Use Permits (SUP) for each particular forest, and what 
activities or events are he or she manages. The number of SUPs distributed each year was revealed, and a determination made about whether or not it had changed from previous years, in order to get an idea of views on the fluctuating number of users. Questions were asked about partnerships, processes, and constraints within the SUP distribution process to find commonalities across the region. The managers were asked about limitations and restrictions on users under their current allocation process. Finally, they were asked for their opinions on their current distribution process, and their feelings about the Federal Register changes.

The recorded responses were examined, looking for word repetitions, or words mentioned by a good portion of managers in the study. These key words were then reassessed in the context (KWIC) in which they were used, and compared and contrasted with the other participants' answers in order to gain a better understanding of these recurring concepts. The answers were then analyzed a final time, keeping in mind the indigenous categories (cultural or social terms or conditions that may affect language and understanding) and social scientific queries (background information researched on the concepts themselves in the context in which they apply to their specific informants) found from the preliminary literature review that directly applied to the newly emerged key concepts. The recurring key concepts or themes that were identified through this process were summarized for each question, as the same answers were recurrent for nearly all managers for each question, and the smaller number of participants could render percentiles misleading. Therefore, the informal technique of word repetition was applied to this pilot study's results: the consensus on the few concepts that were mentioned for each question could be easily noted without having to be inventoried or listed and counted.

Austrian pilot study. The 11 contacts for the Austrian pilot interviews were either suggested or provided by key informants in Austrian park and university settings. The translation 
of all of the introductory requests sent by phone and email, reminders sent by email, and research questions were handled by the author. The open-ended interviews were conducted on site at each of the managers' resource areas. The response rate was $100 \%$; with all selected managers participating in the interviews. It should be noted that although there are 11 Austrian participants, three of them are co-administrators so the study covered eight areas. The full instrument is in Appendix B.

This questionnaire was written to incorporate the Austrian managers into the study to ultimately compare methods and policies within the two countries. The Austrian managers were asked general, encompassing questions, such as their job title, daily responsibilities and long term responsibilities/goals in order to establish a common ground. Then, more specifically, they were asked if there is enough recreational use in the area to cause concern of degrading natural resources, and how they manage these. They were then asked if there is enough use to cause conflict between users, to touch on any social carrying capacity methods they might use. Finally, they were asked to give their best definition of visitor management, mainly to see how the ideas contrasted or melded across the country; and in juxtaposition to those of the U.S. managers.

The recorded responses were examined, looking for word repetitions and KWIC, and comparing and contrasting key concepts, while keeping in mind the indigenous categories and social scientific queries found during the preliminary literature review that directly applied. The recurring themes identified through this process were those mentioned as significant by the majority of managers. The formal technique of word repetition was applied to this pilot study's results; because of the larger range of answers found that were mentioned by more than two participants, they had to be not only noted as in the first study, but also listed and counted. These answers were then compared and contrasted with those of the U.S. pilot study to find the 
common themes and specific concepts and issues that could be studied on the common level identified by the literature review. The level upon which comparisons could be made was the topic of values. The first Delphi instrument was constructed based upon these findings, and reviewed by accommodating affiliates well-versed in recreation management studies.

Delphi survey-First round. The respondents from each country were administered the same instrument for the Delphi studies, as opposed to their own, as in the previous pilot studies. The translation into German for the Austrian managers in the study was done by German speaking faculty, who have extensive knowledge of nature and visitor management on public land. The respondents participating in the pilot studies were all administered the questionnaire by email in October of 2009, with a two-week period encouraged for completion, along with reminders prior to and after its delivery. Of the 13 U.S. managers, nine responded with completion of the survey instrument; along with eight of the 11 Austrian managers. The First Round Survey is found in Appendix C.

The flexible but common ground on which to conduct the comparison was determined to be values, as touched upon in the literature review. The first round of Delphi questions sought to gain a general profile for each park, including: resources, main recreational attributes, estimated economic value, unique features, amount of use, and management/regulation policies. Managers were then asked a few questions about the methods and techniques they use for visitor management, including any frameworks. They were asked about user conflicts, and finally, their level of knowledge on recreational visitor management research.

The answers were examined, looking for word repetitions and these KWIC, comparing and contrasting key concepts, keeping in mind indigenous categories and social scientific queries until general themes were identified, listed, and eventually coded. The coding framework was 
then used to list and inventory (count) the recurring concepts and issues within these apparent themes that were mentioned as significant to the majority of managers. These uniformly significant concepts were then used along with techniques of searching for missing information such as a follow-up literature review on these concepts, and a review by a participating manager to ensure maximum comprehension from the respondents prior to the administration of the second survey. The results are delivered in an informal manner because the small number of participants in the sample does not yield significant quantitative measures, only percentages. Only researched observations and informed judgments can be made by the researchers.

Delphi survey-Second round. The second instrument, found in Appendix D, was constructed and administered to the responding participants from the first round of the Delphi questions which were distributed in early August, 2010. A two-week span was encouraged for completion, along with the same prior and post-delivery reminders. A condensed summary of the results of the first round was sent along with the second instrument. The German translation was provided by a research assistant in Austria who is highly experienced in the field of recreational research, especially that of social carrying capacity.

Even with the same frequency of reminders, the response rate was considerably lower, with only six out of the nine USFS managers responding, and $j$ twost of the eight Austrian managers responding to and completing the second survey. The two managers responding from Austria work for the same protected area; therefore, the entirety of the group's answers were analyzed as one, since no supported comparisons could be made between the two countries in this round with only one area in Austria represented.

The same three themes used to organize the round one questions and results (visitor use impacts on natural resources, user versus user conflicts, and management practices/methods) 
were presented to the participants in the summary that was sent with the second-round instrument (see Appendices A \& B). While round one questions focused on the current visitor situations and issues, round two centered in on the methods used to achieve ideal conditions, along with other topics found to be widely relevant after analyzing the answers from the first round. When necessary, for purposes of normalization, existing published categories formed from studies conducted on issues of recreation visitor management and social carrying capacity concerns were adapted (Manning, 1999b) and applied to the categorization of this study.

In this instrument, the respondents were given both a series of questions in the form of a list of statements, in which they were asked whether they experienced or agreed upon (known as stated choice method when used quantitatively), and also a series of questions in which they were asked to prioritize or rank lists of concepts or entities that were identified as common concepts or issues in the study. These techniques, in their qualitative context, were designed to further streamline the answers, and start to identify the similarities and differences in what is most important among the common values and goals in the managers' situations. Theoretically, these techniques should have led to a greater ability to observe possible patterns or relationships between: policies/certification guidelines upheld, management actions/ techniques/frameworks/systems executed, and prioritization of these common values or objectives. The poor response rate degraded any kind of analysis for this last round of data down to strictly observational insights into the concepts in question, rather than the more reliable qualitative results from the following rounds.

This instrument had some stated choice questions to further investigate common concepts, such as opinions on the amount of impact visitor use has on natural resources, and managers' levels of enthusiasm towards research collaboration with other managements. These 
questions also went into detail on common variables causing common phenomena. They were asked to rank these variables, such as invasive species, as a negative impact from visitor use. They were also asked for more details about the nature and intensity of their conflicts. They were also asked to go into detail with open-ended questions about their management techniques and frameworks, and the considerations driving them.

The open-ended answers were pawed through, looking for word repetitions and KWIC, comparing and contrasting key concepts, keeping in mind indigenous categories and social scientific queries until general themes were identified, listed, and eventually coded. The coding framework was then used to list and inventory the common concepts within these apparent themes that were mentioned as significant by the majority of managers. These uniformly significant concepts were then used along with techniques of searching for missing information, such as a final literature review on these concepts, but they obviously could not be compared for international trends, since the data was overwhelmingly one-sided and statistically incomparable due to the low response rates on both sides. Overwhelmingly, the fact that there were only two respondents from the same area in Austria made their information interesting in terms of the general concepts of the study, but unusable as the representation of the collected Austrian managers' responses for a comparison against those of the six U.S. managers.

\section{Limitations}

Overall, the empirical nature of the study, multiplied by the requirements of the Delphi methodology from the participants (open-ended questions, continued participation between longer spans of time) wore down the participation level of an already small sample size, rendering the results of this study to be interesting and suggestive, but not conclusive or significant. 
The Delphi method does have its limitations. Researchers using the technique must realize that: (a) responses from different panels to the same question can differ substantially, (b) the consensus achieved in later rounds might be due more to some pressure to conform than to a genuine converging consensus of opinions, and (c) the use of open-ended questions can make it difficult to assess measurement reliability and validity. Other limitations of the study that should be noted are: some of the interviews and/or pilots came at an extremely busy time for some managers, and the Austrian side of the literature review could have been stronger-studies that were not available in English could only be used in reference, and not read beyond the abstract by the researcher. Prior inquiry into the seasonal workload of the participants could have been made to try and contact them at the best time.

A full literature review for a comparison between two countries should have a full representation of literature from both countries. Thanks to ongoing research cooperation with a university in Vienna, Austria, the literature review was well represented from both countries in this study, and a background understanding was personally provided. Just as this study recommends collaborative research efforts, the best reviews of multi-country literature would be done as a collaborative effort between researchers from both countries. The shortcomings of this study reviewed here were previously noted in greater detail in various sections throughout the paper.

The disadvantages to using the Delphi method are multiple, but mostly manageable. While response rates are generally critical in all studies, the lower-than-average minimum panel size of the Delphi method causes results to be extremely sensitive to the continued response of the few participants. Time is always of concern, and the amount of work between rounds can consume vast amounts of time if not planned in advance or staffed sufficiently. 
Coupled with the commitment expected from participants to address the same concepts multiple times, the dropout rate might tend to be as high as $50 \%$ with some groups (Kaynak et al., 1994; G. Miller, 2001). The open-ended quality of the process leaves room for bias or leading of the participants by the researchers (Dalkey \& Helmer, 1963). This inclination was anticipated in this study, and caution was exercised while forming research questions to ensure that the questions did not unconsciously guide or persuade. According to Taylor and Judd (1989), and later Miller (2001), the most significant potential weakness is not asking relevant or efficient questions. As mentioned above, the initial steps of the process are to anticipate indicators and then inquire as to whether-and how-important they are. Without strong, meticulous questions pointedly directed at what the researcher is seeking, the study will be unfocused and unavoidably generalized. This vagueness was avoided by a number of efforts, including thorough preparatory literature reviews and pilot studies.

The literature reviews, pilot studies, and Delphi questionnaires proved their efficiency in this study, yielding a fair amount of useful results and observations. The Delphi method was used with the intent of obtaining a realistic bias for comparison that would be relevant for all parties involved. This was the best way available to get individually biased answers to the posed research questions in a collaborative way. 


\section{Chapter 4: Results}

Even though the initially anticipated juxtaposition of visitor management frameworks was not possible, deciphering the common value categories as a means of comparison proved to be very efficient for the empirical, qualitative nature of this study. From the lengthy, detailed pilot interviews the three common categories of values upon which the recreation managers based their actions and decisions were revealed: natural, social, and managerial. These value categories were expanded for the first Delphi survey into detailed, particular answers from which the similarities could be picked out and condensed into a more focused second instrument that would still be relevant to all participating managers.

RQ1. What are your (manager) main goals concerning visitor use management?

The answers concerning manager goals spanned the range of natural, social, and managerial considerations. Many of the managers mentioned managerial issues, such as "achieving policy guidelines." Several of the managers had social aspects in their answers, such as "maintaining visitor satisfaction" or "creating exceptional visitor experiences." Most, if not all, had some kind of nature conservation goals listed.

RQ2. Do you (manager) perceive that your users are experiencing crowding/conflict?

Most managers reported having issues with crowding only on holidays or weekends, or in particular concentrated areas (hot-spots). Even in the areas that did not perceive crowding, they still faced user conflicts such as bikers vs. hikers, or groups vs. individuals. Conflicts in recreation settings were extremely conditional, depending on varying measurements, including: the specific user preferences, time of day, recurrence, severity, weather, facility availability, and a slew of other common circumstances. A handful of the USFS managers listed the NVUM process as a social carrying capacity evaluation method, but that was the only social carrying 
capacity technique mentioned. Regular visitor activities reported are demonstrated in Table 3 and common conflicts in Table 4 .

Table 3

Regular Visitor Activities

\begin{tabular}{|l|l|}
\hline \multicolumn{1}{|c|}{ US } & \\
\hline Hiking/walking & Hiking/walking \\
\hline View natural scenery & Cycling \\
\hline Camping, Fishing & Fishing \\
\hline Off-highway vehicles & Nordic skiing \\
\hline Snow-board/skiing & Family fun (picnicking, etc.) \\
\hline Family fun (picnicking, etc.) & View natural features \\
\hline Cycling & Camping \\
\hline Scenic Byways & Off-highway vehicles \\
\hline
\end{tabular}

Table 4

Recreation Conflict

\begin{tabular}{|l|l|}
\hline \multicolumn{1}{|c|}{ US } & \multicolumn{1}{|c|}{ Austria } \\
\hline Most visitors experience conflict & Few visitors experience conflict \\
\hline River/riverbank & River/riverbank \\
\hline Access roads/highways & \\
\hline Peak use times & \\
\hline
\end{tabular}

RQ3. What (if any) social carrying capacity methods are in place at this area? 
In order to determine SCC the values and expectations of the various user groups in the area must be determined. Several methods and numerous site studies were undertaken in the U.S. exploring this social concept and its most effective indicator variables. Most Austrian managers experience some peak usage issues, or crowding. Busy times during holidays or weekends and conflicts between user groups occur, but not at a high enough frequency to justify any extensive social research on their visitors. However, public land managers encounter many social values within their areas' plans that are seemingly identical to the values driving such research studies in the U.S. For example, Austrian programs involving local schools brought 80,000 students into the National Parks in 2007, and the same year saw 32,000 people attending guided hikes or similar programs (Hasler \& Paar, 2008). The results on visitation from our study are shown in Table 5. Outside of the provided infrastructural facilities the social data is generally estimated or unknown, and it is in these circumstances that knowledge of existing visitor monitoring methods would be helpful.

Table 5

Understanding Visitor Use

\begin{tabular}{|l|l|}
\hline \multicolumn{1}{|c|}{ US } & \multicolumn{1}{|c|}{ Austria } \\
\hline $13,000-4$ million per year & Unknown (less than 1 million) \\
\hline Slight increase in visitation & Slight increase in visitation \\
\hline Population/economy trends & Estimate/observation \\
\hline
\end{tabular}

RQ4. Does recreational use appear to have any negative impacts on the natural resources of your area?

Managers from all but one area in the U.S. and one in Austria reported experiencing some kind of degradation or negative effect from at least one type of visitor activity. Motorized 
use was the most damaging in the U.S., but is banned in Austria. In both countries, even in areas that did not see a significant amount of use, the behavior of going off-trail was listed as a recurring damaging activity. Perceived visitor use impacts are reported in Table 6 and activities perceived to be causing these impacts are in Table 7. Crowding or hot-spots were also listed by many as problem-causing phenomena. A large difference between public recreation management in the two countries is that while the U.S. relies heavily upon private ownership and management of many forest services provided, Austria has virtually no commercial use of any National Park land. The USFS allows commercial use of lands to enhance recreational operations and to promote appropriate resource use. Most consumptive activities are also prohibited in Austria (timber, mining) or are on the decline (forest product gathering, hunting, fishing).

Table 6 Perceived Visitor Impacts

\begin{tabular}{|l|l|}
\hline \multicolumn{1}{|c|}{ US } & \multicolumn{1}{c|}{ Austria } \\
\hline 6Vegetation loss & Wildlife disturbance \\
\hline Riparian loss & Birding habitat disturbance \\
\hline Soil compaction/erosion & Vegetation loss \\
\hline Water quality degraded & Soil compaction/erosion \\
\hline
\end{tabular}


Table 7

Perceived Activities Causing Impacts

\begin{tabular}{|l|l|}
\hline \multicolumn{1}{|c|}{ US } & \multicolumn{1}{|c|}{ Austria } \\
\hline Hiking & Hiking \\
\hline Boating & Fishing \\
\hline Off-highway vehicles & Agriculture use \\
\hline Camping & Boating \\
\hline
\end{tabular}

RQ5. Is a forest/site/area management plan in effect?

All areas had a management plan in effect, but many of the Austrian areas were applying their own policies, which they had translated from their broader conservation agency guidelines to fit their individual areas. Most of the USFS managers listed the frameworks they applied, such as the Level of Acceptable Change LAC, or listed the Directives. Concerning specific visitor management techniques, the U.S. managers again listed frameworks such as NVUM, or LAC, and others explained that there were certain designated areas that were monitored. Frameworks and management plan results from this study are shown in Table 8. The field application or on-site references in this study are on a ranger-district or forest level within the Pacific Northwest region (PNW) of the United States. The region contains some urban-oriented forests (near Portland and Seattle) and a large number of rural forests. Each administrative unit is comprised of several ranger districts operating under a Forest Supervisor, who answers to the Regional Forester, who, in turn, reports directly to the Chief Forester. Policies issued by the agency on everything from recreation facilities to research is in the form of a Forest Service Directive. The USFS has classifications of sites or systems within the agency that come with 
uniform attributes and policies which must be maintained, such as: U.S. National Trail System (NTS), National Scenic Byways (NSB), Wild \& Scenic Rivers (WSR), and Operating soundly and efficiently within FS directives (FS Performance and Accountability Reports).

Table 8

Visitor Management Frameworks

\begin{tabular}{|l|l|}
\hline \multicolumn{1}{|c|}{ US } & \multicolumn{1}{c|}{ Austria } \\
\hline Discourage inappropriate use & Educate visitors \\
\hline Limit group size & Discourage inappropriate use \\
\hline Fines/penalties/warnings & Fines/penalties/warnings \\
\hline Implement a framework & Limit group size \\
\hline Educate visitors & Implement a framework \\
\hline
\end{tabular}

A similar initiative in Europe is Natura2000, in which directives are integrated into an efficient management plan, making a good tool to manage requirements of sensitive species, habitats, and use (Wirth et al., 2006). These directives need to be integrated into the management plan along with National laws, regulations, and administrative provisions on top of maintaining policies and guidelines. A good example of how many organizations and agencies get involved with the Austrian projects is the LIFE River Restoration initiative, which is a research collaboration involving: Water Management Authority of Carinthia, Federal Ministry of Agriculture, Forestry, Environmental \& Water Management, Nature Conservation Authority of Carinthia, World Wildlife Fund Austria, EEA (European Environment Agency), UNEP (United Nations Environment Program), UNDP (United Nations Institute for Sustainable Development), UNCSD (United Nations Commission for Sustainable Development), IISD (International Institute for Sustainable Development), WTO (World Tourism Organization), EU Birds 
Directive, Austrian Red List, and the EU Natura2000 site, as well as government organizations such as the Austrian Ministry of Science, Federal Ministry of Transport, Innovation \& Technology, and Municipal Authorities of Vienna, and the Provincial Government of Lower Austria (2004). Even though there were complaints from the U.S. managers about limited funding, in Austria, no national agency for recreation means no guaranteed annual funding. Some Austrian managers have the burden of procuring their area's budget every year from multiple sources.

RQ6. What (if any) use restrictions are in effect?

The Austrians initially listed no restrictions on recreation activities, but some areas or activities are restricted or forbidden within the protected areas (such as motorized vehicle use or fishing). The only other limiting measure mentioned was a limit on the number of hikers allowed into a particular wildflower sanctuary at its high-peak use period. The U.S. managers listed an array of answers, many of them relating to specific handbook guidelines or wilderness area specifications. Other popular answers were the regulation of campgrounds, licensing or permitting, limiting group size, limiting the number of people in a particular area, and closing sensitive sites. The results on restrictions are demonstrated in Table 9.

Table 9

Visitor Use Regulation

\begin{tabular}{|l|l|}
\hline \multicolumn{1}{|c|}{ US } & \multicolumn{1}{c|}{ Austria } \\
\hline All US have federal regulations & Most have federal regulations \\
\hline Some have area designation & Some have local regulations \\
\hline Some have local regulations & Some have regional regulations \\
\hline
\end{tabular}


RQ6a. What other non-restrictive techniques are used to manipulate visitor flow and/or behavior?

The non-restrictive techniques were mainly about attracting visitors to the places management wanted them instead of forbidding or restricting them from the places they were not allowed. Techniques such as informing visitors in advance and on site were mentioned by most managers as well. The non-restrictive methods are shown in Table 10. Austrian managers generally try to steer away from using any restrictive techniques to manage their smaller visitation levels. Although rarely used, the most common management actions in Europe are limiting the number of visitors who can enter an area, charging a fee, guidance by ranger system, training special user groups, and training commercial user providers.

Table 10

Mitigating Visitor Use Impacts

\begin{tabular}{|l|l|}
\hline \multicolumn{1}{|c|}{ US } & \multicolumn{1}{c|}{ Austria } \\
\hline Inform/educate in advance & Enforce existing management plan \\
\hline On-site ranger education & On-site ranger education \\
\hline Monitor conditions & Monitor conditions \\
\hline Permits/licensing & Control access to Riparian areas \\
\hline
\end{tabular}

RQ7. What (if any) visitor monitoring procedures are in effect at this area?

The U.S. Forest Service managers reported various monitoring projects in their areas. The most popular monitoring techniques were condition monitoring of hot spots or invasive species, and visitor monitoring using the NVUM surveying method. The only monitoring methods mentioned by the Austrian managers were counting or estimation methods conducted mainly at visitor facilities on-site. Many had studies planned. 
RQ8. What are your thoughts on standardizing visitor use methods for communicating and/or collaborating on research efforts?

Managers generally reported the sources where they could obtain information on other frameworks and methods from other areas, but then explained that they usually did not have the time or personnel for extra research efforts. The sources from which the managers reported gathering the information they had on existing frameworks are shown in Table 11.

Table 11

Acquiring Knowledge about Other Management Frameworks

\begin{tabular}{|l|l|}
\hline \multicolumn{1}{|c|}{ US } & \multicolumn{1}{c|}{ Austria } \\
\hline Supervisor/colleague & Review literature \\
\hline Review literature & Supervisor/colleague \\
\hline Internet & \\
\hline Conferences & \\
\hline Visit other units & \\
\hline
\end{tabular}

RQ9. What are some possible constraints or limitations that must be addressed when collaborating internationally?

RQ9a. Why would international collaboration be beneficial and ultimately necessary in the future?

Although aware of the benefits of collaborative research and database efforts, overall the participating managers did not entertain the possibility of joining such a study in the near future because of various constraints. Most managers were hesitant to take on any more work, citing limited personnel and funding as reasons they would not be able to take on any new research 
projects, even though they answered positively when asked if they believed such processes could be beneficial. The summarized phenomena from the results that seemed significant are shown in Table 12.

Table 12

Summarized Results

\begin{tabular}{|l|l|}
\hline \multicolumn{1}{|c|}{ US } & \multicolumn{1}{c|}{ Austria } \\
\hline More focused on social & More focused on biological \\
\hline Larger scale, federal bureaucracy & More decentralized \\
\hline Activities involve driving, skiing & Cycling, fishing, Nordic skiing \\
\hline Hiking, boating, OHV & Hiking, fishing, agriculture use \\
\hline Impacts on soil and water & Impacts on wildlife \\
\hline Higher use, economic/social changes & Observation/estimates \\
\hline Educate and monitor & Manipulate setting and behavior \\
\hline Conflict expected & Conflict not an issue \\
\hline
\end{tabular}

RQ10. Why would international collaboration be beneficial and ultimately necessary in the future?

Using the Delphi method, similar ideas expressed in differing ways were merged to standardize the issues and motivations of the managers in the first round. With the issues normalized, the second round of questions were answered, and subsequently evaluated, resulting in a more comprehensive understanding of primarily the general range of recreational managers' job commonalities, differences, and also insight into the cause of these relationships. A fresh perspective on the same issue can reveal variables or insight that was not realized from the 
experiences occurring in their area. When two groups are vastly different at some levels, there can be an advantage in the sense that some aspects that one group is approaching empirically in their studies of specific situations, the other has already experienced heavily, thereby presenting the opportunity to exchange methods and experiences for new empirical findings and approaches.

The Delphi process was conceptually and structurally successful in this study and is recommended for further related research. The following purposes are especially appropriate:

- Exploring underlying assumptions on information leading to judgments,

- Prioritizing policies and other variables for management decisions,

- Identifying a common language for discourse among and across populations,

- Educating respondent groups on diverse and interrelated aspects of a topic, and

- Converging opinions on specific world-related issues (adapted from Delbecq, van de Ven, \& Gustafson, 1975).

The method is also adaptable and can be combined or compared with other studies, making further studies into its preliminary results easier to facilitate. The demand of visitors and the supply of the resources in each area vary due to numerous conditions that can be ecological, cultural, or managerial, among many others. 


\section{Chapter 5: Discussion}

Regardless of which definition is used, when something is said to have value, it is implied that this entity is held in esteem, possesses great significance, or provides great bounty for those affected by it. Even in the world of public nature recreation, the term is as multivariate-and therefore illusive-as its array of definitions in the English language. In the public land or recreation management field there are certainly precise, quantitative studies to be done on the natural resources, visitors, and other resources; but most initial studies on social dynamics must be qualitative. There is an unavoidable and necessary difference in opinion on how to measure and manage issues in this field from one location to the next, because each area has its own type and amount of various items to measure, including: natural features, history, demographics, and demands from users, just to name a few. The variance of opinions and the resources behind them expands with greater distance. This phenomena deems some things important for international communication that are normally taken for granted, such as social tolerance, governing policies, and local traditions.

Each area in the U.S. has different objectives and different levels of knowledge as to how the issues they face can be addressed. Europe is covered in protected areas of great-often confusing-diversity; Austria has 12 different types of protected land designations (Mose \& Weixlbaumer, 2006). This diversity makes it hard to calibrate any standard directives or frameworks. There are lots of data, methods, and insights used in Europe but studies are not linked; therefore, recreation and effects of outdoor activities remain poorly understood and documented.

There was an apparent juxtaposition between objectives in management considerations between a U.S. National Scenic Area and the Austrian Wildlife Reserve (Wildnisgebiet). The 
Austrian managements have taken the stance that, "the natural development of the wilderness area and the eco-systems within these areas, without human impact, have the highest priority." In contrast, the U.S. areas' managers stated their mission was, "to provide and protect for enhancement of scenic, cultural, recreational, and natural resources." These managers do not have the freedom to allow unrestricted use of a potentially-sensitive area for the duration of time needed to assess its vulnerability or carrying capacity because of the high visitation rate and dispersed backcountry use at many U.S. Forests. The damage caused by OHV use in some forests can account for this dilemma. Over the years, the USFS has issued policies as needed to protect its resources while still allowing the public to enjoy them.

Throughout its history, the USFS and its partners have developed systematic methods and frameworks to implement these policies. Although the Forest Service managers have the ideal standardized policies and methods provided by their centralized agency, there are still major constraints preventing the implementation of these methods into the management infrastructures at the individual forest level. The same frameworks can have vastly different results in seemingly similar areas because of the variety of local populations and user groups. Each area has unique resources and situations that must be methodically evaluated and monitored in accordance with the theoretically ideal situations laid out as policy in the USFS handbooks and the Federal Register. Although both countries have desires to protect the land, this contrast shows how different designations of public land can result in very different priorities when making management decisions specific to their on-site values or missions.

It took years and numerous sociological paradigm shifts for the U.S. to realize humans as part of the ecology of a landscape. The younger Austrian areas will have to let this idea seep in by its own means, through its now biological conservation-driven management systems. Sites 
for conservation and recreation were separate entities up until 30 years ago, and the majority of the current multi-use areas do not yet see the great numbers of users common in the U.S. Forests. Social carrying capacity literature is much more prevalent in the U.S., and represents a single, separate research topic; whereas in Austria it is synthesized into other, usually ecological, research.

It will be interesting when more crowding studies are done in Austria to see if their public has a higher tolerance for crowding because they are used to denser populations. It can be observed from this study, along with the corresponding literature, that Austrian managements are aware of the social value of their areas and the importance of providing infrastructure to foster meaningful experiences and community benefits. However, the research done to access the public preferences or responses is scarce and, again, incomparable between the existing site studies due to the lack of reliable systematic methodology. A recent study between the Netherlands, U.S., and Denmark described the progression of natural resource management toward integrated studies in three stages: "(1) Natural resources first, foremost and forever; (2) Natural resource management, for better or for worse, involves people; and (3) managing natural resources for valued people and ecosystem relationships” (J. J. Kennedy \& Koch, 2004, p. 497). Even in their socially-oriented studies, the bias in Austria is still eco-centric, in contrast to the U.S.'s anthropocentric bias (Burns et al, 2010). In other words, most Austrian studies on user preferences and crowding are conducted to anticipate negative impacts they might have on the resources, while most socially-oriented studies in the U.S. are entirely focused on the visitor's opinions, such as satisfaction, preferences, and so forth.

Any type of visitor impact can be exacerbated by certain bad behaviors, such as a dog off leash (Arnberger \& Hinterberger, 2003). Visitors can say one thing and do another, so it is more 
reliable to combine observation methods with the interviewing methods. In an Austrian urban park, people wanted to release dogs, so they adapted their behavior to match that preference (Arnberger \& Hinterberger, 2003). Many conflicts between users could have been avoided if particular behaviors were not introduced. Managers can even prioritize the satisfaction levels of user groups whose preferences are in tune with the area values. At the same time, they must keep in mind there will be impact caused by reaction behavior, such as displacement, from the groups that are not satisfied. It would behoove managers everywhere to use their visitors as a conservation tool.

Studies have shown that natural area visitors prefer a pristine environment; therefore, the concept of creating allies for protection through stewardship is an attainable one. A recent U.S. study even found that visitors preferred paying fees over closing or letting sites deteriorate (Absher et al., 2006). Social norms across groups might greatly differ in different areas, but the methods used to identify these norms are conducted at an individual level-so they are applicable in any area, which standardizes them and makes them more attractive for collaborative research studies.

The purpose for the establishment of all public areas studied was, to some degree, nature conservation. Austria is in more of a rehabilitative or restorative stage in most of their areas, as juxtaposed to the protective or sustainable stage in the U.S. In IUCN areas the main concentration is on protecting sensitive species, so it was no surprise that most Austrian areas in the first round Delphi in this study named specific species that were being affected, and named the activities that cause negative impacts in direct relation to the habitat or behavior changes it caused in the wildlife. This point of view was clearly driving one Austrian manager's answers in the second round, and could explain the seemingly paradoxical relationships that occurred; such 
as his against-the-pattern agreement with the statement that "recreation causes constant and severe impact" to the area even though his area has the lowest number of visitors of all areas in the study. From the perspective of wildlife behavior or habitat, any recurring use could be constant and severe.

Both Austrian and US area managers have some kind of policy in place to protect natural features from recreational or other types of use. Most public land managers are familiar with at least the concept of carrying capacity. Not knowing the capacity of areas where steady use already occurs is an issue for recreation managers in both countries. Before decisions are made on how to administer recreational use in an area, the amount of use an area can sustain must be determined.

History plays a large role in policy implementation. It is harder to establish new policies in an old government system. It was initially suspected that because of the lack of systematic methods and management frameworks in Austria the exchange between countries might heavily benefit them but would be a greater task to the U.S. managers who have to deconstruct their familiar policies, acts, or frameworks into separate actions and intentions in order for the comparisons to be made. At the conclusion of the study, however, there seemed to be more of a balance of benefits, as the USFS managers could gain useful information from the Austrian managers who faced some of the same challenges they experience (but on a larger scale) such as implementing wider, international policies into their management plans; dealing with less mitigated funding from their decentralized regional governments; less legal cases against them requiring a response-but also less ability to punish wrong-doers; dealing with a local base of users with a considerably longer stubborn tradition of recreation practices they must honor, and 
an average user base that includes large percentages of regular visitors from other countries all over Europe.

There are no federal policies, methods, or frameworks in Austria. Therefore, decisions about techniques and actions toward improving, creating, or monitoring recreation opportunities are made at a regional or local level. On the other hand, for U.S. Forest Managers, planning within the agency is tediously complex; management practices and objectives are closely scrutinized by both the public and U.S. courts. People and groups appeal for or object to environmental policies and forest regulations to such a degree that U.S. management frameworks are often established because of lawsuits about restrictions (Burns et al., 2010). The similar constraints and situations for the managers from both countries suggests partnerships or collaborations with other public land managers could, at the very least, provide insight. The continued expansion of protected areas will require a clear set of goals and an "increased investment in human resources, in the development of enterprises . . . in education, and in research aimed at producing improved means of management. But such an investment would be well repaid by human societies living in a better balance with their environment" (Harrison et al., 1982, p. 31). The bottom line for strategic partnerships is that there is strength in numbers, but a calibrated management framework is needed to collaborate efficiently.

Passing and implementing policy is difficult in both countries, but for different reasons. In Austria, new requirements for NP designation can be difficult to implement when they conflict with traditional behavioral patterns of recreation use, local knowledge, and so forth (Arnberger \& Hinterberger, 2003). It was not until the 1970s that recreation was recognized as a function of public green space in Austria, leaving public recreation managers to depend on funding bodies that have difficulty acknowledging its significance. Tourism replaced wood 
production as the main means of natural development, and the competing demands on forest functions meant no zones for planning recreation in Austria, and therefore, no frameworks on a national scope (Pröbstl et al., 2009). Decisions about techniques and actions toward improving, creating, or monitoring recreation opportunities are made at a regional or local level. Similarly across the Atlantic, for U.S. Forest Managers, planning within the agency is tediously complex; management practices and objectives are closely scrutinized by both the public and U.S. courts. People and groups appeal for or object to environmental policies and forest regulations to such a degree that U.S. management frameworks are often established because of lawsuits about restrictions (Burns et al., 2010).

It appears the two countries' systems are not so different in context or intent, just prioritization. Any new method created or policy passed will "depend on the ability of local permit administrators to understand and implement the new derivatives" (D. Brown, 2008). The USFS handbooks and policies are only a guide to the field; each site's management has its own identity and ways of achieving policy guidelines on the local or regional level—along with their own constraints. The management methods in the two countries face similar constraints overall, including (a) new and increasing recreational activities presenting new challenges, (b) strong public rights to land issues, (c) diverse expectations about the area's purpose and use, (d) difficulty obtaining research funding, and (e) additional demands or projects, such as collaboration, which add to already full workloads (Beir et al., 2007; Mann \& Absher, 2006; Pröbstl et al., 2009; Sample et al., 2007; Synge, 2004).

Establishing an efficient regulation system will take more time and funds, although both are already in short supply at most areas. Restrictive programs also call for monitoring and evaluating issued permits, requiring extra personnel, another resource also lacking in most areas. 
Visitor use in Austria is seen more in the light of providing opportunities and guiding visitor access rather than putting an emphasis on restrictions and limitations, as is unavoidable in the U.S. Even in the example of the heavily-used Biosphere Wienerwalt, the focus of research is on understanding the motivations behind visitors' behaviors that cause negative ecological impacts. The idea is to gain an understanding of what drives them to their actions, so the management can come up with alternative solutions to control or guide the use to a less-harmful place without restricting access.

Both countries would prefer to use non-restrictive techniques over the harsher use regulation systems, but the US Forests see enough visitors to degrade the natural quality of the land if not controlled. There are a creative variety of non-restrictive techniques in both Austria and the US. A popular value in Austrian public land management is that protected areas should not be seen as separate from their surroundings (Hennig, 2006). This idea benefits local regions and communities that would otherwise be isolated, by not only bolstering economies, but also accentuating pride and upkeep of local culture and landscapes. In the Styrian region around Gesäuse National Park, traditional farming in its unique Alpine meadows is permitted and desired by visitors, locals, and managers (Hasler \& Paar, 2008). Many area managements see the rise in tourism as an opportunity for "enlightened environmental education," or more stewardship from visitors, thanks to the interpretation opportunities provided at the protected areas' facilities (Synge, 2004, p. 24). They have the advantage of establishing certain desired values from the beginning, which in turn should lead to desired behaviors from their visitors. While the U.S. had naturalists like Teddy Roosevelt start the paradigm of conserving land for future generations of the public, Austria's protected areas were established in great part by local populations, coupled with environmental organizations and political decision-makers (Hasler \& 
Paar, 2008). These beginnings also explain why they would tend to have more of a trust that their visitors will follow the provided facilities and regulations. An innate public stewardship allows managers to focus more on interpretational and educational projects for visitor management, since there are no official legal ramifications for offenders or abusers as is the case in the U.S.

One crucial type of data managers should gather is information about their visitors' actions and movement throughout the area. Both Austria and the U.S. favor monitoring techniques for gathering this information. There are many survey methods and monitoring techniques available. It is really the researcher-manager relationship that enables efficient indicator variables and appropriate standards, however. Indicators that really do catch the attention of the policy- and decision-makers will be chosen not by those who advocate logical frameworks, but rather by the decision-makers themselves, because indicators chosen by those involved in the situation are perceived to be useful for monitoring something (Rutherford, 1998). This plan to inventory, measure, and monitor resources could be of substantial benefit to Austrian public land managers who are in need of a method to relate and measure the value of recreation for policy makers who have viewed recreation as the only official public forest function for the last three decades.

The terms and knowledge behind recreation management have not been standardized for international use, possibly because they have usually been coined on location and by necessity of that certain area. Even on a domestic basis there is a lack of communication and blanket research being done on certain issues because the terms and processes used to reach their results have no common ground on which to compare; therefore, few researchers have taken steps to support or refine their findings (H. P. Kennedy, 2004). U.S. Forest managers would be able to 
communicate recreation as a more important forest function among the many competing uses within their large agency if they had strong and understandable data from the process as well. The benefits of accumulating consistent data over longer periods of time would be numerous for any area, regardless of how many visitors, resources, or conflicts require management. The Austrian areas' total annual visitor use numbers have yet to match those of the US, but their numbers are rising; 400,000 visitors were counted at visitor centers in 2007 (Hasler \& Paar, 2008). It would be easier and more effective for areas with fewer visitors to develop plans to prevent potential negative impacts caused by the surge, rather than react and have to change undesirable patterns as they emerge. In order to predict use or behavior under certain situations, the cumulative use or behavior that has been occurring should be examined. If visitor count and behavior have not been recently measured in a specific area, the pattern found from a use study in another area can be predictive as long as the processes used to obtain those measurements are standardized. If there is no such methodology currently in place in the area, research efforts would yield a promising selection of published techniques that have been tested and evaluated for effectiveness. This could enable managers to build upon the proven methods to minimize time and error margins. Having easy access to a vast database of such research studies would not only keep managers from re-discovering the same limitations and insufficient models; it would provide a wider spectrum of methods and applied uses from which to choose the most appropriate techniques for their areas assessment.

Communication and collaboration seemed to be collective goals of many managers participating in the meeting; not only between regions and in the agency itself, but also with local stakeholders, recreation-related organizations, and even outreach to international affiliates and programs. They discussed blanket constraints the area managers face, such as implementing 
policy in their individual areas. The other popular topic was how to go about finding individual identities for their specific forest within the guidelines of the federal system policies (USDA, 2008b).

Establishing and marketing their identity to visitors is also very important to the Austrian Parks. Their greatest conflicts are when the newer directives or conservation guidelines contrast with national traditions, such as Alpinism, which is ten times older than the country's oldest National Park. A law was enacted in 1921 to protect an even longer tradition that people can "wander freely above the treeline." Upholding such traditions means managers must be cautious about any decisions to remove access rights (Bachleitner \& Zins, 1999; Hennig \& Laube, 2006; Wirth et al., 2006). Many activities are grandfathered into the protected areas' policies that would not be otherwise allowed. For example, anglers and fishermen that were recreating in the areas before they came under protection are still permitted to use the National Parks for their activities, but there are no new permits being issued, which will eliminate this undesirable use as time goes by. The similar constraints and situations for the managers from both countries suggest partnerships or collaborations with other public land managers could, at the very least, provide insight. The continued expansion of protected areas will require a clear set of goals and an "increased investment in human resources, in the development of enterprises ... in education, and in research aimed at producing improved means of management. But such an investment would be well repaid by human societies living in a better balance with their environment" (Harrison et al., 1982, p. 31). The bottom line for strategic partnerships is that there is strength in numbers, but a calibrated management framework is needed to collaborate efficiently. The extra effort it would take to develop a system upon which to communicate would be reciprocated in resulting benefits to each participating country (and site), as each would gain wider 
understanding and communication skills in their own areas, as well as wider recognition, more accessible research, and the ability to more easily and efficiently collaborate as a management system, and with other organizations.

Whether collaborating or comparing sites on a regional, national, or international level, there will be differences that apply. These variations give each site its own identity, which necessitates specific adaptations of a decision-making system. Initially, the biggest issue for the Austrian managers in the study was that they cannot adapt another country's frameworks or policies because of historical and technical differences. Austria actually has many restrictive measures in place for endangered species or rare wildlife, but they have not seen the use levels that require more regulatory measures, such as limiting visitor numbers or requiring reservations. On top of any obvious constraints, such as language and culture barriers, there was extra effort needed to widen the terms and parameters of research so as to be standardized and comparable.

Collaboration between the two country's managers would open a large research database of available methods, not necessarily to adapt, but to learn from, on a situational and methodological basis while they are forming their own. In making themselves more familiar with the current issues of U.S. Forests, the Austrian managers would be able to foresee what use patterns or impacts they might face as their visitation numbers rise. In exchange, the U.S. would be exposed to their fresh and inviting ideas surrounding visitor use management, and gain communication skills. Through making their Forests internationally relative they could then use the new practices they have learned with their own stakeholders, policy makers, and other external organizations or populations. Managers could also learn about the essence of maximizing their area's individual identities while adapting to federal policies. The constraints and inhibitions preventing this cooperation generally come from a disdain of standardization, or 
not seeing the potential value in putting the necessary effort forth to do so. By participating in such an effort, however, they would not only gain the benefits, but also the skills developed during the process, which would provide them with a more comprehensive knowledge of their own resources, values, and policies-after having had to dissect and rearrange them to fit into a uniform system. Undergoing the task of standardizing for the masses would, ironically, help managers of each area its individuality by better understanding how far they fall from the general consensus, and what distinctions set them apart.

"Culturally diverse populations may have varying values, and values influence other ...[therefore] it is important to study these values among increasingly diverse populations in a variety of contexts" (Li et al., 2006). The policies, goals, and objectives on which managers base their frameworks and actions must be derived from their individually personalized values for their areas through such a process. Just as the theatre industry is globally respected and collaborative, even across countries with clashing aesthetic cultures; the field of sustainable recreation must establish that kind of international relationship before receiving more universal understanding and respect. Collective efforts can be aided or executed by numerous organizations, from polling corporations to universities, but without full consideration and commitment from the managers, even the most significant and reliable data on paper could lack efficiency in the field. With rising use levels only predicted to go higher, it is no longer sufficient for managers to implement techniques in response to negative impacts. Continuous, systematic monitoring is needed in order to anticipate impacts in an area, and collaboration or communication with other managers is needed to have the stronger database supporting and relating the importance of those findings as part of the bigger picture-or at least a big enough picture for the policy makers, funding organizations, and visitors affecting the areas to 
understand. The observations from this study suggest that there is enough of a relationship between visitor use management initiatives in the two countries to proceed with bigger qualitative studies with more focused key concepts in order to identify common indicators that would expedite the communication process, and lead to more collaborative studies and wider database cooperation. 


\section{References}

Absher, J. D., Graefe, A. R., \& Burns, R. C. (2006, September). Monitoring public reaction to the US Forest Service Recreation Fee Program. In D. Siegrist, C. Silvas, M. Hunsiker, \& S. Iten, (Eds.), Proceedings from the ICMMVF '06: Exploring the nature of management. The 3rd international conference on monitoring and management of visitor flows in recreational and protected areas. Rapperswil, Switzerland.

Absher, J. D., \& Lee, R. (1981). Density as an incomplete cause of crowding in back-country settings. Leisure Sciences, 5(4), 231-247.

Aikoh, T., Arnberger, A., Shoji, Y., \& Mieno, T. (2008, October). Comparison of motivations and crowding preferences between Austrian and Japanese urban forest visitors. In A. Raschi \& S.Trampetti (Eds.), Management for protection and sustainable development. Proceedings of the 4th international conference on monitoring and management of visitor flows in recreational and protected areas (p. 65), Montecatini Terme, Italy.

Altman, I. (1978). Crowding: Historical and contemporary trends in crowding research. In A. Baum \& Y. Epstein (Eds.), Human response to crowding (pp. 3-29). New York, NY: John Wiley \& Sons.

Archer, B. (1980). Forecasting demand: Qualitative and intuitive techniques. Tourism Management, 1(1), 5-12.

Arnberger, A., \& Brandenburg, C. (2002). Besucher-monitoring im Nationalpark Donau-Auen Niederösterreichischer Anteil [Visitor-monitoring in the Danube Floodplains National Park-Northern Austria]. Vienna, Austria: BOKU-University of Natural Resources and Applied Life Sciences.

Arnberger, A., \& Eder, R. (2007). Monitoring recreational activities in urban forests using longterm video observation. Forestry, 80(1), 1-15.

Arnberger, A., \& Grant, N. (2008). Site specific studies on recreational use in forests. In T. Sievänen, A. Arnberger, J. Dehez, N. Grant, F. S. Jensen, \& H. Skov-Petersen (Eds.), Forest recreation monitoring-A European perspective (pp. 43-58). Helsinki, Finland: Working Papers of the Finnish Forest Research Institute.

Arnberger, A., \& Haider, W. (2007a). Would you displace? It Depends! A multivariate approach to intended displacement from an urban forest trail. Journal of Leisure Research, 39(2), 345-365.

Arnberger, A., \& Haider, W. (2007b). A comparison of global and actual measures of perceived crowding of urban forest visitors. Journal of Leisure Research, 39(4), 668-685. 
Arnberger, A., Haider, W., \& Brandenburg, C. (2005). Evaluating visitor monitoring techniques: A comparison of counting and video observation data. Environmental Management, 36(2), 317-327.

Arnberger, A., \& Hinterberger, B. (2003). Visitor monitoring methods for managing public use pressures in the Danube Floodplains National Park, Austria. Journal for Nature Conservation, 11, 260-267.

Arnberger, A., \& Mann, C. (2008). Crowding in European forests: A review of recent research and implications for forest management and policy. Forestry, 81(4), 599-671.

Aspinall, R. (2004). Modeling land use change with generalized linear models-A multi-model analysis of change between 1860 and 2000 in Gallatin Valley, Montana. Journal of Environmental Management, 72(1-2), 91-96.

Bachleitner, R., \& Zins, A. (1999). Cultural tourism in rural communities: The residents' perspective. Journal of Business Research, 14, 199-209.

Barja, I., Silván, G., Rosellini, S., Piñeire, A., Gonzáles-Gil, A., Camacho, L., \& Illera, J. (2007). Stress physiological responses to tourist pressure in a wild population of European pine marten. Journal of Steroid Biochemistry and Molecular Biology, 104, 136-142.

Baum, A., \& Epstein, Y. (1978). Human response to crowding. New York, NY: John Wiley \& Sons.

Bean, M. J., Fitzgerald, S., \& O'Connell, M. A. (1991). Reconciling conflicts under the Endangered Species Act: The habitat conservation planning experience. Washington, DC: World Wildlife Fund.

Becker, R. H., Niemann, B. J., \& Gates, W. A. (1981). Displacement of users within a river system: Social and environmental trade-offs. Madison: University of Wisconsin Press.

Behrens, D., Bednar-Friedl, B., \& Getzner, M. (2009). Sustainable management of an alpine national park: Handling the two-edged effect of tourism. Heidelberg, Germany: SpringerVerlag.

Beier, U., Degerman, E., Melcher, A., Rogers, C., \& Wirlöf, H. (2007). Processes of collating a European fisheries database to meet the objectives of the European Union Water Framework Directive. Fisheries Management and Ecology, 14(6), 407-416.

Bell, S., Tyrvänen, L., Sievänen, T., Pröbstl, U., \& Simpson, M. (2007). Outdoor recreation and nature tourism: A European perspective. Living Review Landscape Resources, 1(2), 1-45.

Bishop, I. D., Wherrett, J. R., \& Miller, D. R. (2001). Assessment of path choices on a country walk using a virtual environment. Landscape and Urban Planning, 52, 225-237. 
Bogdan, R., \& Bilken, S. K. (1992). Qualitative research for education: An introduction to theory and methods (2nd ed.). Boston, MA: Allyn and Bacon.

Bourke, L., \& Luloff, A. E. (1994). Attitudes toward the management of nonindustrial private forest land. Society \& Natural Resources, 7(5), 445-457.

Brandenburg, C., \& Ploner, A. (2002). Models to predict visitor attendance levels and the presence of specific user groups. In A. Arnberger, C. Brandenburg, \& A. Muhar (Eds.), Monitoring and management of visitor flows in recreational and protected are as (pp. 166-172). Vienna, Austria: Institute for Landscape Architecture and Landscape Management.

Brans, J. P., Mareschal, B., \& Vincke, P. (1986). How to select and how to rank projects: The PROMETHE method. European Journal of Operational Research, 24, 228-238.

Brown, D. (2008). The lowdown on the new Forest Service permitting directives. Retrieved from America Outdoors website:

http://www.americaoutdoors.org/america_outdoors/files/html-article/ForestSvc.htm

Brown, P., \& Hunt, J. (1969). The influence of information signs on visitor distribution and use. Journal of Leisure Research, 1(1), 79-62.

Bultena, G., Field, D., Womble, P., \& Albrecht, D. (1981). Closing the gates: A study of backcountry use limitation at Mt. McKinley National Park. Leisure Sciences, 4(3), 249-267.

Burns, R. C., Arnberger, A., \& von Ruschkowski, E. (2010). Social carrying capacity challenges in parks, forests, and protected areas: An examination of trans-Atlantic methodologies and practices. International Journal of Sociology, 40(3), 30-50.

Burns, R. C., \& Graefe, A. R. (2006, September). Segmentation of outdoor recreationists: A comparison of recreationists' perceptions of importance and satisfaction across activities. In D. Siegrist, C. Silvas, M. Hunsiker, \& S. Iten (Eds.), Proceedings from the ICMMVF '06: Exploring the nature of management. The 3rd international conference on monitoring and management of visitor flows in recreational and protected areas. Rapperswil, Switzerland.

Burns, R. C., Graefe, A. R., \& Absher, J. D. (2009). Carrying capacity analysis for Grand Mesa, Uncompahgre and Gunnison National Forests (U.S. Forest Service, Scope of work document). Portland, OR: U.S. Department of Agriculture, Forest Service, Pacific Northwest Forest and Range Experiment Station.

Cole, D. (2001). Visitor use density and wilderness experiences: A historical review of research. In W. Wayne \& D. Cole (Eds.), Visitor use density and wilderness experience (pp. 1120). Ogden, Utah: U.S. Department of Agriculture, Forest Service. 
Cole, D., \& Daniel, T. (2003). The science of visitor management in parks and protected areas: From verbal reports to simulation models. Journal of Nature Conservation, 11, 269-277. doi:10.1078/1617-1381-00058

Collins, S., \& Brown, H. (2007). The growing challenge of managing outdoor recreation. Journal of Forestry, 105(7), 371-375.

Cordell, H. K., Hoover, A. P., Super, G. R., \& Manning, C. H. (1999). Adding human dimensions to ecosystem-based management of natural resources. In K. Cordell \& J. Bergstrom (Eds.), Integrating social sciences with ecosystem management: Human dimensions in assessment, policy, and management (pp. 1-12). Champaign, IL: Sagamore.

Creel, S., Fox, J., Hardy, A., Sands, J., Garrott, B., \& Peterson, R. (2002). Snowmobile activity and glucocorticoid stress responses in wolves and elk. Conservation Biology, 16, 809814.

Czech, B. (2000). Economic associations among causes of species endangerment in the United States. Bioscience, 50, 593-601.

Daily, G. C., \& Ehrlich, P. R. (1992). Population, sustainability, and earth's carrying capacity. Bioscience, 42(10), 761-771.

Dalkey, N. D., \& Helmer, O. (1963). An experimental application of the Delphi method to the use of experts. Management Science, 9(3), 458-467.

Daniel, T. C., \& Boster, R. S. (1976). Measuring landscape aesthetics: The scenic beauty estimation method (U.S. Forest Service research paper RM-167). Fort Collins, CO: U.S. Department of Agriculture, Forest Service, Rocky Mountain Forest and Range Experiment Station.

Degerman, E., Beier, U., Breine, J., Melcher, A., Quataert, P., Rogers, C., . . Simoens, I. (2007). Classification and assessment of degradation in European running waters. Fisheries Management and Ecology, 14, 417-426.

Dehez, J., Colson, V., Mann, C., \& Sievanen, T. (2008). State of art of recreation inventories in European countries. In T. Sievänen, A. Arnberger, J. Dehez, N. Grant, F. S. Jensen, \& H. Skov-Petersen (Eds.), Forest recreation monitoring-A European perspective (pp. 34-69). Helsinki, Finland: Working Papers of the Finnish Forest Research Institute.

Delbecq, A., Van de Ven, A., \& Gustafson, D. (1975). Group techniques for program planning. Glenview, IL: Scott, Foresman, and Co.

Dennis, D. F. (1998). Analyzing public inputs to multiple objective decisions on national forests using conjoint analysis. Forest Science, 44, 421-429. 
Deutscher Sportbund (Ed.). (2001). Natura2000 und sport, Ein leitfaden zum umgang mit der Fauna-Flora-Habitat-Richtlinie und der Vogelschutz Richtlinie [Natura2000 and sport, A Guide to dealing with the Fauna-Flora-Habitat Directive and Wild Birds Directive], Frankfurt, Germany: Author.

Dey, I. (1993). Qualitative data analysis: A user friendly guide for social scientists. London, England: Routledge and Kegan Paul.

Ditton, R. B., Fedler, A. J., \& Graefe, A. R. (1983). Factors contributing to perceptions of recreational crowding. Leisure Sciences, 5(4), 273-288.

Dogan, H. (1989). Forms of adjustment: Socio-cultural impacts of tourism. Annals of Tourism Research, 16(2), 216-236. doi:10.1016/0160-7383(89)90069-8

Donnelly, M. P., Vaske, J. J., Whittaker, D., \& Shelby, B. (2000). Toward an understanding of norm prevalence: A comparative analysis of 20 years of research. Environmental Management, 25, 403-414. doi:10.1007/s002679910032

Dyck, H., \& Emery, G. (1970). Social futures: Alberta 1970-2005. Alberta, Edmonton, Canada: Human Resources Research Council of Alberta.

English, D. B. M., Kocis, S. M., Cordell, H. K., \& Green, G. (2006, September). Estimating recreation market share for national forests. In D. Siegrist, C. Silvas, M. Hunsiker, \& S. Iten (Eds.), Proceedings from the ICMMVF '06: Exploring the nature of management. The 3rd international conference on monitoring and management of visitor flows in recreational and protected areas (pp. 389-390). Rapperswil, Switzerland: University of Applied Sciences. Retrieved from http://www.wsl.ch/mmv3/call/MMV3_proceedings.pdf

European Commission (Ed.). (2000). Natura2000—Gebietsmanagment [Natura2000-Area Management] Die Vorgaben des Artikels 6 der HabitatRichtlinie 92/43/EWG [Provisions of Article 6 of the Habitat Directive], 52.

European Communities (EC). (2002). Accounts for recreational and environmental functions of forests: Results of pilot applications. Luxembourg: Publications Office of the European Union.

European Communities (EC). (2003). Sustainable forestry and the European Union: Initiations for the European Commission. Luxembourg: Publications Office of the European Union.

European Union (EU). (1979). Directive on the conservation of natural habitats and of wild fauna and flora (The European Council Directive 92/43/EEC). Amtsblatt der Europäischen Gemeinschaft Reihe, 103, 1-6. 
European Union (EU). (1992). Directive on the conservation of wild birds (The European Council Directive 79/409/EEC). Amtsblatt der Europäischen Gemeinschaft Reihe, 206, 750 .

European Union (EU). (2000). Directive establishing a framework for community action in the field of water policy. Brussels, Belgium: The European Parliament.

Faulkner, S. (2004). Urbanization impacts on the structure and function of forested wetlands. Urban Ecosystems, 7, 89-106.

Ferguson, I. S. (1996). Sustainable forest management. Melbourne, Australia: Oxford University Press.

Freidmund, W. A., Vaske, J. J., Donnelly, M. P., \& Miller, T. A. (2002). Using video surveys to access dispersed back-country visitor norms. Leisure Sciences, 24, 349-362.

Gearing, C., Swart, W., \& Var, T. (1976). Planning for tourism development: Quantitative approaches. New York, NY: Praeger.

Gentin, S., Jensen, F., Bernasconi, A., Granet, A.-M., Kerckhove, G., \& Kokouris, E. (2008). Outdoor recreation in forest policy documents and legislation. In T. Sievänen, A. Arnberger, J. Dehez, N. Grant, F. S. Jensen, \& H. Skov-Petersen (Eds.), Forest recreation monitoring-A European perspective (pp.14-33). Helsinki, Finland: Working Papers of the Finnish Forest Research Institute.

Gergel, S. E., Turner, M. G., Miller, J. R., Melack, J. M., \& Stanley, E. H. (2002). Landscape indicators of human impact to riverine systems. Aquatic Sciences, 64, 118-128.

Getzner, M. (2003). The economic impact of national parks: The perception of key actors in Austrian national parks. International Journal of Sustainable Development, 6(2), 183 202.

Glasson, J., Godfrey, K., \& Goodey, B. (1995). Toward visitor impact management: Visitor impacts, carrying capacity and management responses in Europe's historic towns and cities. Aldershot, England: Ashgate.

Glück, P. (1996). Gestion durable et évolution législative et réglementaire en Europe [Sustainable management and legislative and regulatory developments in Europe]. Revue Forestiére Française, 1996, 137-151.

Graefe, A. R., Kuss, F. R., \& Vaske, J. J. (1990). Visitor impact management: The planning framework. Washington DC: National Parks and Conservation Association.

Green, H., Hunter, C., \& Moore, B. (1990). Assessing the environmental impact of tourism development using the Delphi technique. Tourism Management, 11, 111-120. 
Green, M. J. B., \& Paine, J. (1997, November). State of the world's protected areas at the end of the 20th century. Proceedings from IUCN World Commission on Protected Areas Symposium on Protected Areas in the 21st century: from Islands to Networks (pp. 1-35). Albany, Australia.

Grove, J. M. (1999). Tools for exploring new approaches in human ecosystem and landscape research: Geographic information systems (GIS), remote sensing, and computer modeling. In K. Cordell \& J. Bergstrom (Eds.), Integrating social sciences with ecosystem management: Human dimensions in assessment, policy, and management (pp. 219-236). Champaign, IL: Sagamore.

Gupta, U., \& Clarke, R. (1996). Theory and applications of the Delphi technique: A bibliography (1975-1994). Technological Forecasting and Social Change, 53(2), 185-211.

Hammer, T., \& Siegrist, D. (2008). Protected areas in the Alps-The success factors of naturebased tourism and the challenge for regional policy [Special issue]. Ecological Perspectives for Science and Society, 17, 152-160.

Harrison, J., Miller, K. R., \& McNeely, J. A. (1982). The world coverage of protected areas: Developmental goals and environmental needs. In J. McNeely \& R. Kenton (Eds.), National parks, conservation, and development: The role of protected areas in sustaining society (pp. 24-33). Washington, DC: Smithsonian Institution Press.

Hasler, M. V., \& Paar, D. M. (Eds.). (2008). Bundesministerium für Landwirtschaft und Forstwirtschaft, Umwelt und Wasserwirtschaft, Österreich [Federal Ministry for Land and Forest Management, Environment and Water Management, Austria]. Österreichs Nationalparks laden ein [Welcome to Austria's National Parks] (Collaborative brochure, 46 p.). Vienna, Austria: AV+Astoria Druckzentrum GmbH.

Hasson, F., Keeney, S., \& McKenna, H. (2000). Research guidelines for the Delphi survey technique. Journal of Advanced Nursing, 32(4), 1008-1015.

Heberlein, T. A., Alfano, G., \& Ervin, L. H. (1986). Using a social carrying capacity model to estimate the effects of marina development at the Apostle Islands National Lakeshore. Leisure Sciences, 8, 257-274.

Hein, T., Blaschke, A. P., Haidvogl, G., Hohensinner, S., Kucera-Hirzinger, V., Muhar, S., Preiner S., . . Zsuffa, I. (2006). Optimised management strategies for the Biosphere Reserve Lobau, Austria-Based on a multi criteria decision support system: Using ecohydrological model approaches. Ecohydrology and Hydrobiology, 6, 25-36.

Helmer, O. (1967). Analysis of the future: The Delphi method. Santa Monica, CA: Rand.

Hendee, J. C., Catton, W. R., Jr., Marlow, L., \& Brockman, C. F. (1968). Wilderness users in the Pacific Northwest-Their characteristics, values and management preferences (U.S. 
Forest Service Research Paper PNW-61). Portland, OR: U.S. Department of Agriculture, Forest Service, Pacific Northwest Forest and Range Experiment Station.

Hennig, S. (2006, September). Going ahead: From visitor monitoring to recreational use monitoring-The example of the EU regional recreation area Berchtesgaden National Park/Salzburger Kalkhochalpen. In D. Siegrist, C. Silvas, M. Hunsiker, \& S. Iten (Eds.), Proceedings from the ICMMVF '06: Exploring the nature of management. The 3rd international conference on monitoring and management of visitor flows in recreational and protected areas (pp. 322-328). Rapperswil, Switzerland.

Hennig, S., \& Laube, M. (2006). Besuchermonitring in Nationalparken: Eine Bestandsaufname in Deutschland, Oesterreich und der Schweiz [Visitor monitoring in National Parks: An inventory in Germany, Austria and Switzerland]. Standort, 4, 199-204.

Heywood, J. (1993). Behavioral connections in higher density, day use wild land/urban recreation settings: A preliminary case study. Journal of Leisure Research, 25, 39-52.

Hockings, M. (1997). Evaluating management effectiveness: A framework for evaluating management of protected areas. IUCN Working Group on Management Effectiveness ( $\mathrm{p}$. 78). Washington, DC: IUCN World Commission on Protected Areas.

Hohensinner, S., Jungwirth, M., Muhar, S., \& Habersack, H. (2005). Historical analyses: A foundation for developing and evaluating river-type specific restoration programs. International Journal of River Basin Management, 3(2), 89-96.

Holbrook, C., McGee, D., Walsh, J., \& Schiff, G. (Eds.). (2008). Forest Service communication plan: Federal Register notice: Final directives for the special uses handbook and manual outfitting and guiding administration. U.S. Department of Agriculture, Forest Service.

Holdgate, M. W. (1984). The need for research on environmental impact assessment. In R. Roberts \& T. Roberts (Eds.), Planning and ecology (pp. 439-455). London, England: Chapman and Hall.

International Institute for Sustainable Development (IISD). (1993). Indicators for sustainable management of tourism: Report of the international working group on indicators of sustainable tourism to the Environment Committee', World Tourism Organization. Winnipeg, Manitoba, Canada: Author.

International Symposium on Society and Resource Management (ISSRM). (2008, June). 14th Annual Conference: People and Place: Linking Culture and Nature, Burlington, Vermont.

International Union for Conservation of Nature and Natural Resources (IUCN). (1993). Parks for life: Report of the IV World Congress on national parks and protected areas (pp. viii260). Gland, Switzerland: IUCN. 
International Union for Conservation of Nature and Natural Resources (IUCN) Commission on National Parks and Protected Areas (1982). In J. McNeely \& R. Kenton (Eds.), National Parks, conservation, and development: The role of protected areas in sustaining society (pp. 47-53). Washington, DC: Smithsonian Institution Press.

International Union for Conservation of Nature and Natural Resources (IUCN), World Commission on Protected Areas (WCPA), \& World Conservation Monitoring (WCM) Center. (1994). Guidelines for protected area management categories. Gland, Switzerland: IUCN.

Irland, L. C. (1979). Wilderness economics and policy. Lexington, KY: D.C. Heath.

Kajala, L., Almik, A., Dahl, R., Dikšaite, L, Erkkonen, J., Fredman, P., . . Wallsten, P. (2007). Visitor monitoring in nature areas $-A$ manual based on experiences from the Nordic and Baltic countries. Bromma, Sweden: The Swedish Environmental Protection Agency.

Karlin, R., Epstein, Y., \& Aiello, J. (1978). A setting-specific analysis of crowding. In A. Baum \& Y. Epstein (Eds.), Human response to crowding (pp. 165-179). New York, NY: John Wiley \& Sons.

Kaynak, E., Bloom, J., \& Leibold, M. (1994). Using the Delphi technique to predict future tourism potential. Marketing Intelligence \& Planning, 12(7), 18-29.

Kaynak, E., \& Marandu, E. (2006). Tourism market potential analysis in Botswana: A Delphi study. Journal of Travel Research, 45, 227-237.

Kennedy, H. P. (2004). Enhancing Delphi research: Methods and results. Journal of Advanced Nursing, 45(5), 504-511.

Kennedy, J. J., \& Koch, N. E. (2004). Viewing and managing natural resources as humanecosystem relationships. Forest Policy and Economics, 6, 497-504.

Kibedi, G. (1981). Future trends in international tourism. Tourism Review, 36(1), 3-6.

Knetsch, J. L., \& Davis, R. K. (1966). Economic methods of measuring the value of recreation. In A. Kneese \& S. Smith (Eds.), Water research (pp. 125-142). Baltimore, MD: Johns Hopkins Press.

Knudson, R. (1999). Using cultural resources to enhance ecosystem management. In K. Cordell \& J. Bergstrom (Eds.), Integrating social sciences with ecosystem management: Human dimensions in assessment, policy, and management (pp. 129-140). Champaign, IL: Sagamore.

Landeta, J. (2005). Current validity of the Delphi method in social sciences. Technological Forecasting and Social Change, 73, 467-482. 
Landeta, J., Matey, V., \& Ruiz, O. (2002). Alimentación de modelos cuantitativos con información subjetiva: aplicación Delphi en la elaboración de un modelo de imputación del gasto turístico individual en Catalunya [Quantitative models with subjective information: Delphi application to develop a model for changing individual tourist expenditures in Catalonia]. Questiö, 26(1-2), 175-196.

Legore, S. (1984). Experience with environmental impact assessment procedures in the USA. In R. Roberts \& T. Roberts (Eds.), Planning and ecology (pp. 103-112). London, England: Chapman and Hall.

Leino, H. (2006). Citizen participation and the dynamics of urban planning. Retrieved from http://aeta.uta.fi/pdf/951-44-6566-0.pdf

Leujak, W. (2007). Visitor perceptions and the shifting social carrying capacity of South Sinai's coral reef. Environmental Management, 39(4), 472-489.

Lexer, W., Brandenburg, C., Heckl, F., Muhar, A., Reimoser, F., \& Zink, R. (2006, September). Participatory processes and participatory research-a tool for conflict identification and development of management decisions. In D. Siegrist, C. Silvas, M. Hunsiker, \& S. Iten (Eds.), Proceedings from the ICMMVF '06: Exploring the nature of management. The $3 r d$ international conference on monitoring and management of visitor flows in recreational and protected areas. Rapperswil, Switzerland.

Li, C.-L., Zinn, H. C., Chick, G. E., Absher, J. D., \& Graefe, A. R. (2006). Segmentation of visitor's cross-cultural values in forest recreation. In D. Siegrist, C. Silvas, M. Hunsiker, \& S. Iten (Eds.), Proceedings from the ICMMVF '06: Exploring the nature of management. The 3rd international conference on monitoring and management of visitor flows in recreational and protected areas. Rapperswil, Switzerland.

Lime, D. W., \& Stankey, G. H. (1971, October). Carrying capacity: Maintaining outdoor recreation quality. In E. Larson (Ed.), The forest recreation symposium, State University of New York College of Forestry (pp. 174-184). Durham, NH: U.S. Department of Agriculture, Forest Service, Northeastern Forest Experiment Station.

Linstone, H., \& Turoff, M. (1975). The Delphi method: Techniques and applications. Reading, MA: Addison-Wesley.

Loo, R. (2002). The Delphi method: A powerful tool for strategic management. Policing: An International Journal of Police Strategies and Management, 25(4), 762.

Louviere, J. J., \& Timmermans, H. J. P. (1990). Stated preference and choice models applied to recreation research: A review. Leisure Sciences, 12, 9-32.

Mackenzie, J. (1993). A comparison of contingent preference models. American Journal of Agricultural Economics, 75, 593-603. doi:10.2307/1243566 
Magill, A. W. (1970). Five California campgrounds' conditions improve after 5 years of recreational use (U.S. Forest Service Research Paper PSW-62). Broomall, PA: U.S. Department of Agriculture, Forest Service, Pacific Southwest Forest and Range Experiment Station.

Mann, C., \& Absher, J. D. (2006, September). An improved methodological approach to recreation conflict analysis in the Black Forest. In D. Siegrist, C. Silvas, M. Hunsiker, \& S. Iten (Eds.), Proceedings from the ICMMVF '06: Exploring the nature of management. The 3rd international conference on monitoring and management of visitor flows in recreational and protected areas. Rapperswil, Switzerland.

Manning, R. E. (1999a). Crowding and carrying capacity in outdoor recreation: From normative standards to standards of quality. In E. L. Jackson \& T. L Burton (Eds.), Leisure studies: Prospects for the 21 st century (pp. 323-334). State College, PA: Venture.

Manning, R. E. (1999b). Studies in outdoor recreation: Search and research for satisfaction (2nd ed.). Corvallis: Oregon State University Press.

Manning, R. E. (2007). Parks and carrying capacity: Commons without tragedy. Washington, DC: Island Press.

Manning, R. E., \& Lawson, S. R. (2002). Carrying capacity as 'informed judgement:' The values of science and the science of values. Environmental Management, 30(2), 157-168.

Manning, R. E., Lime, D. W., Freimund, W. A., \& Pitt, D. G. (1996). Crowding norms at frontcountry sites: A visual approach to setting standards of quality. Leisure Sciences, 18(1), $39-59$.

Manning, R. E, Lime, D. W., \& Hof, M. (1996). Social carrying capacity of natural areas: Theory and application in the US National Parks. Natural Areas Journal, 16, 118-127.

Manning, R. E., Lime, D. W., Hof, M., \& Freimund, W. A. (1995). The visitor experience and resource protection (VERP) process: The application of carrying capacity to Arches National Park. The George Wright Forum, 12(3), 41-55.

Manning, R. E., Valliere, W. A., Lawson, S. R., Newman, P., Burduk, M., Laven, D., .. . Wang, B. (2004). Development and application of carrying capacity frameworks for parks and protected areas. In Global challenges of parks and protected area management: Proceedings of the 9th ISSRM (pp. 373-384). Sassari, Italy: Carlo Delfino.

Manning, R. E., Valliere, W. A., Wang, B., Lawson, S. R., \& Newman, P. (2006). Estimating day use social carrying capacity in Yosemite National Park. Burlington, VT: Wilfrid Laurier University Press.

Martin, S. R., McCool, S. F., \& Lucas, R. C. (1989). Wilderness campsite impacts: Do managers and visitors see them the same? Environmental Management, 13, 623-629. 
McCarthy, P. E., \& Dower, M. (1967). Recreation conservation and development-An exercise in the process of decision making. Journal of the Town Planning Institute, 53(3), 99-105.

McCool, S. F., Lime, D. W., \& Anderson, D. (1977). Simulation modeling as a tool for managing river recreation. In Proceedings from River Recreation Management and Research Symposium (U.S. Forest Service General Technical Report NC-28). St. Paul, MN: U.S. Department of Agriculture, Forest Service, North Central Forest Experiment Station.

McCool, S. F., \& Moisey, R. N. (1996). Monitoring resident's attitudes toward tourism. Tourism Analysis, 1, 29-37.

McCormack, A., \& O’Leary, T. (1995). A performance approach to the assessment of the aesthetic resources of forest parks by landscape experts. In P. Hyttinen, A. Kahkonen, \& P. Deli (Eds.), Multiple-use and environmental values in forest planning. European Forest Institute Proceedings (No. 4, pp. 153-168).

McNeely, J. A., \& Thorsell, J. W. (1992). Guidelines: Development of national parks and protected areas for tourism. Madrid, Spain: World Tourism Organization.

Miller, G. (2001). The development of indicators for sustainable tourism: Results of a Delphi survey of tourism researchers. Tourism Management, 22, 351-362.

Miller, L. E. (2006, October). Determining what could/should be: The Delphi technique and its application. Paper presented at the 2006 annual meeting of the Mid-Western Educational Research Association, Columbus, Ohio.

Mohl, A. (2004, May). LIFE river restorations in Austria. Proceedings from the NCRR '04: The 3 rd European conference on river restoration 2004. Zagreb, Croatia.

Mose, I., \& Weixlbaumer, N. (2006, September). Protected areas as a tool for regional development? In D. Siegrist, C. Clivaz, M. Hunziker, \& S. Iten (Eds.), Proceedings from the ICMMVF '06: Exploring the nature of management. The 3rd international conference on monitoring and management of visitor flows in recreational and protected areas. Rapperswil, Switzerland.

Muhar, A., Arnberger, A., \& Brandenburg, C. (2002). Methods for visitor monitoring in recreational and protected areas: An overview. In A. Arnberger, C. Brandenburg, \& A. Muhar (Eds.), Monitoring and management of visitor flows in recreational and protected areas (pp. 166-172). Vienna, Austria: Institute for Landscape Architecture and Landscape Management.

Muhar, A., Schauppenlehner, T., \& Brandenburg, C. (2006, September). Trends in Alpine tourism: The mountaineers' perspective and consequences for tourism strategies. In D. Siegrist, C. Silvas, M. Hunsiker, \& S. Iten (Eds.), Proceedings from the ICMMVF '06: 
Exploring the nature of management. The 3rd international conference on monitoring and management of visitor flows in recreational and protected areas. Rapperswil, Switzerland.

Muhar, A., Zemann, R., \& Lengauer, M. (1995). Permanent time-lapse video recording for the quanification of recreational activities. Proceedings Decision Support-2001, 1, 219-229.

Mullen, P. (2003). Delphi: Myths \& realities. Journal of Health Organisation and Management, $17(1), 37$.

Müller, H. (1995). Der mensch im lebensraum von tieren: Beispiel tourismus und freizeitsport [Men in the living space of animals: The example of tourism and leisure sport]. Der Ornithologishe Beobachter [The Ornithological Observer], 92, (3).

Müllner, A., Linsenman, K., \& Wikelski, M. (2004). Exposure to ecotourism reduces survival and effects stress response in hoatzin chicks (Opisthocomas hoazin). Biological Conservation, 118, 549-558.

Multiple-use and Sustainable-yield Act of 1960, Pub. L. No. 86-5174, Stat. 215, 16 U.S.C. (1960).

Nielsen, J. M., Shelby, B., \& Haas, J. E. (1977). Sociological carrying capacity and the last settler syndrome. The Pacific Sociological Review, 20(4), 568-581.

Oberdorff, T., Pont, D., Hugueny, G., \& Porcher, J. (2002). Development and evaluation of a fish-based index (FBI) for the assessment of "river health" in France. Freshwater Biology, 47, 1720-1734.

Okoli, C., \& Pawlowski, S. D. (2004). The Delphi method as a research tool: An example, design considerations and applications. Information \& Management, 42, 15-29.

Olson, D. M., \& Dinerstein, E. (1998). The global 200: A representative approach to conserving the earth's most biologically valuable ecoregions. Conservation Biology, 12, 502-515.

O’Riordan, T., \& Sewell, W. R. D. (1981). From project appraisal to policy review. In T. O’Riordan, \& W. R. D. Sewell (Eds.), Project appraisal and policy review (pp. 1-28). New York, NY: John Wiley \& Sons.

Pigram, J., \& Jenkins, J. (1999). Outdoor recreation management. New York, NY: Routledge.

Pont, D., Hugueny, B., \& Rogers, C. (2007). Development of a fish-based index for the assessment of river health in Europe: The European Fish Index. Fisheries Management and Ecology, 14, 427-439.

Pregernig, M. (2001). Values of forestry professionals and their implications for the applicability of policy instruments. Scandanavian Journal of Forest Research, 16(3), 278-288. 
Prentice, R. C., Witt, S. F., \& Wydenbach, E. G. (1994). The endearment behavior of tourists through their interaction with the host community. Tourism Management, 15(2), 126-136.

Pröbstl, U. (2003). Natura 2000: The influence of the European directives on the development of nature-based sport and outdoor recreation in mountain areas. Journal for Nature Conservation, 11, 340-345.

Pröbstl, U., Elands, B. H. M., \& Wirth, V. (2009). Forest recreation and nature tourism in Europe: Context, history, and current situation. In S. Bell, M. Simpson, L. Tyrväinen, T. Sievänen, \& U. Pröbstl (Eds.), European forest recreation and tourism: A handbook (pp. 12-32). London, England: Taylor \& Francis.

Roggenbuck, J. W., Williams, D. R., \& Watson, A. E. (1993). Defining acceptable conditions in wilderness. Environmental Management, 17, 187-197.

Rom, F. (2010, March). Exploring relationships between environmental beliefs and landscape preferences: A comparison between visitors to protected areas in Austria and the United States. In: The Georg Wright Society, Book of Abstracts, The Georg Wright Society Conference on Parks, Protected Areas \& Cultural Sites (S125). New Orleans, LA.

Roy, B. (1990). The outranking approach and foundations of the ELECTRE methods. In B. Costa \& A. Carlos (Eds.), Readings in multiple criteria decision aid (pp. 156-183). Berlin, Germany: Springer-Verlag.

Rutherford, I. (1998). Pieces of a greater picture. In B. Moldan, S. Bilharz, \& R. Matravers (Eds.), Sustainability indicators: Report on the project on indicators of sustainable tourism (pp. 149-156). Chichester, England: Wiley \& Sons.

Ryan, G. (1999). Measuring the typicality of text: Using multiple coders for more than just reliability and validity checks. Human Organization, 58(3), 313-322.

Ryan, G. W., and H. R. Bernard, H. R. (2000). Data management and analysis methods. In N. Denzin \& Y. Lincoln (Eds.), Handbook of qualitative research, $2 d$ ed.(pp. 769-802). Thousand Oaks, CA: Sage.

Sample, V. A., Price, W., Donnay, J. S., \& Mater, C. A. (2007). National forest certification study: An evaluation of the applicability of Forest Stewardship Council (FSC) and Sustainable Forest Initiative (SFI) standards on five national forests. Washington, DC: Pinchot Institute for Conservation.

Saremba, J., \& Gill, A. (1991). Value conflicts in mountain park settings. Annals of Tourism Research, 18, 455-472.

Schauman, S. (1988). Countryside scenic assessment: Tools and an application. Landscape and Urban Planning, 15, 227-239. 
Schiemer, F., Baumgartner, C., \& Tockner, K. (1999). Restoration of floodplain rivers: The 'Danube Resoration Project.' Regulated Rivers Research and Management, 15(1-3), 231244.

Schroeder, H. W., Dwyer, J. F., Louviere, J. J., \& Anderson, D. H. (1990). Monetary and nonmonetary trade-offs of urban forest site attributes in a legit model of recreation choice (U.S. Forest Service General Technical Report RM-197, pp. 41-51). Washington, DC: U.S. Department of Agriculture, Forest Service.

Schuh, B., \& Oraze, H. (2005). International benchmarking of Styrian government economic support measures compared with those of four European regions (Provincial Government of Styria, Project Report FA 14A). Vienna, Austria: Department for Economic Affairs.

Shelby, B., \& Harris, R. (1985). Comparing methods for determining visitor evaluation of ecological impacts: Site visits, photographs and written descriptions. Journal of Leisure Research, 17, 57-67.

Shelby, B., \& Heberlein, T. A. (1984). A conceptual framework for carrying capacity determination. Leisure Sciences, 6, 433-451.

Shelby, B., \& Heberlein, T. A. (1986). Carrying capacity in recreational settings. Corvallis: Oregon State University Press.

Shelby, B., \& Vaske, J. J. (1991). Using normative data to develop evaluative standards for resource management: A comment on three recent papers. Journal of Leisure Research, $23,173-187$.

Shelby, B., Vaske, J. J., \& Heberlein, T. A. (1989). Comparative analysis of crowding in multiple locations: Results from 15 years of research. Leisure Sciences, 11, 269-291.

Shuttleworth, S. (1980). The use of photographs as environmental presentation medium in landscape studies. Journal of Environmental Management, 11, 61-76.

Sievänen, T., Arnberger, A., Dehez, J., \& Jensen, F. S. (2009). Monitoring of forest recreation demand. In S. Bell, M. Simpson, L. Tyrväinen, T. Sievänen, \& U. Pröbstl (Eds.), European forest recreation and tourism: A handbook (pp. 105-133). London, England: Taylor and Francis.

Simon, H. A. (1982). Models of bounded rationality. Cambridge, MA: MIT Press.

Stankey, G. H. (1980). A comparison of carrying capacity perceptions among visitors to two wildernesses (Research Paper INT-242). Ogden, UT: USDA FS Intermountain Forest and Range Experiment Station. 
Stankey, G. H., Cole, D. N., Lucas, R. C., Peterson, M. E., \& Frissell, S. S. (1985). The limits of acceptable change (LAC) system for wilderness planning (U.S. Forest Service General Technical Report INT-176). Ogden, UT: U.S. Department of Agriculture, Forest Service, Intermountain Forest and Range Experiment Station.

Steen, H. K. (1976). The United States Forest Service, A history. Seattle, WA: University of Washington Press.

Sterl, P., Wagner, S., \& Arnberger, A. (2004). Social carrying capacity of canoeists in Austria's Danube Floodplains National Park. Vienna, Austria: Institute for Landscape Development, Recreation and Conservation Planning, BOKU-University of Natural Resources and Applied Life Sciences.

Steiner, W., \& Parz-Gollner, R. (2003). Actual numbers and effects of the recreational disturbance on the distribution and behavior of greylag geese (Anser anser) in the Neusiedler See-Seewinkel National Park area. Journal for Nature Conservation, 11, 324330.

Stewart, W. (1989). Fixed itinerary systems in back-country management. Journal of Environmental Management, 29, 163-171.

Storch, I., \& Leidenberger, C. (2003) Tourism, mountain huts and distribution of corvids in the Bavarian Alps, Germany. Wildlife Biology, 9, 301-308.

Synge, H. (2004). Visitor management in Hohe Tauern National Park, Austria. In H. Synge (Ed.), European models of good practice in protected areas (pp. 23-28). Gland, Switzerland: IUCN.

Taczanowska, K., Muhar, A., \& Arnberger, A. (2006). Exploring spatial behavior of individual visitors as background for agent-based simulation. In D. Siegrist, C. Silvas, M. Hunsiker, $\&$ S. Iten (Eds.), Proceedings from the ICMMVF '06: Exploring the nature of management. The 3rd international conference on monitoring and management of visitor flows in recreational and protected areas. Rapperswil, Switzerland.

Tarrant, M. A., Cordell, H. K., \& Kibler, T. L. (1997). Measuring perceived crowding for highdensity river recreation: The effects of situational conditions and personal factors. Leisure Sciences, 19, 58-112.

Taylor, R., \& Judd, L. (1989). Delphi method applied to tourism. In S. Witt \& L. Mouthina (Eds.), Tourism marketing and management handbook (pp. 95-98). Englewood Cliffs, NJ: Prentice Hall.

Thiel, D., Jenni-Eiermann, S., Braunisch, V., Palme, R., \& Jenni, L. (2008). Ski tourism affects habitat use and evokes a physiological stress response in capercaillie Tetrao urogallus: A new methodological approach. Journal of Applied Ecology, 45, 845-53. 
United Nations Educational, Scientific and Cultural Organization (UNESCO). (1996). The Seville strategy for the world network of biosphere reserves.

US Congress. Multiple-Use and Sustained Yield Act of 1960, Pub. L. 86-517, 86th Congress (1960).

US Department of Agriculture, Forest Service. (1996). Outfitter/Guides needs assessment for Coconino National Forest (U.S. Forest Service Proposal Draft). Fort Collins, CO: U.S. Department of Agriculture, Forest Service, Rocky Mountain Forest and Range Experiment Station.

US Department of Agriculture, Forest Service. (2004). National visitor use monitoring (NVUM) National Program results: January 2000 through September 2003.

US Department of Agriculture, Forest Service. (2008a). Final directives for outfitting and guiding special use permits and insurance requirements for Forest Service special use permits (U.S. Forest Service FSH 2709.11, Ch. 40 + 30, FSM 2713, Federal Register, pp. 53823-53845).

US Department of Agriculture, Forest Service. (2008b, July). Recreation for the next century. Meeting notes.

US Environmental Protection Agency (EPA). Clean Air Act of 1963, Pub. L. No. 88-206, 77 Stat. 392, (1963).

US Forest Service. (2008). Mission, motto, vision, and guiding principles.

Van Wagtendonk, J., \& Coho, P. (1986). Trailhead quotas: Rationing use to keep wilderness wild. Journal of Forests, 84, 22-24.

Vaske, J. J., Donnelly, M. P., \& Petruzzi, J. P. (1996). Country of origin, encounter norms and crowding in front-country settings. Leisure Sciences, 18, 161-165.

Von Ruschkowski, E., Valdeig, S., Jakob, R., \& Homann, S. (2008, October). Designing a visitor monitoring concept for Harz National Park in Germany. In A. Raschi \& S. Trampetti (Eds.), Proceedings from management for protection and sustainable development: The 4th international conference on monitoring and management of visitor flows in recreational and protected areas. Montecatini Terme, Italy.

Wager, J. (1964). The carrying capacity of wildlands for recreation (Forest Service Monograph 2). Washington, DC: Society of American Foresters.

Wagner, S., Sterl, P., \& Arnberger, A. (2003, January). Disturbance of avifauna caused by water sports activities in Austria's Danube Floodplains National Park. In A. Arnberger, C. Brandenburg, \& A. Muhar (Eds.), Proceedings from '02 conference: Monitoring and 
management of visitor flows in recreational protected area (pp. 460-466). Jena, Germany: Urban \& Fisher Verlag.

Walters, C., Korman, J., Stevens, L. E., \& Gold, B. (2000). Ecosystem modeling for evaluation of adaptive management policies in the Grand Canyon. Conservation Ecology, 4(2), 1.

Wang, B., \& Manning, R. E. (1999). Computer simulation modeling for recreation management: A study on carriage road use in Acadia National Park, Maine, USA. Environmental Management, 23, 193-203.

Wasser, S. K., Bevis, K., King, G., \& Hanson, E. (1997). Noninvasive physiological measures of disturbance in the northern spotted owl. Conservation Biology, 11(4), 1019-1022.

Watson, A. E., Cole, D. N., Turner, D. L., \& Reynolds, P. S. (2000). Wilderness recreation use estimation: A handbook of methods (U.S. Forest Service General Technical Report RMRS-GTR-56). Ogden, UT: U.S. Department of Agriculture, Forest Service, Rocky Mountain Research Station.

Watson, A. E., Cronn, R., \& Christensen, N. A. (1998). Monitoring inter-group encounters in wilderness (U.S. Forest Service Research Paper RMRS-RP-14). Ogden, UT: U.S. Department of Agriculture, Forest Service, Rocky Mountain Research Station.

Weeks Act, Pub. L. No. 110-343, 36 Stat. 961 (1911).

Weiermar, K., Peters, M., \& Frehse, J. (2008). Success factors for public private partnership: Cases in Alpine tourism development [Special issue]. Journal of Services Research, 8.

Wendt, R. (2006). Quantitatives besuchermonitoring im Nationalpark Hochharz als argumentations-und entscheidungshilfe [Quantitative visitor monitoring in National Park Harz as a decision-making support tool]. In T. Reech \& G. Ströhleim (Eds.), Zu besuch in Deutschlands mitte: Natur-kultur-turismus [Visiting central Germany: Nature-CultureTourism] (pp. 59-82). Göttingen, Germany: University.

Williams, D. R., Roggenbuck, J. W., \& Bange, S. P. (1991). The effect of norm-encounter compatibility on crowding perceptions, experience, and behavior in river recreation settings. Journal of Leisure Research, 23, 154-172.

Wipf, S., Rixen, C., Fischer, M., Schmid, B., \& Stoeckli, V. (2005). Effects of ski piste preparation on alpine vegetation. Journal of Applied Ecology, 42, 306-316.

Wirth, V., Sterl, P., \& Pröbstl, U. (2006). The tourists' view on protected areas. In D. Siegrist, C. Silvas, M. Hunsiker, \& S. Iten (Eds.), Proceedings from the ICMMVF '06: Exploring the nature of management. The 3 rd international conference on monitoring and management of visitor flows in recreational and protected areas. Rapperswil, Switzerland. 
Yong, Y., Keng, K., \& Leng, T. (1988). A Delphi forecast for the Singapore tourism industry: Future scenario and marketing implications. International Marketing Review, 6(3), 35-46. 


\section{Appendix A}

\section{Pilot Research Instrument for USFS Special Use Permit (SUP) Study}

1 \} ::: Who handles the distribution of recreation special use permits for this forest? (Names/titles of players)

2 \}<::: What activities or events are managed under the SUP process?

3 \} ::: How many special use permits does your forest manage per year?

3a \}:: Has that number changed in the past few years, and why?

4 \}<::: Does your forest use any other processes, such as commercial use agreements, concessions or cooperative agreements, to manage various uses of the forest?

4a \}:: If yes, what determines which process is used?

5 \} $<::$ : Are there any limits on the numbers of special use permits issued?

5a \}:: If yes, what types of uses are limited, and which ones are unlimited?

6 \}<::: Are there limits on the numbers of users allowed under any of your special use permits (e.g. a limited number of rafters per day)?

6a \}:: If yes, what types of special use permits include such limits?

7 \}<::: Is the demand for use greater than the supply available through special use permits (i. e. is there unmet demand)?

8 \}<::: Have requests for special use permits been denied in your forest?

8a \}:: If yes, how often, which groups, and why?

9 \}<::: Are you experiencing any problems administering your special use permit program?

10 \}<::: Do you believe that SUPs are distributed fairly on your forest?

11 \}<::: How well do you believe your forest's existing SUP process meets the needs of your users (and potential users)?

12 \}<::: Are you aware of the changes in the SUP process that were outlined in the latest Federal Register?

12a \}:: If yes, how do you feel about the proposed changes? 


\section{Appendix B}

\section{Pilot Research Instrument Incorporating Austrian Managers into Study}

1 \}<::: What is your job title?

1a \}-:: How would you summarize your daily responsibilities?

1b \}-:: How would you summarize your long term responsibilities/goals?

2 \}<::: Is there enough recreational use in your area to cause concern of degrading natural resources, i.e. carrying capacity isssues?

2a \}-::What are your main concerns/issues?

2b \}-:: In what ways do you manage/control this use?

3 \}<::: Is there enough recreational use to cause conflicts between users, i.e. crowding?

4 \}<::: What is your best definition of visitor management (how does the term apply to your work in your own words)? 


\section{Appendix C}

\section{Delphi Research Instrument: First Round}

(Translated by Eick von Ruschkowski)

1 \}<::: Please describe the natural resources of your area (river, park, or forest).

1a \}:: What environmental impacts does recreational use have upon these resources?

[Bitte beschreiben Sie die Naturausstattung Ihres Schutzgebietes (insbesondere die Eigenschaften, die eine Bedeutung für die Erholungsnutzung haben).

a \}:: Welche Umweltauswirkungen werden durch die Erholungsnutzung in diesem Gebiet hervorgerufen?]

2 \}<::: What is the economic value of this river, park, or forest to the community (community is self-defined)?

[Wie hoch ist der ökonomische Stellenwert (regionale Wertschöpfung) des Schutzgebietes / Flusses / Waldes?]

3 \}<::: What are the primary recreation use activities in your area?

[Welche Formen der Erholungsnutzung finden vorrangig in dem Schutzgebiet / Fluss / Wald statt?]

4 \}<::: How much recreational use is occurring on the river, park, forest?

4a \}:: In what way(s) was the amount or estimation obtained/measured?

4b \}:: How much use can be expected in the future?

4c \}:: What is the prediction based upon (how was it calculated/estimated)?

[In welcher Intensität finden die Nutzungen statt?

a \}:: In welcher Form wird die Intensität der Nutzungen ermittelt oder geschätzt?

b \}:: Wie wird sich das Ausmaß der Nutzungen zukünftig verändern?

c \}:: Auf welcher Grundlage wird diese Annahme getroffen

(Berechnungen / Schätzungen)?]

5 \}<::: How is recreational use managed, if at all, in your area?

5a \}:: What are users' opinions about management?

[In welcher Form wird die Erholungsnutzung im Gebiet geregelt bzw. gesteuert, wenn überhaupt (Besucherlenkung und-management)?

a \}:: Wie reagieren die Nutzer auf entsprechende Regelungen?]

6 \}<::: What are users seeking in a river, park, forest experience in your area?

[Welche Form des (Natur-)Erlebens wünschen sich die Nutzer in diesem Gebiet?]

7 \}::: Is there conflict among users on the river? (If not, please proceed to Q8) 
7a $\}::$ Please describe the nature of the conflict(s) and the demographics of the parties involved.

7b \}:: Do any conflicts in the river, park, or forest cause the displacement of users?

[Bestehen auf diesem Fluss Konflikte zwischen einzelnen Nutzergruppen (wenn nein, dann mit Frage 8 weiter)?

a \}:: Bitte beschreiben Sie die Ursachen für die Konflikte und die demographischen Eigenschaften der involvierten Nutzergruppen

b \}:: Führen diese Konflikte dazu, dass einzelne Nutzer dieses Gebiet meiden?]

8 \}<::: Is there a specific niche that your area fills compared to other parks/rivers/forests?

[Nimmt dieses Gebiet im Vergleich mit anderen Schutzgebieten / Flüssen /

Wäldern eine Sonderstellung hinsichtlich der Erholungsnutzungen ein

(Alleinstellungsmerkmal, Exklusivität, Spartenangebote)?]

9 \}<::: Please describe the use regulation policy for the river, park, or forest.

9a \}:: What are your main objectives or goals regarding use regulation or carrying capacity?

[Bitte beschreiben Sie die einschlägigen gesetzlichen Regelungen, die für das

Management der Erholungsnutzung in diesem Gebiet / Fluss / Wald von

Bedeutung sind.

a \}:: Welche sind die vorrangigen Ziele in Bezug auf Besucherlenkung,

Nutzungsregulierung und Tragfähigkeit?]

10 \}<::: What management techniques/frameworks are available and how well do they work?

10a \}:: How well would you rate your knowledge of available frameworks compared to others? (well under average, under average, average, above average, well above average)

[Welche Rahmenkonzepte oder Steuerungsmöglichkeiten sind für das Besuchermanagement verfügbar, werden sie angewendet und wie gut funktionieren sie?

a \}:: Wie schätzen Sie Ihre eigene Erfahrung über derartige

Rahmenkonzepte und Steuerungsmöglichkeiten im Vergleich zu anderen

Personen ein, die in ihrem Feld tätig sind (weit unterdurchschnittlich, unterdurchschnittlich, gleich, überdurchschnittlich, weit überdurchschnittlich)?]

11 \}<::: How do you learn about existing management information and research (where do you get your information)?

[Wie gelangen Sie an Informationen über Praxis und Forschung im Bereich des Besuchermanagements?] 


\section{Appendix D}

\section{Delphi Research Instrument: Second Round}

(Translated by Franziska Rom)

I. Visitor Impacts on Natural Resources

[I. Einfluss der Besuchernutzung auf die natürlichen Ressourcen]

1 \}<::: We want to understand your opinions about potential impacts of social use on the natural resources of your area. For each of the statements below, please indicate your level of agreement or disagreement by placing an " $\mathrm{x}$ " in the appropriate box.

[Uns interessiert Ihre Meinung über potentielle Auswirkungen der sozialen Nutzungen auf die natürlichen Ressourcen. Bitte kreuzen Sie mit einem „x“ im jeweiligen Feld Ihr Übereinstimmungslevel für jede der folgenden Aussagen an.]

"Recreational Visitor Use causes a consistent and severe negative impact to the natural resources of the area."

[Erholungsnutzung verursacht einen beständigen und starken negativen Einfluss auf die natürlichen Ressourcen des Gebietes.]

"Recreational Visitor Use causes some negative impacts on the natural integrity of the area."

[ Erholungsnutzung verursacht einige negative Einflüsse auf die Unversehrtheit der Natur.]

"There are certain hot-spots or areas that suffer to some degree from visitor use or overuse."

[Es gibt bestimmte hot spots oder Gebiete, die unter den Besuchern oder Übernutzung leiden.]

"Recreation Visitor Use is suspected of having negative impacts, but this has not estimated or measured as of yet."

[Es wird angenommen, dass

Erholungsnutzung einen negativen Einfluss hat, jedoch wurde dies bis jetzt noch nicht bewertet bzw. gemessen.]

"Most negative impacts from recreational visitor use are due to visitors not following regulations."

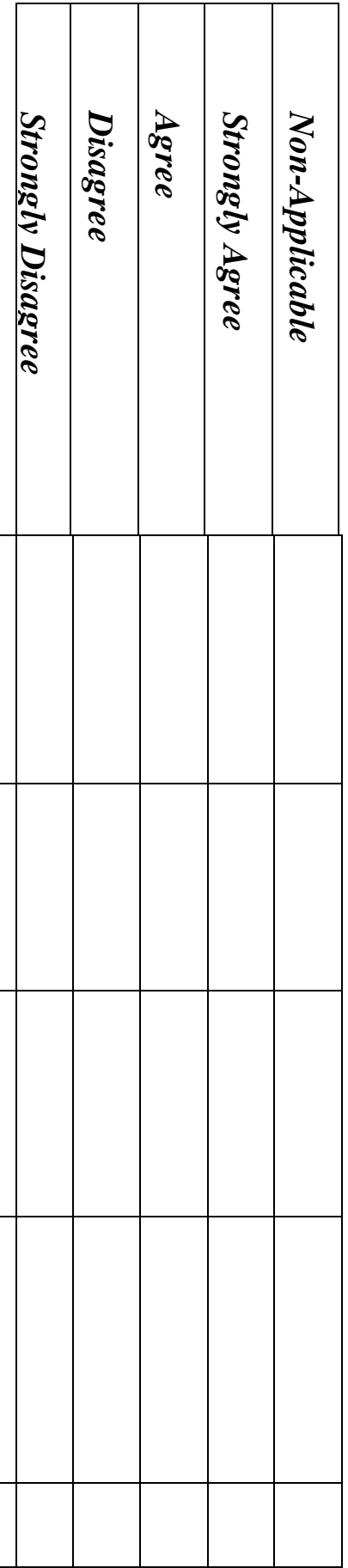




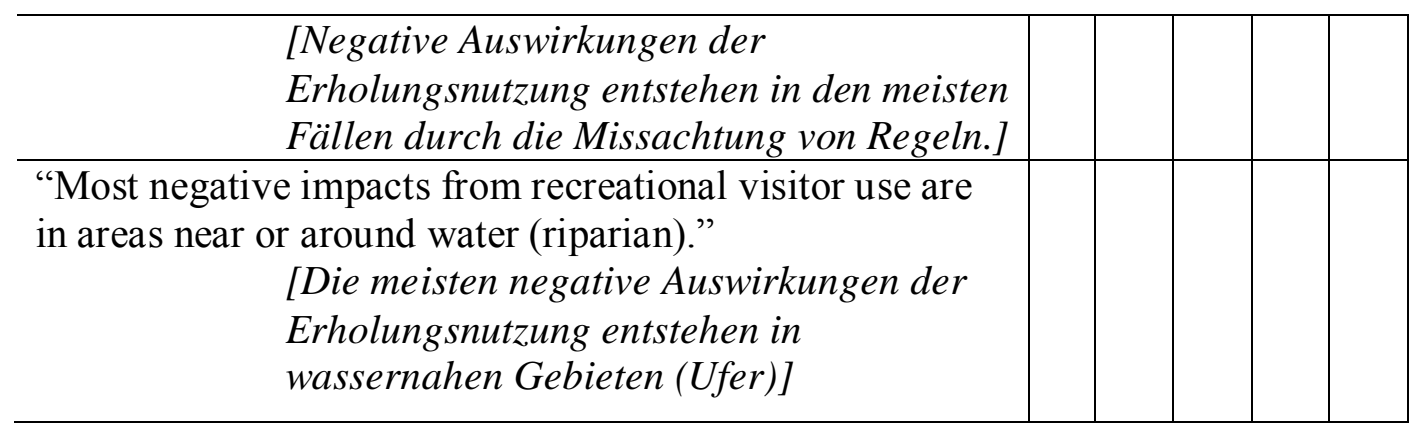

2 \}<::: We want to understand your opinions about the effect of potential impacts of social use on the natural resources of your area. The table below lists the potential negative impacts on natural resources caused by visitor use that were most frequently addressed by managers during the first round of questions. Please indicate any of the following conditions occurring in your area by placing an " $x$ " in each adjacent box. Please rank your top 3 (1=greatest impact) If any item does not apply, please leave it blank.

[Uns interessiert Ihre Meinung bezüglich der Einflüsse potenzieller Auswirkungen von sozialen Nutzungen auf die natürlichen Ressourcen in Ihrem Gebiet. Die folgende Tabelle enthält mögliche negative Auswirkungen von Besuchernutzungen, die in der ersten Fragerunde am häufigsten von Managern genannt wurden. Bitte geben Sie für die folgenden Bedingungen mit einem , x“ im dazugehörigen Feld jene an, die in Ihrem Gebiet vorkommen. Bitte reihen Sie Ihre Top 3 (1= größte Auswirkung). Lassen Sie jene Auswirkungen frei, die Sie nicht betreffen.]

\begin{tabular}{c|c|c|}
\hline $\begin{array}{c}\text { Compromised water quality } \\
\text { [Beeinträchtigung der Wasserqualität] }\end{array}$ & Place X & Rank \\
\hline $\begin{array}{c}\text { Invasive species } \\
\text { [Neophyten und Neozoen] }\end{array}$ & \\
\hline $\begin{array}{c}\text { Pollution (waste or noise) } \\
\text { [Immissionen (Schmutz oder Lärm)] }\end{array}$ & \\
\hline $\begin{array}{c}\text { Riparian habitat degradation } \\
\text { [Verschlechterung der Uferhabitate] }\end{array}$ & \\
\hline $\begin{array}{c}\text { Vegetation [Vegetation] } \\
\text { [Veränderungen von Habitaten / Verhalten der } \\
\text { Wildtiere] }\end{array}$ & \\
& \\
\hline
\end{tabular}

3 \}<::: We want to understand your opinions about which recreation activities cause the most negative impacts on the natural resources of your area. The table below contains the activities most frequently reported as causing negative impacts to the 
areas' natural resources. Please indicate your perception of the negative impacts of these activities on your area by typing an " $x$ " in the box next to each activity that has a negative impact, and then ranking your top 3 in order of $1=$ the activity causing the heaviest negative impacts.

[Welche Erholungsnutzung verursacht, Ihrer Meinung nach, die stärksten negativen Auswirkungen auf die natürlichen Ressourcen Ihres Gebietes?

Die folgende Tabelle enthält die in der ersten Fragerunde am häufigsten genannten Aktivitäten mit negativem Einfluss auf die natürlichen Ressourcen. Bitte kennzeichnen Sie jene Aktivitäten, die Ihrer Meinung nach einen negativen Einfluss auf die natürlichen Ressourcen in Ihrem Gebiet haben, mit einem „x“ im dazugehörigen Feld. Bitte reihen Sie Ihre Top 3 (1= Aktivität mit stärkster Auswirkung). Lassen Sie jene Aktivitäten frei, die Sie nicht betreffen.]

\begin{tabular}{c|c|c}
\hline Boating [Bootfahren] & Place X & Rank \\
\hline Camping [Camping] & & \\
\hline $\begin{array}{c}\text { Commercial/agricultural use } \\
\text { [Kommerzielle/landwirtschaftliche Nutzung] }\end{array}$ & & \\
\hline $\begin{array}{c}\text { Hiking/off-trail use } \\
\text { [Wandern/Verlassen der Wanderwege] }\end{array}$ & & \\
\hline $\begin{array}{c}\text { Motor vehicle use } \\
\text { [Nutzung motorisierter Geräte] }\end{array}$ & & \\
\hline $\begin{array}{c}\text { Other recreational-related use } \\
\text { [Weitere erholungsähnliche Nutzung] }\end{array}$ & & \\
\hline
\end{tabular}

4 \}<::: Please list any activity-specific restrictions or regulations in your area that were a result of the conditions listed in Question 2a.

[Bitte listen Sie jene Regulierungen für Aktivitäten in Ihrem Gebiet, die aus den in Frage 2 a angeführten Bedingungen resultieren.]

5 \}<::: Please list and explain any visitor use or natural resource condition monitoring taking place in your area.

[Bitte listen Sie jedes Besuchermonitoring bzw. Monitoring der natülichen Ressourcen, das in Ihrem Gebiet stattfindet.]

II. User Vs. User Conflicts

[II. Besucher vs. Besucher Konflikte]

6 \}<::: The types of user vs. user or social conflicts reported most frequently in the first round are listed in the table below. Please type an " $\mathrm{x}$ " in the box beside each type of social conflict that occurs in your area. Please rank your top 3 (1=greatest impact) If any item does not apply, please leave it blank. 
[In der folgenden Tabelle finden Sie die Arten von Besucher vs. Besucher bzw. soziale Konflikte, die in der ersten Fragerunde am häufigsten genannt wurden. Bitte kennzeichnen Sie jene Konflikte, die in Ihrem Gebiet vorkommen mit einem " $x$ ” im dazugehörigen Feld. Bitte geben Sie Ihre Top 3 (1=stärkste Auswirkung) an. Lassen Sie jene Konflikte frei, die Sie nicht betreffen.]

\begin{tabular}{|c|c|c|}
\hline & $\begin{array}{l}\text { Place } \\
\text { X }\end{array}$ & Rank \\
\hline $\begin{array}{l}\text { Crowding conflicts on holidays/weekends } \\
\qquad \begin{array}{l}\text { [Besucherandrang an stark frequentierten Tagen } \\
\text { /Feiertagen] }\end{array}\end{array}$ & & \\
\hline $\begin{array}{l}\text { Motorized vs. non-motorized users } \\
\qquad \text { [Motorisierte vs. nicht motorisierte Besucher] }\end{array}$ & & \\
\hline $\begin{array}{l}\text { Nature-viewers vs. recreation users } \\
\qquad \text { [Naturbeobachter vs. Erholungssuchende] }\end{array}$ & & \\
\hline $\begin{array}{l}\text { Private vs. commercial users } \\
\qquad \text { [Private vs. kommerzielle Nutzer] }\end{array}$ & & \\
\hline $\begin{array}{l}\text { Riverside vs. river users } \\
\qquad \begin{array}{l}\text { [Besucher der Ufergegend vs. Nutzer des Flusses } \\
\text { selbst] }\end{array}\end{array}$ & & \\
\hline $\begin{array}{l}\text { Sanitation issues (current users vs. past users) } \\
\text { [Sanitäre Themen (derzeitige vs. vorangegangene } \\
\text { Nutzer)] }\end{array}$ & & \\
\hline
\end{tabular}

7 \}<::: Please explain how you manage crowding or conflicts between users in your area. [Bitte geben Sie an, wie Sie Besucherandrang oder weitere Konflikte zwischen den Nutzern Ihres Gebietes regeln.]

\section{Management Practices and Methods}

\section{[III. Management Praktiken und Methoden]}

8 \}<::: We want to understand whether the management of your area is influenced by international, national, local or area specific policies. Please rank your top 4 ( $1=$ most influential) If any item does not apply, please leave it blank.

[Wir sind daran interessiert, ob das Management Ihres Gebietes durch internationale, nationale, lokale oder gebietsbezogene Maßnahmen beeinflusst wird. Bitte geben Sie Ihre Top 4 Reihung an $(1=$ am einflussreichsten). Lassen Sie jene Punkte frei, die Sie nicht betreffen..]

\begin{tabular}{l|l|l}
\hline & \multicolumn{1}{|c|}{ Rank } & \\
\hline International & & \\
\hline National & & \\
\hline Local & & \\
\hline Area Specific & & \\
\hline
\end{tabular}


9 \}<::: Next, please type the name of at least one policy, act, or framework you follow from each level in the space next to the ranking.

[Als nächstes, bitten wir Sie, für jede Ebene den Namen von mindestens einer Maßnahme, Rahmenbedingung, Strategie etc. die Sie umsetzen, anzugeben.]

10 \} ::: We want to understand the spectrum of management actions, frameworks and policies that are used in your area. Please rank your top 3 (1=most influential) If any item does not apply, please leave it blank.

[Wir sind am Umfang der Management Maßnahmen, Rahmenbedingungen und Strategien in Ihrem Gebiet interessiert. Bitte kennzeichnen Sie jene Maßnahmen und Regulierungen die in Ihrem Gebiet vorkommen mit einem " $x$ ” im dazugehörigen Feld. Bitte geben Sie Ihre Top 3 an $(1=a m$ einflussreichsten). Lassen Sie jene Punkte frei, die Sie nicht betreffen.]

11 \}<::: Please list any other management techniques or frameworks that have been found to be effective that are not listed above.

[Bitte nennen Sie all jene effektiven Management Maßnahmen oder Regelungen, die in der vorangegangenen Liste nicht angeführt wurden].

12 \} ::: We want to understand your opinion of the most important management considerations that may be contained in an area's plans or objectives. Multiple areas are very likely working towards the same objectives from completely different angles. For example, in the book Studies in Outdoor Recreation, Robert Manning separates the intentions behind management objectives into 3 types of 'considerations.' They are:

$\underline{\text { Natural Considerations }}=$ "the biophysical characteristics of the natural resource base that help determine the degree of change from recreational use." $\underline{\text { Social Considerations }}=$ "the needs and wants of visitors [used in] determining appropriate outdoor recreation opportunities."

$\underline{\text { Management Considerations }}=$ "legal directives, agency mission statements, and other policy-related guidelines that may suggest appropriate management objectives and related indicators and standards of quality" (Manning, 1999).

Using the definitions above, please explain the significance of the natural, social and management considerations in your own words.

[Uns interessiert Ihre Meinung über die wichtigsten Überlegungen des Managements, die in einem Gebietsplan oder in den Leitzielen hineinfließen. Bitte reihen Sie die 3 Arten an Überlegungen entsprechend der Anwendung in Ihrem Management als ,, wenig wichtig“, ,wichtig“ oder ,, am wichtigsten “. Nach der Reihung, nennen Sie uns bitte für jede Kategorie mindestens eine Idee oder Zielsetzung, die in Ihrem Management Plan umgesetzt wird.

ÖKOLOGISCHE ÜBERLEGUNGEN: SOZIALE ÜBERLEGUNGEN: MANAGEMENT ÜBERLEGUNGEN:] 
13 \}<::: We want to understand how important you feel it is to communicate and collaborate with other natural resource managers. For each of the statements below, please indicate your level of agreement or disagreement by placing an " $\mathrm{x}$ " in the appropriate box.

[Uns interessiert, wie wichtig für Sie die Kommunikation und Zusammenarbeit mit anderen Ressourcen Managern ist. Bitte geben Sie Ihr Übereinstimmungslevel für die folgenden Aussagen mittels eines " $x$ " im entsprechenden Feld an.]

Communicating and collaborating with other natural resource managers would not be worth the time and effort

[Die Kommunikation und Zusammenarbeit mit anderen Ressourcen Managern ist den Zeitaufwand und die Mühe nicht wert.]

A lot can be learned by collaborating with other managers on a National level

[Auf nationalem Level kann viel durch die Zusammenarbeit mit anderen Managern gelernt werden]

A lot can be learned by collaborating with other managers from different countries

[Durch die Zusammenarbeit mit Managern aus anderen Ländern kann viel gelernt werden.]

Communicating and collaborating with other natural resource managers would result in a positive net gain for our area [Die Kommunikation und Zusammenarbeit mit anderen Ressourcen Managern würde in einem positiven Nettogewinn für das Gebiet resultieren.] 


\section{Appendix E}

\section{English Summary Preceding Second Round Delphi Survey Instrument}

\section{Summary of the Previous Round of Delphi Questions}

The following content is the condensed results from the previous round of questions in this Delphi study. Only the observations and inferences relevant to the new questions are provided below, as an informative precursor to start everyone off on the same page.

The outcome categories used in this study were extracted from a coding framework derived from all of the open-ended answers to the initial Delphi questionnaire. If certain answers were given repeatedly, they were used as the categories for the coding framework for that question. The questions that yielded a broader range of responses were conditionally categorized into common themes or topics. When necessary, for purposes of normalization, existing published categories formed from studies conducted on issues of recreation visitor management and social carrying capacity concerns were adapted from Manning's Studies in Outdoor Recreation, Search and Research for Satisfaction (1999) and applied to the categorization of this study.

The Round One questions focused on the current visitor situations and issues, Round Two will focus more on the methods used to achieve ideal conditions, along with other topics found to be widely relevant after analyzing the answers from the First Round.

\section{Visitor Use Impacts on Natural Resources}

Overall, it appears from the mean results that the areas in the Pacific Northwest U.S. see more visitors, and therefore deal with more visitor-related and heavier environmental degradation issues than the majority of the Austrian areas. However, the types of visitor use-related environmental damage were reported similarly from both sides. The top issues for many areas were vegetation loss, wildlife habitat/behavior modification, and riparian habitat degradation. All U.S. managers reported soil compaction/erosion, and almost all Austrian managers specified bird or wildlife habitat disturbance.

The activities known or expected of causing these damages varied. The most commonly reported damage-causing activities were hiking (over 2/3 of both U.S. and Austrian areas) and boating (over half of U.S., 2/7 Aus.). The other activities of concern from the U.S. managers were: motor vehicle use, and camping. The Austrians reported experiencing issues with fishing and agricultural use as well.

\section{User Vs. User Conflicts}

Out of the areas that reported experiencing conflict (6 of 9 Americans, 3 of 9 Austrians), the two types of conflicts reported from both countries were riverside users vs. river users and crowding issues during high traffic/holiday times. Other issues reported by Austrian managers were: nature viewers vs. recreation users, hikers/walkers vs. bikers. The other issues described by 
American managers were: land owners vs. recreation users, private use vs. commercial use, motorized vs. non-motorized users, and sanitation issues/user vs. past user issues.

\section{Management Practices/Methods}

Overlapping results were given in the last survey for the questions asking for a description of "ways recreation use impacts are managed" and "Use regulation techniques," therefore these various elements were categorized together and reclassified as "management techniques." The categories derived from these questions are generalized actions under which all of the specific examples can be classified. These actions, such as discouraging the use of environmentally sensitive areas, and educating visitors in advance,' are addressed in question 6 of this round.

\section{Thank you again for your participation!}




\section{Appendix F}

\section{German Summary Preceding Second Round Delphi Survey Instrument}

\section{Zusammenfassung der letzten Fragerunde der Delphi Fragen}

Die Antwortkategorien, die in dieser Studie verwendet werden, wurden einem Kodierungssystem entnommen, welches sich aus den offenen Antworten des ersten Delphi Fragebogens ableitete. Wurden bestimmte Antworten zu einer Frage wiederholt gegeben, wurden diese als Kategorien für das Kodierungssystem dieser Frage verwendet. Jene Fragen, die zu einem breiteren Spektrum an Antworten führten, wurden in gemeinsamen Themenkategorien zusammengefasst. Um die Vollständigkeit der Antwortkategorien zu garantieren, wurden, falls notwendig, bestehende und veröffentlichte Kategorien, von Studien zum Erholungsbesuchermanagement und zur sozialen Tragfähigkeit (social carrying capacity) von Robert Manning's Studies in Outdoor Recreation, Search and Research for Satisfaction (1999), angepasst und auf die Kategorisierung dieser Studie angewandt.

Die erste Fragerunde fokussierte auf die jetzige Besuchersituationen und -Angelegenheiten. Die zweite Fragerunde wird sich auf die notwendigen Managementmethoden für ideale Bedingungen konzentrieren. Hinzu kommen noch weitere Themen, die sich im Zuge der Auswertung der ersten Fragerunde als wesentlich herauskristallisierten.

\section{Einfluss der Besuchernutzung auf die natürlichen Ressourcen}

Insgesamt ergibt sich aus den Ergebnissen, dass in den Gebieten des Pazifischen Nord Westen der USA mehr Besucher gezählt werden, und daher auch besucherbezogene Themen und Themen wie die Degradation der Natur häufiger behandelt werden als in der Mehrheit der österreichischen Gebiete. Allerdings berichteten beide Seiten von ähnlichen Arten besucherverursachter Umweltschäden. Die Hauptthemen vieler Gebiete waren der Verlust an Vegetation, Lebensraum der Wildtiere / Verhaltensveränderungen, und Verlust an Uferlebensräumen. Alle U.S. Manager berichteten von Bodenverdichtung und -Erosion und beinahe alle österreichischen Manager nannten die Beeinträchtigung der Vogel- und Wildtierlebensräume als wesentliche Folge der Besuchernutzung.

Die bekannten und vermuteten Aktivitäten, welche die Schäden verursachen, variierten. Als die am meisten genannten schadensverursachenden Aktivitäten wurden das Wandern (über 2/3 sowohl in amerikanischen und österreichischen Gebieten) und das Bootfahren (über die Hälfte in den USA und 2/7 in Österreich) genannt. Weitere Aktivitäten, die die U.S. Gebiete betreffen sind: die Verwendung von Motorfahrzeugen und Camping. Die Österreicher berichteten von Problemen mit der Fischerei und der Landwirtschaft.

\section{Besucher vs. Besucher Konflikte}

In den Gebieten, in welchen Besucherkonflikte gemeldet wurden (6 von 9 in Nordamerika, 3 von 9 in Österreich), wurde in beiden Ländern von zwei Arten von Konflikten berichtet. Diese sind Besucher der Ufergegend vs. Nutzer des Flusses selbst und der Besucherandrang während stark 
frequentierten Tagen / Feiertagen. Weitere Konflikte die von Österreichischen Managern genannt wurden sind: Naturbeobachter vs. Erholungssuchende, Wanderer/Walker vs. Radfahrer. Probleme, die in Amerikanischen Gebieten beobachtet wurden sind: Grundbesitzer vs. Erholungssuchende, private vs. kommerzielle Nutzung, motorisiert vs. nicht-motorisierte Besucher und sanitäre Themen (derzeitige Nutzer vs. vorangegangene Nutzer).

\section{Management Praktiken und Methoden}

Übergreifende Ergebnisse ergaben die Erklärungen für „Möglichkeiten zum Management von Auswirkungen der Erholungsnutzung“ und „Techniken zur Besucherregulierung“. Daher wurden all diese Elemente in einer Kategorie zusammengefasst und als „Management Techniken“ klassifiziert. Die Kategorien, die sich aus diesen Fragen ableiten lassen sind allgemeine Praktiken unter welchen alle speziellen Beispiele klassifiziert werden können. Diese Praktiken, wie zum Beispiel die Vermeidung ökologisch sensibler Gebiete, und Bildung und Information für die Besucher im Vorhinein, werden in dieser Fragerunde in Frage 6 behandelt.

Nochmals vielen Dank für Ihre Teilnahme! 


\section{Appendix G}

\section{Introductory Email for Austrian Participants}

Liebe Teilnehmer und Teilnehmerinnen der Delphi-Befragung!

Die Zeit fuer die zweite Runde ist gekommen! Zuerst möchte ich mich bei Ihnen fuer Ihre Mithilfe bei der ersten Runde meiner Forschungsarbeit bedanken. Diese Studie befragt wenige Experten, benötigt aber viel an Information, deshalb ist Ihre weitere Teilnahme so wichtig.

Ich habe die Ergebnisse der ersten Runde zusammengefasst und werde sie Ihnen mit den Fragen der 2. Runde naechste Woche zusenden. Lesen Sie sich bitte die Definitionen und Beobachtungsergebnisse genau durch, damit ein gemeinsames Grundverständnis vorhanden ist. Die Absicht der vorherigen Runde war es, allgemeine Verwaltungskonflikte und Besuchermanagementtechniken zu identifizieren. Die Absicht dieser Runde ist es nun, die Bedeutung dieser Elemente zu bestimmen.

Ich werden Ihnen die Fragen am Dienstag, dem 6. April, zuschicken und hoffe, dass Sie diese innerhalb von zwei Wochen (20. April) beantworten können.

Ich freue mich schon auf Ihre Antworten!

Vielen Dank!

Jessie Meybin

Graduate Student Assistant

WVU: Division of Forestry 


\section{Appendix H}

\section{Introductory Email for U.S. Participants}

Greetings Again from a Warm West Virginia!

The time has come for the second round of questions in our Delphi Study on managerial conflicts and techniques! First of all, we would like to thank you again for participating in the study and reiterate how significant the response rate is for this kind of qualitative research that illicits a big amount of information out of a smaller number of respondents. Your part in this study is essential, and therefore heavily appreciated.

The objective of the first round was to identify and catagorize the common conflicts administrators face, and techniques they use, managing visitors in their area. The objective of the second round is to determine the level of significance of these identified elements. There will not be as many open-ended questions as were in the first round. A summary of the results from the first round will be sent to you along with the second set of questions in two weeks. Please read through the general observations and definitions provided, so the collected results will be more standardized with everyone on the same page (literally and figuratively ;p).

You will recieve the questions on Wednesday, the 6th of August, and we would like them back after two weeks again, on the 20th. I hope that this email finds you well and look forward to more of your insight!

Talk to You Soon!

Jessie Meybin

Graduate Research Assistant

WVU: Division of Forestry

jmeybin@gmail.com 


\section{Appendix I}

\section{Example of a Reminder Email for Non-Respondents}

An die in dieser Studie teilnehmenden Ressourcen Manager:

Vielen Dank, dass Sie an der ersten Runde dieser Studie teilgenommen haben! Dies ist die letzte Fragerunde. Ihr Beitrag ist uns sehr wichtig, da jede Frage in beiden Fragerunden von denselben Experten beantwortet werden muss.

[To the Resourse Managers Participating in this Study: Thank you for your participation in the first round! This is the last round of questions. Your contribution is very important to us, especially in the second round where every answer given is equally significant!] 